\title{
Neo-liberalism and the Rise of Radical Economism
}

\author{
By André Munro, B.A.
}

\author{
A thesis submitted to \\ the Faculty of Graduate Studies and Research \\ in partial fulfillment of \\ the requirements for the degree of \\ Master of Arts
}
Department of Political Science
Carleton University
Ottawa, Ontario
Canada

(C) André Munro 2006 


$\begin{array}{ll}\begin{array}{l}\text { Library and } \\ \text { Archives Canada }\end{array} & \begin{array}{l}\text { Bibliothèque et } \\ \text { Archives Canada }\end{array} \\ \begin{array}{l}\text { Published Heritage } \\ \text { Branch }\end{array} & \begin{array}{l}\text { Direction du } \\ \text { Patrimoine de l'édition }\end{array} \\ \begin{array}{l}\text { 395 Wellington Street } \\ \text { Ottawa ON K1A 0N4 } \\ \text { Canada }\end{array} & \begin{array}{l}\text { 395, rue Wellington } \\ \text { Ottawa ON K1A ON4 } \\ \text { Canada }\end{array}\end{array}$

Your file Votre référence ISBN: 978-0-494-18287-1 Our file Notre référence ISBN: 978-0-494-18287-1

NOTICE:

The author has granted a nonexclusive license allowing Library and Archives Canada to reproduce, publish, archive, preserve, conserve, communicate to the public by telecommunication or on the Internet, loan, distribute and sell theses worldwide, for commercial or noncommercial purposes, in microform, paper, electronic and/or any other formats.

The author retains copyright ownership and moral rights in this thesis. Neither the thesis nor substantial extracts from it may be printed or otherwise reproduced without the author's permission.
AVIS:

L'auteur a accordé une licence non exclusive permettant à la Bibliothèque et Archives Canada de reproduire, publier, archiver, sauvegarder, conserver, transmettre au public par télécommunication ou par l'Internet, prêter, distribuer et vendre des thèses partout dans le monde, à des fins commerciales ou autres, sur support microforme, papier, électronique et/ou autres formats.

L'auteur conserve la propriété du droit d'auteur et des droits moraux qui protège cette thèse. $\mathrm{Ni}$ la thèse ni des extraits substantiels de celle-ci ne doivent être imprimés ou autrement reproduits sans son autorisation.
In compliance with the Canadian

Privacy Act some supporting forms may have been removed from this thesis.

While these forms may be included in the document page count, their removal does not represent any loss of content from the thesis.
Conformément à la loi canadienne sur la protection de la vie privée, quelques formulaires secondaires ont été enlevés de cette thèse.

Bien que ces formulaires aient inclus dans la pagination, il n'y aura aucun contenu manquant.

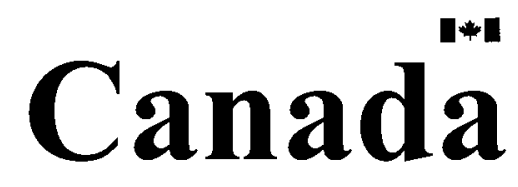




\section{Acknowledgements}

À Geneviève pour son amour, son support; je n'aurais pas pu emprunter ce chemin seul. Je la remercie aussi pour sa patience, ses corrections et ses suggestions qui ont amélioré grandement la qualité de ce mémoire. I am also indebted to Professor Maben W. Poirier for having shown me the limits of ideology and philosophy as a way of life. To my teachers and mentors Professor Host Hutter, Dr. Herminio Meireiles Teixeira and Professor Maben W. Poirier for having giving me the passion of political theory and opened the way for a vocation. A special thanks to my supervisor Professor Tom Darby and my readers Professor Alan Hunt and Professor Geoffrey Kellow. Merci par ailleurs à Diane Breton pour ses conseils judicieux et son ouverture à discuter avec un novice sans condescendance aucune. I am also grateful for the support of the Fonds Québécois de Recherche sur la Société et la Culture, the Ontario Graduate Scholarship and the Social Science and Humanities Research Council for having supported this thesis project. 


\section{Thesis Abstract}

By contrasting neo-liberalism with liberal and more succinctly classical-medieval thought, this thesis expose this movement as a form of radical economism, the unlimited application of economic rationality to an increasingly larger field. Particular attention is given to the writings of Adam Smith and the Chicago School of Economics to demonstrate that neo-liberalism is based on a totalising and rationalistic principle absent in the classical form of liberalism. Inspired by Foucault and Arendt, this thesis approaches neo-liberalism both as an economistic mode of government and as the erosion of the political sphere of existence. 


\section{Table of Contents}

I. Introduction 2

II. Looking to another age: the ancient primacy of the political 8

III. Classical liberalism: in search of balance 24

IV. Neo-liberalism and the totalisation of the economic 67

V. Neo-liberal governentality: the market as a matrix of order 99

VI. The retreat of the political sphere of existence: consumer society $\quad 120$ and the return of homo laborans.

$\begin{array}{ll}\text { VII. Conclusion } & 144\end{array}$

$\begin{array}{ll}\text { VIII. Bibliography } & 150\end{array}$ 
He who reads the inscrutable book of Nature as if it were a Merchant's Ledger is justly suspected of having never seen that Book, but only some School Synopsis thereof; from which if taken for the real book, more error than insight is to be derived.

Thomas Carlyle 


\section{Introduction}

In our age of advanced economic globalisation, understanding the moving boundary delimiting the political from the economic is arguably more important than ever. While many scholars and social activists have highlighted the growing power of global corporations and the powerlessness of national governments in matters of trade, much less attention has been devoted to the relation between the political and economic spheres as distinct modes of existence.

All history and political science students are aware that boundaries are displaced over time and that their alteration, however small it is, affects the whole entity they delimit. This is of course true for geo-political boundaries, but equally for the limits defining the public and political spheres. In this sense, this thesis presents a reflection on the actual state of that boundary - or the absence thereof - separating the political from its most potent contemporary competitor, the economic domain. By contrasting neo-liberal thought, with special attention to the writings affiliated with the Chicago School of Economics, with early liberalism and more succinctly classical-medieval thought, this thesis exposes neo-liberalism as a form of radical economism, which is the unlimited application of economic rationality to an increasingly larger field. ${ }^{1}$ Whereas classicalmedieval thought understood the political as superior and primary to the economic and whereas earlier forms of liberalism limited the market to one sphere of human activity amongst others (culture, religion, etc.), neo-liberalism enlarges the field of economy to encompass all social interactions and elevates economic rationality as the principle by

\footnotetext{
${ }^{1}$ Neo-liberalism is not to be confused with radical economism, of which it is merely one of the clearest expressions. We could have analysed other forms of this phenomenon like orthodox Marxism, in which the superstructure follows in a direct and quasi-mechanical manner the movement and direction of the economic structure.
} 
which all reasonable behaviours must be guided. Especially inspired by the writings of Arendt and Foucault, we thus wish to demonstrate that neo-liberalism represents far more than an anti-social ideology, a policy of cuts to social programs, a minimalist vision of the state or the simple repetition of Adam Smith's Liberalism. It represents, in short, an economistic form of government and the retreat of political existence. Because of the limited length afforded by a master thesis, this analysis will focus on the comparison between early liberalism and neo-liberalism. In this perspective, the writings of Adam Smith and the Chicago School of Economics will be the main primary sources examined.

This analysis will be carried out at two different levels. With Foucault as our first guide, neo-liberalism will be analysed as a specific gouvernmentalité (a rationality and technology of power) based primarily on an economic subject of individual choice (homo oeconomicus) and the ubiquitous character of the market. We will see that, contrary to pre-modern forms of sovereignty and to classical liberalism, neo-liberal governmentality is a rationalistic and totalising mode of power. The economic subject is encouraged to evaluate everything in terms of consumer-based rationality and behave accordingly. Secondly, Arendt's theorisation of the expansion of the Social will helps us uncover neoliberalism as an advanced stage in the depreciation of the political at the profit of the economic. Notwithstanding their differences and disagreements, it is believed that both theorists help us understand, through Foucault's concept of bio-political governmentality and Arendt's portrait of homo laborans, that radical economism represents the elevation of 'mere life' $(z o \bar{e})$ as the ultimate object of government.

Epistemologically, this thesis draws mainly on the genealogical and phenomenological approaches. On the one-side, we will avoid presenting political action, the political sphere or the political subject as transcendent essences immune from power 
and change. Although our study is based on a quasi-ontological conception of the political, it recognizes that its form, its boundary and its content is shaped by power relations. Indeed, by demonstrating the demotion of the political in favour of an economistic mode of government, this thesis highlights the changing nature of these categories. On the other side, we will present in the tradition of existential phenomenology the political and the economic realms and subjects as spheres of human activities and modes of Being-in-the-world that are revealed to our collective consciousness. Even though they represent essentially contested realities, these categories and subjectivities are important as they affect the limits and possibilities of human life and self-understanding. Such an anti-essentialist interpretation does not mean that categories such as 'the political' and 'the economic' are only grammatical entities. As Pécharman explains, the political is real although its reality is not a given, it is a reality that is constructed in the performance of speech and action. ${ }^{2}$ As we will see with Arendt, political activity itself reveals to consciousness the existence of a shared world. The economic and the political are not to be taken as natural entities but as spaces of possibilities, spheres of existence rendering possible certain modes of Being-in-the-world and Being-with-others and closing the door to others. To understand such categories as spheres of existence is not to fall into complete relativism but simply to understand that pure idealism and metaphysics are themselves escapes from the political. Human existence is political precisely because this existence is itself in question ${ }^{3}$ and the limits

\footnotetext{
${ }^{2}$ Martine Pécharman, "L'idée du politique," in Denis Kambouchner (ed.), Notions de Philosophie, III (Paris: Gallimard, 1995), 92.

${ }_{3}^{3}$ Martin Heidegger, Being and Time (San Francisco: Harper San Francisco, 1962), 32.
} 
of the political and the economic, however uncomfortable such a political sensibility might be, remain open to speech and action.

Moreover, the promotion of the economic subject and consumer-citizen over the political actor will be interpreted as reflecting different strategies to form and promote a well-governed subject. The terrain of the political and the economic are also spaces invested with power and organised in terms of order. It is therefore important to show that the 'retreat of the political' does not mean that power and government disappear. In the language-game of neo-liberalism, the reconfiguration of what is 'economic' is associated with a new form of government, one pushing to its out-most limit the market as a matrix of spontaneous order and the ideal of "governing at a distance". ${ }^{4}$ Indeed, it is because the economic domain is govermentalised, passing from the realm of production and services to a equilibrating and ordering force, that economics can pretend to replace politics as the master science from which standpoint all other realities are ordered and hierarchised.

Finally this thesis attempts to open up a dialogue between the Arendtian and Foucauldian perspectives on the modern position of the political. While it could appear that the two authors disagree on whether the political terrain has eroded or has on the contrary expanded, we propose that their theories have a lot in common in their descriptive dimension and that a dialogue can be engaged between them after distinguishing what they mean by politics. Hence it is not seen as a contradiction to affirm at the same time that the political has retreated and that the possibilities to critique the exercise of power in private and public spaces have increased and have been democratised.

\footnotetext{
${ }^{4}$ Peter Miller and Nikolas Rose, "Governing economic life," Economy and Society 19, No. 1 (1990): 9.
} 
In our opening chapter, we return briefly to the relation between the economic and political spheres as idealised in Greek antiquity and the European Middle Ages. The pretension of this short chapter is certainly not to give the readers an accurate summary of more than two thousands years of history. Simply, it is hoped that by describing these epochs in a broad outline and by contrast, we can make visible the transformation occurring and the radicalism of this change. As a contrasting standpoint, the classicalmedieval period can make us realise that while classical liberalism is quite moderate in comparison to neo-liberalism, it still represented an advance of economism in the larger scheme of history.

Our second chapter, focusing on the advent of political economy and the thought of Adam Smith, draws a portrait of the political/economic relation as conceived by classical liberalism. Particular attention is given to the moderate and balanced character of classical liberalism. As we will see, classical liberalism seeks to protect the domain of the economic from the ignorance of the sovereign but does not generalise its logic to all reality. Educated in the classical tradition, an author such as Smith still believed in the mere life/good life distinction and considered the tranquillity of ethical life as superior to the accumulation of wealth.

The three last chapters all analyse, from different angles, neo-liberalism and reveal it as a form of radical economism. The distinction between those chapters lies in the perspective adopted. In the third chapter, a general overview of neo-liberalism is given to make explicit its radicalism. Studying the rupture and continuity between the Austrian School of Hayek and the Chicago School of Friedman, we describe how the market is projected as the perfect matrix of order and how the scope of the economic is expanded in a rationalistic and totalising manner. In the fourth chapter, neo-liberalism is approached 
from the angle of power. In the light of Foucault's recently published lectures at the College de France, neo-liberalism can be presented as a mode of govenmentality, a mode of power primarily based on the self-governance of maximising subjects. Although himself hostile to such grand categories, we believe Foucault's thought can help us decipher how economism claims to organise and govern social life in its entirety and therefore replace politics as the art of living together. Finally, the fourth chapter turns to Hannah Arendt and argues that radical economism represents what some have called the 'retreat of the political'. Taking the political seriously, Arendt devoted most of her life to exploring the meaning of the vita activa. Although we contest the rigidity of her categories, we believe her account of the victory of the homo laborans remains an accurate description of consumer society and the flattening of meaning which accompanies radical economism. In an Arendtian spirit, we wish this thesis to stand not as a resignation towards the end of politics but rather as a call to a collective awakening and action. Although very different, we believe the sociological analysis of neo-liberalism as an economistic mode of government and the more philosophical interpretation of radical economism as a retreat of the political can complement each other. Foucault's analysis examines the neo-liberal model of governmentality while Arendt's writings illustrate the consequences of this movement in terms of existential meaning; both approaches are welcomed to understand a movement that pretends to have found in the economic sphere a source of both order and meaning. Emphasising the rupture of neo-liberalism with the traditional primacy of the political over the economic as well as with classical liberalism's spirit of moderation and pluralism, this thesis will try to demonstrate the radicalism of this movement, give an idea of the immensity of the space colonised over time by the economic, and explain the significance of its new pretension to primacy. 


\section{The classical primacy of the political}

From Classical Greece to the end of the Middle Ages, the division and the superiority of the political over the economic is a fact taken as obvious. Whether it is considered at the service of the pólis, the common good, or the prince, economic life was integrated into the norms and culture of the community and consistently understood as subservient to the later. ${ }^{5}$

In the classical pólis of the $\mathrm{IV}^{\text {th }}$ and $\mathrm{V}^{\text {th }}$ century B.C., a period when political consciousness gains some autonomy over religion ${ }^{6}$, the economic, in both its private and collective dimensions, remains completely integrated, dependant and subjected to the life of the community as a whole. As we have learned from the substantivist school of political economy and scholars such as Michael Polanyi and Moses Finley in particular, antique societies did not approach the economic as an independent sphere or as a theme warranting study on its own. On the contrary, topics related to the economic were always studied in relation to an end considered of a higher nature than household management or profit acquisition. ${ }^{7}$ When, for instance, Aristotle discusses household management (oikonomia) or commerce (money economy, chrematistike), the underlying message is really about the proper positions the citizen must adopt towards his family and belongings, as well as the unnatural character of striving for profit as an end in itself. ${ }^{8}$

\footnotetext{
${ }^{5}$ André Piettre, Histoire de la pensée économique et analyse des théories contemporaines (Paris: Dalloz, 1966), 1-4.

${ }^{6}$ On this question the classical Greek pólis differs from its archaic counterpart. See Pauline Schmitt-Pantel, "Collective activities and the Political," in Oswyn Murray and Simon Price, The Greek City, From Homer to Alexander (Oxford: Clarendon Press, 1990), 210.

${ }^{7}$ M.I Finley, The Ancient Economy (Berkeley, University of California Press, 1973), 17-20.

${ }^{8}$ Aristotle, The Politics (Chicago: University of Chicago Press, 1985), 44-52.
} 
When the same philosopher analyses economic exchanges and price formation, it is again from the perspective of ethics and politics. As Polanyi and Finley have explained, the absence of an Aristotelian economic theory is not a sign of the Philosopher's lack of knowledge of that 'field' but rather a reflection of the Greek ethos in which economy was never isolated, even conceptually, from the community. In the same spirit, when Xenophon discusses the good management of the oikos, the domain, he designates by this field a reality far larger than the modern concept implies. Besides farming per se, the discussion touches upon a large web of activities and qualities (for instance physical fitness, warrior patriotism or leadership qualities) seen as supporting or arising from the gentleman farmer way of life. ${ }^{9}$ In this sense, the economic is never isolated, even conceptually, from the community. With few possible exceptions, the economy is constantly approached as a secondary subject and always as a mean and not an end. ${ }^{10}$

Not only does the Greco-Roman world has no conscience of the economic as an abstract reality possessing its own dynamics and rationality, but this sphere of existence is also subordinated to it of the political. Again, Aristotle writings can shed some light over this issue, it being widely accepted that the Stagyrite philosopher is more representative of classical Greece thought than Plato or even Xenophon. Aristotle opens one of his most seminal texts, The Politics, by distinguishing ontologically the two spheres of existence, the political from the economic, and by affirming the primacy of the former over the latter. From the onset, the founder of the Lyceum makes clear that political rule is not to be conflated with the management of household or slaves (oikonomia). ${ }^{11}$ The difference

\footnotetext{
${ }^{9}$ Xenophon and S.B Pomeroy, Oeconomicus: a social and historical commentary (Oxford: Oxford University Press, 1994), 129-135.

${ }^{10}$ An exception could be the Pseudo Aristotelian Oeconomicus, see M. I. Finley, Op. Cit., 20-21.

${ }^{11}$ Aristotle, Op. Cit., 35.
} 
between these two realms of activities, Aristotle argues, is of quality and not of quantity. ${ }^{12}$ This ontological distinction arises from two considerations. First, the pólis is prior to the household because it leads to self-sufficiency (whereas the household cannot be sustained on its own). ${ }^{13}$ Secondly, while household management and commerce are engaged in for the need of living, political activity is engaged in for the sake of living well. This hierarchisation of values, understanding the economic as meaningful only as a mean towards political life, is adopted consciously and explicitly as one of Athens's sources of identity. In his famous Funeral Oration, Pericles boasts the primacy of the political as one of Athens's source of pride: "For we alone think that a man who does not take part in the affairs of the city is good for nothing, while others only say he is 'minding his own business'."14 The establishment of the city-state and the activity of politics is thus distinguished from economic activity as a transcendence of necessity management and a leap into political action. One of Aristotle's most famous expressions illustrates cogently the priority accorded to the political: "he who is without a city through nature rather than chance is either a mean sort or superior to man", either an animal or a god. ${ }^{15}$ For many thinkers of Attica, the political emerges directly from our humanity, our capacity of existing as beings of reason and deliberation. To be the one and only animal bearer of the logos signifies far more than simply being able to communicate, for in this predicament we are no different than bees or other gregarious animals. The metaphysical distinction drawn by Aristotle between mere life (zoē) and qualified life (bios) has played a fundamental role in the development of the political consciousness of the West, serving as

\footnotetext{
${ }^{12}$ Ibid., 35 .

${ }^{13}$ Ibid., 37.

${ }^{14}$ Thucydides and P. Woodruff, On justice, power, and human nature: the essence of Thucydides' History of the Peloponnesian War (Indianapolis: Hackett, 1993), 42.

${ }^{15}$ Aristotle, Op.Cit., 37.
} 
a negative standard from which to elevate humanity. As Giorgio Agamben's reading of Aristotle points out, the political appears out of its distinction with the negative standard of mere-life: "There is politics because man is the living being who, in language, separates and opposes himself to his own bare life and, at the same time, maintains himself in relation to that bare life in an inclusive exclusion." ${ }^{16}$ It is not fortuitous that the classical conception of the political understands this realm as higher than the economic since the very existence of the former is predicated on the transcendent position it occupies above what is understood as part of the cyclical and ultimately meaningless zoe .

Although household management (oikonomia) is judged lower than the political, this private facet of economic activity is still a matter of necessity and hence judged as a legitimate activity to engage in. As for the other, profit-motivated, dimension of the economic, what Aristotle refers to as chrematistike, it is looked down with a more severe attitude. In reality, chrematistike is completely antithetical to the ideal of the pólis. In a polity based on patriotism and the self-control of its citizen-soldiers, external commerce represents a potentially subversive activity and an open door on internal strife and chaos (stasis). Not only do merchants entertain suspect relationships with outside forces, commercial activity was also criticised as the slavish reign of appetites over reason, a base and slavish position incompatible with the duties of a citizen. Unlike the nineteenth century English merchants praised as the great captains of industry and creator of wealth or the contemporary encouragement of entrepreneurs as creative leaders, the moneymakers of Antiquity are, at best, tolerated as a necessary evil. Always looked from above, often ridiculed and sometimes even excluded from the public realm or altogether

\footnotetext{
${ }^{16}$ Giorgio Agamben, Homo Sacer: Sovereign Power and Bare Life (Stanford, California: Stanford University Press, 1998), 8.
} 
banished, people living from commerce are stigmatised in a manner similar to today's common perception of prostitutes. ${ }^{17}$

\section{Order-spiritual and material}

The first fundamental reason for the hierarchy of values elevating the political above the economic lies in the need for stability and order, both spiritual and material. In the pólis, politics appears as a solution to the cultural and spiritual crisis experienced after the Peloponnesian War, an active and reflexive participation in the fortification of the 'We'. Partaking in the family religion or believing in the Homeric myths is no longer an adequate answer to the predicament of Socrates's contemporaries. Greek society had emerged out of the ancestral cosmocentric and tribal world-view and the human individual actor and thinker, the anthropos, has gained an unprecedented space of legitimacy and importance. Of course, religion remains a powerful source of meaning and authority, still imbuing all other modes of human activity and existence, including the political. As the death of Socrates reminds us, it is not economics which represented, for politics and philosophy, the contender as the architectonic science, but the religion of the house, the city or those myths shared by most Hellenes. ${ }^{18}$ Economics was not seen as a potent challenger for this position since it did not offer an answer as to the integration of the self and the collectivity. On one side, that of oikonomia, economic space is associated with the family, the tribe, or other such sub-political and un-reflexive units. On the other, that of chrematististike, it represents the self-seeking and ultimately meaningless pursuit of the desires of the 'I'. Unlike this twofold conception of ancient economic space, the

\footnotetext{
${ }^{17}$ Paul A. Rahe, Republics Ancient and Moderns, Classical Republicanism and the American Revolution (Chapel Hill: The University of North Carolina Press, 1992), 58.

${ }^{18}$ On the importance of religion in Classical Greece see Fustel de Coulanges, La Cité Antique, étude sur le culte, le droit, les institutions de la Grèce et de Rome, Vingtième édition (Paris : Hachette, 1908), 1-5.
} 
political possesses the necessary ground to represent an authoritative source of meaning and identity, creating an existential horizon from which to organise social life. While religion, through faith and rituals, serves as a horizon ${ }^{19}$ revealing to the believer its place in the cosmos, the political becomes for the citizen and the city-state an alternative ground or horizon linking dialectically the self and the community. As Strong explains, politics differs from morality, religion or economics in that it represents "the most general response to the simultaneous asking of the two questions, 'who am I' and 'who are we'." ${ }^{20}$ Within the horizon delineated by the political, the 'We' becomes a solution to the question of the 'I'. Yet political existence always remains marked by a tension, never reducible to the group or the individual. In contrast, ancient economic activity is dependent on other realms (in the case of oikonomia) or often regarded as outright unnatural and slavish (in the case of chrematistike). The subordinate position assigned in Greek culture to the economic is also related to an ideal of ethical education for the warrior aristocracy charged with the city's defence and leadership. In this sense it is not only a cultural question but equally instrumental to the survival of the community. In the upbringing and disciplining of young citizens, many dangers are attached to the possession of wealth or the lack thereof. On one side, to be subjected to poverty (ponos) is antithetical to the autonomy and leisure demanded by a citizen's life. One can find a clear exposé of this position in the writings of Demosthenes. For this great orator, ponos brings down the dignity of the free citizen and impedes his capacity for political speech and action: it both compels the citizen "to do many things slavish and base" and makes

\footnotetext{
${ }^{19}$ On the question of the existential horizon, Voegelin's idea of the metaxy might bring some light. Whether cosmocentric or anthropocentric, most ancient societies understood symbolically spiritual activities (religion, philosophy, etc) in such an in-between space, between particular and universal, nothingness and absolute, animality and godliness.

${ }^{20}$ Tracy B. Strong, The Idea of Political Theory, Reflections on the Self in Political Time and Space (Notre Dame: University of Notre Dame Press, 1990), 3.
} 
him "unable to say or do anything. For his tongue will be tied." ${ }^{21}$ On the other side, the search for and possession of riches is looked on with apprehension by the public as it is seen as having dangerous impacts on the citizen's self-esteem, leading to excesses (hybris) and threatening the community with division (stasis). ${ }^{22}$

Furthermore, the priority of the political over the economic is supported by the platonic tripartite division of the human soul (reason/spirit/appetites) and its transcendence of animality. Although generally not the most representative author of Classical Greece, Plato's Republic's tripartite order mirrors the hierarchy that most believed must reign in well-governed poleis and human souls. At the beginning of the description of the "City of Speech", Socrates lays down the foundations of a city of necessity, a 'healthy' city erected on the labour and work of farmers, craftsmen, traders, and all other professions required by the life and reproduction of the community. However, an aristocratic spirit is in the room, one who refuses to let the city be reduced to the fulfilment of mere-life and the numb satisfaction associated with corporeal satiety. Although they live in houses and divide their labour, the inhabitants of the 'healthy city' are closer to nature than to culture, sharing animal appetites but no distinctly human longings. The honour-loving and erotic Glaucon wants more; he has tasted the richness of life and its overflowing dimension. With sarcasm, he urges Socrates to go beyond the first city: "If you were providing for a city of sows, Socrates, on what else would you fatten more than this?"23 Reflecting this conception of natural order, the political must

\footnotetext{
${ }^{21}$ Demosthenes, Cited in Paul A. Rahe, Op.Cit., 38.

${ }^{22}$ Ian Morris, "The Community Against the Market in Classical Athens," in Colin M. Duncan and David W. Tandy (eds.) From Political Economy to Anthropology, Situating Economic Life in Past Societies (Montréal: Black Rose Books, 1994), 57.

${ }^{23}$ Plato, The Republic, trans. Alan Bloom, second edition (New York: Basic Books, 1968), 49.
} 
reign on the economic as reason must, with the help of the spirited part of the soul (thymos), keep control over our longing, appetites, and desires.

The primacy of the political over the economic is hence not solely a philosophical and institutional question, but parallels a model of the well-governed self, an ethic of selfmoderation and restraint thought to be central to the order of the pólis. The relation between the primacy of the political over the economic and the correlate regime of the soul presented in The Republic is made even more explicit in The Laws. Not content with limiting politics to the constitution of poleis, the Athenian stranger here discusses with Kleinias the Cretan and Megillus the Spartan the order and hierarchy that must exist in the souls of the good citizens for a polity to be just and for its laws to be rooted in virtue. In this journey that will lead them to the elaboration of a new colony's laws, the three discussants begin by laying down the foundations of stability, order, and virtue in what might constitute the city writ small: the regime of the soul. Before attending to the disorder, wars, and strife arising from human interactions, one must first take care of the inner conflicts that take place in each of us. As in the city, the Athenian points out, there is in the soul of each man a multiplicity of forces fighting for rule. ${ }^{24}$ One does not have to look very far for the cause of civil war, the possibility of chaos looming in every one of us: "there is a war going on in us, ourselves against ourselves." 25 The platonic art of politics is far more ambitious than simply knowledge of political structures and processes; it always begins as an exercise (askesis) in the care of the self and of others, as the "business it is to care for souls." 26 Proposing a ranking of the different goods available to us and separating them in divine and human categories, the Athenian Stranger places

\footnotetext{
${ }^{24}$ Plato, The Laws, trans. Thomas L. Pangle (Chicago: University of Chicago Press, 1988), 5.

${ }^{25}$ Ibid.

${ }^{26}$ Ibid.
} 
wealth as the lowest of them all. ${ }^{27}$ The highest of the divine good, prudence, must, with the help of courage, come to rule over one's passions and appetites. Although classified as a good, the possession of wealth also represents a danger since it, if unleashed, knows no limit of its own and can seek dominion over reason as a tyrant would do over laws and people. Like its god, Pluto, wealth is blind if unguided by prudence. Ideally, the forces of pleasure and appetites must come to accept the leadership of political prudence. For the ancients, one must not negate the legitimate place for material satisfaction or live as an ascetic, but develop a form of 'spiritual gymnastic' in which one gets accustomed to the attraction of desires and uses other psychic forces to limit their ascendancy over the soul. $^{28}$

Although the economic is conceived as distinct and inferior to the political, it would still be a mistake to portray the ancient representation of this divide as absolute. To share the Greek perspective on that question, it would be more appropriate to conceptualise oikonomia as a foundational activity, which, if fulfilled in line with its nature, can offer humans the leisure necessary for higher activities and equip them with ethical dispositions (temperance, rationality, leadership) pre-disposing them for public life. A too rigid separation of the political with other modes of existence and forms of behaviour, like the strict separation public/private adopted by Arendt, risks covering the role played by extra-political activities in the constitution of the public sphere. As demonstrated by Schmitt-Pantel's study of Archaic Greece group-forming activities, collective institutions such as collective hunts and symposiums cannot be understood as completely external to the public sphere even though they clearly belong to the private.

\footnotetext{
${ }^{27} \mathrm{Ibid} ., 10$.

${ }^{28}$ Ibid., 14.
} 
Although not political activities per se, such undertakings play a major role in the formation of a public and shared experience and in the appearance of relations of equal peerage. ${ }^{29}$ As such, 'private' activities like the banquet, if not political in themselves, can be regarded as positive conditions for the emergence of a common domain (koinon), which space is obviously a sine qua non condition for the political to be possible. Indeed the idea that farming is closely related to the development and preservation of civic virtue and a sense of belonging to the political community is an idea that survives more than a millennium. ${ }^{30}$ We find this portrayal of the gentleman farmer as the occupation most conducive to citizenship in classical writings such as Xenophon's Oeconomicos. From the defence of the city to its management, the earth is said to provide important qualities for the education of a good citizen. Xenophon goes so far as to states that: "The man who said that farming is the mother and nurse of the other arts spoke truly." ${ }^{31}$ To represent ourselves graphically the positions occupied by these two spheres of existence, one should hence think of not two separated and opposed circles but of two partly overlapping circles. Oikonomia, in opposition to the unattached and hence unpatriotic activity of chrematistike, is thought as an important pre-condition for the emergence of a healthy political domain and sense of civic duty.

It would be easy for us modern readers to associate the classical primacy of the political with a primitive economy or with a lack of consciousness of commerce benefits. Yet, contrary to this perception, the habitants of Ancient Greece are much aware of the

\footnotetext{
${ }^{29}$ Pauline Schmitt-Pantel, "Collective Activities and the Political in the Greek City," in Oswyn Murray and Simon Price (eds.), Op. Cit., 200-201.

${ }^{30}$ Defenders of the old aristocratic ethos like Lord Bolingbroke will later base their critique of the rising commerce and nascent industrial revolution on this long accepted road leading from the private domain to leadership in the affairs of the commons. Isaac Kramnick, Bolingbroke and his Circle, The Politics of Nostalgia in the Age of Walpole (Cambridge, Massachusetts: Harvard University Press, 1968), 73-83.

${ }^{31}$ Xenophon and S.B. Pomeroy, Op. Cit., 133.
} 
necessity of wealth and of the fruits of commerce and trade, and Athens, its most politically conscious city-state, is also an important commercial hub. The Piraeus acts as an entry point for the whole region and beyond, as well as the departure gate for important quantities of wine, oil, decorated jars, and silver. ${ }^{32}$ In the classical period, commerce expands significantly and, albeit Greek xenophobia, extends to the so-called 'barbarians'. Indeed, this movement of resources coincides with increased interactions with different cultures and foreign mentalities, which, whatever the resistance, clearly affects philosophy and politics. As different authors have noted, it is not fortuitous that the most seminal book on justice of this age, Plato's Republic, opens with Athens's Piraeus as its background stage. It is particularly revealing that Socrates's relentless quest for the meaning of the Good and the just ordering of the soul begins in this book by recognising foreigners' deeds. ${ }^{33}$ Of course, Socrates is not nor could have been a modern cosmopolitan man. Yet his boundless love of wisdom seeks the logos where he sees it, breaking civic boundaries if needs be. While the Greek pólis was proud of its identity and generally weary of foreigners, Socrates recognises that any cogent reflection on one's community values and institutions must reckon with others and be enriched by the experience of cultural difference, whether from the lessons of the past or from others. In that sense, the relative opening of Athens' doors to commerce has certainly been a factor in the evolution of its culture and its political institutions. ${ }^{34}$ At the very least, it paradoxically gave its citizens a negative standard from which to compare themselves and

\footnotetext{
32 It is important to note that although Lévy brings important facts about Greek trade volume and contents, we do not share his rather weak analysis of the attractiveness of trade for Greeks or his anachronistic comparison between the Greek pólis and the $19^{\text {th }}$ century commercial powers. See Jean-Phillippe Lévy, The Economic Life of the Ancient World, trans. John G. Biram (Chicago: The University of Chicago Press, 1967), 24.

${ }^{33}$ Plato, The Republic, trans. Alan Bloom, second edition (New York: Basic Books, 1968), 3.

${ }^{34}$ One can note the constant comparison between Athens and Sparta in classical political philosophy.
} 
affirm their uniqueness. The very moral charge launched by philosophers of Classical Athens against the perceived dangers of commerce might well be a reaction to the increased place occupied by this activity and the rise of a merchant class. ${ }^{35}$

\section{The Middle Ages: the minor arts of oikonomia}

Thought-out the Middle Age, the subordination of the economic is perpetuated by Christian doctrine. In its theorisation of the purpose of the state, medieval philosophy stands in continuity with Plato and Cicero. The primary task of the 'City of man' is the maintenance of justice, without which no commonwealth can endure. ${ }^{36}$ However, one significant change that occurs in medieval economic thought is that the economic is no longer negatively contrasted with the political but with the divine order of nature. Before the Fall, it is believed, there existed no property, no sovereign, nor politics nor economics. ${ }^{37}$ In this sense, both sovereignty and economic activity are considered parts of human law in contrasts to divine law and unfortunate yet necessary predicaments of the human fallen condition. True, the political is still considered higher than the economic, since the sovereign replicated on earth the sovereignty of God and has his authority derived from divine will, but politics is nevertheless dethroned as the master science by theology.

Furthermore, if both political and economic activities derive their principles of action from the virtue of prudence, political prudence is judged higher because more universal in its scope than domestic prudence (aiming at the common good instead of the

\footnotetext{
${ }^{35}$ Although I consider problematic his use of the word capitalism to characterise (even if partially) classical Greece, Trever may be correct on this point. See A. A. Trever, A History of Greek Economic Thought (Chicago: The University of Chicago press., 1916), 21.

${ }^{36}$ Ernst Cassirer and C. W. Hendel, The Myth of the State (New Haven: Yale University Press, 1974), 97.

${ }^{37}$ Diana Wood, Medieval Economic Thought (Cambridge: Cambridge University Press, 2002), 17.
} 
individual good). ${ }^{38}$ Throughout the Middle Age, the economy is hence subservient to the common good of the community and, by extension, to the prince. Private property is generally recognised but riches are considered as entrusted on the upper class as stewards of a property belonging to mankind as a whole. ${ }^{39}$

This hierarchy is made evident by the legislation of the crown and the church over economic matters. In stark opposition to today's ideal of free markets, the medieval ideal of a well ordered economic sphere is one of equality of justice in exchanges, instituted through moral and political intervention. Following this ideal, commercial exchanges of goods are regulated with the political evaluation of a just price and, in the domain of financial exchanges, by the prohibition of usury. ${ }^{40}$ The market, far from being a space which should be let free to function on its own, is addressed as a place of vice and corruption. A commentator of the Thirteen Century warns in the following passage his brethren of the danger of the market place for the salvation of their souls:

Sometimes again the lord is defrauded of market dues, which is perfidy and disloyalty....Sometimes, too, quarrels happen and violent disputes... Drinking is occasioned.... Christ, you may note, was found in the market-place, for Christ is justice and justice should be there.... Thus the legend runs of a man who, entering an abbey, found many devils in the cloister but in the market-place found but one, alone on a high pillar. This filled him with wonder. But it was told him that in the cloister all is arranged to help souls to God, so many devils are required there to induce monks to be led astray, but in the market-place, since each man is a devil to himself, only one other demon suffices. ${ }^{41}$

Wishing for this space of temptation to be ordered and regulated, medieval authors acknowledge the sovereignty of the prince on the economic sphere, as the supreme

\footnotetext{
${ }^{38}$ St. Thomas Aquinas, Summa Theologiae (New York: McGraw-Hill, 1974), 35-39.

${ }^{39}$ G. O'Brien, An Essay on Medieval Economic Teaching (New York: Burt Franklin, 1920), 85.

${ }^{40}$ Ibid., 102.

${ }^{41}$ Humbert de Romans, “On Markets \& Fairs (c. 1270)," Internet Medieval Sourcebook (Fordham University), http://www.fordham.edu/halsall/source/1270romans.htm (accessed May 16, 2006).
} 
temporal authority who can order and force justice into trade. ${ }^{42}$ Consider for example the unequivocal position taken by the $14^{\text {th }}$ Century schoolman and chancellor of the University of Paris, Jean Gerson: "In the civil state, however, nobody is to be decreed wiser than the law-giving authority. Therefore it behoves the latter, whenever it is possible to do so, to fix the just price, which may not be exceeded by private consent, and which must be enforced." ${ }^{43}$ The price fixed as law by the prince (pretium legitimum) is ipso facto the price to be considered as just (justum pretium).

The doctrine of the Catholic Church on the proper position of the economic has of course not been static or monolithic. From the age of the apostles, the Church has been the stage of intense debates on the proper stance to adopt towards this very mundane yet ever present plane of existence. Indeed we could not fully understand the advent of modernity and liberalism without taking seriously these transformations in the Christian doctrine on the economic and in particular on the topic of commerce. At the beginning, in the late Roman Empire and the Middle Ages of the Fathers of the Church, not much tolerance is expressed. The early Church is clear and adamant in its rejection of commerce. The Fathers of the Church consider the love of money the root of all evils while canon Eiciens Dominus states that sin permeates most aspects of buying and selling and see little hope of salvation for merchants and of course usurers. ${ }^{44}$ Increased urbanism, the aggrandisement of commerce through the crusades, and the translation of the writings of Aristotle by Albert the Great represented important factors for an increased tolerance towards the economic in the Fifteen Century. Notable contributions to this increased

\footnotetext{
${ }^{42}$ Of course this does not mean that the religious authorities were not also sovereign with regards to the economic domain.

${ }^{43}$ G. O'Brien, Op. Cit., 106.

${ }^{44}$ R. A De Roover, San Bernardino of Siena and Sant' Antonino of Florence; the two great economic thinkers of the Middle Ages (Boston: Baker Library Harvard Graduate School of Business Administration., 1967), 10.
} 
toleration towards commerce and the economic are San Bermardino of Siena and San Antonio of Florence who, following St-Thomas Aquinas and John Duns Scotus, recognise economic activity as respectable insofar as it serves the commonwealth. ${ }^{45}$ These thinkers relativise or negate the difference of virtue separating trade from other mundane activities but continue to approach the economic realm from an ethical perspective and to prioritise the political community.

If we take Athens as a standard of comparison, medieval thought still represents an expansion of the economic realm. One can argue that the Middle Ages brought closer the economic (as oikos) and the political with the normalisation of the monarchical form of rule, a model, we have to remember, where the sovereign rules on his kingdom as on his house and as a pastoral figure. Although compared positively against tyranny, both monarchy and despotism are essentially regarded as economic forms of rule. ${ }^{46}$ The main reason why monarchy is regarded morally superior to tyranny lies in the different directions these economic forms of rule take: personal or collective. In one case, the king stands as a benevolent father figure who acts lawfully with the good and aggrandisement of his kingdom in mind. In the other case, power knows no boundary at all and follows only the private interest of the tyrant. While the king's will, legitimated on the basis of reason and justice can still be presented as partly political, the tyrant's will is the upmost expression of the reign of appetites over reason and therefore the classical experience of the economic rule in its most primordial form. ${ }^{47}$

\footnotetext{
${ }^{45}$ Ibid., 10-16.

${ }^{46}$ Leo Strauss and others, De la tyrannie; suivi de, Mise au point ; ainsi que de la Correspondance Leo Strauss-Alexandre Kojève (1932-1965) (Paris: Gallimard., 1997), 60.

${ }^{47}$ The virtuous manager of the oikos, the paternalist king, can be said to master this art and his belongings. On the opposite, the tyrant is totally controlled by the economic domain, in his case all forms of appetites and passions he follows slavishly. See Strauss's comparison of Xenophon's Oeconomicus and his' Hiero. Ibid., 60 .
} 
Nevertheless, it should be clear that although gaining ground, the economic remains, in the Middle Ages, subordinated to the political. Since human law is formulated by the will of the sovereign, this relation (political rule as rule of the sovereign house) is subservient to sovereignty and does represent an economistic form of government or the autonomy of the economic realm as found in the liberal practice. While in comparison with the agonistic and honour-loving public space of the agora the possibility of genuine political life was dramatically affected by the rise of empires and the normalisation of the monarchical form, the primacy of the political as the bene vivere nevertheless survived in the more corrupted form of kingly sovereignty. 


\section{II}

\section{The crisis of modernity and the search for meaning and order}

With the advent of modernity, the perception of the relation between the economic and political spheres of existence arguably underwent its most dramatic reversal. The rise of the merchant class, the Christian reformation and the scientific revolution are some causes behind the transformation of these categories, the boundary separating them and their relative hierarchy. As we will see, the upheavals characteristics of early modernity and the Enlightenment period in particular brought about a crisis of transcendence and a valorisation of immanentist foundations for government. ${ }^{48}$ This reversal occurred both with regards to the source of meaning and the source of order. From a largely uninteresting domain in need of management and limits, the economic became the mirror of the most important natural laws, a space offering answers as to what is and what should be done. This chapter, both theoretical and historical, analyses classical liberalism and the new field of political economy as answers to this crisis.

While during the preceding ages the economic was always subordinated to the political as a mean towards the ethical telos - the good life - of the community, the prince or legislator will now be encouraged to ground and direct his governance on the economic or other natural mechanisms or laws. If classical liberal thinkers diverged in opinions concerning strictly economic forces like self-interest or the invisible hand of the market, all turned to the hitherto rejected realm of mere-life $(z o \bar{e})$ for stable sources of meaning and for symbols surviving the modern attack on traditional sources of authority. As we will see, the immanentist sources of authority which will be proposed by Enlightenment

\footnotetext{
${ }^{48}$ We here prefer to use the term immanentist instead of immanent to highlight the fact that concepts like individual, population, nation, market, are still metaphysical.
} 
thinkers and the new economists are diverse, from the population-mass to the individual bearer of interest and all the way to theories of the moral sense. Nevertheless these thinkers all share a common scepticism towards political rationality and elevate interests, passions and other affects or forces of nature as the primary principles of organisation and behaviour. $^{49}$ As Teixeira explains, the displacement of the common good from civic virtue to bio-politics was advanced by thinkers such as Hobbes who traced back the origin of the state not to our longing for a moral excellence and the good life but to the human appetites and fears we all share. ${ }^{50}$ Indeed, the philosophical anthropology of Locke and Hobbes reflects this reversal, human behaviour and government being based on the ineluctable and natural law of self-preservation. Unfortunately, the scope of our inquiry does not allows us to elaborate on the intellectual foundations behind this teleological reversal nor does it gives us the leisure of a close or exegetical reading of the major thinkers such as Hobbes and Locke leading to this new configuration of the relation between $z o \bar{e}$ and bios. It is clear however that the disembedding of the economic from the polity and its elevation as a source of governmental meaning and order would not have been possible without the focus on these laws of nature.

The modern crisis of transcendence thus devalues the old sources of meaning and order. Meaning and order are only separable conceptually and a crisis of meaning inevitably leads to the erosion of the bounds holding the community and the self together. The old chain of Being put into question by the new cosmology, all transcendent symbols and claims of political legitimacy, including the categorisation of the political as the

\footnotetext{
${ }^{49}$ When thinkers like Hutcheson speaks of morality, the cause of morality is sought is the human as animal instead of the human as political or existential animal. Morality then exists but is an expression of a sense not fundamentally different than the sense of smell.

${ }^{50}$ Herminio Meireles Teixeira, The Sovereignty of Governed Populations: An Inquiry into the Displacement of the Common Good in Modern Political Thought (PhD diss., Ottawa: Carleton University, 2002), 70.
} 
realm of the common good, civic excellence and the space of transcendence of animality, are now seen as arbitrary and too shaky foundations for government to be justified upon. As the economic has been earlier criticised as a source of factions, the political now is.

Ironically, the desacralisation of nature might be one of the main reasons for the new role of mere-life as the immanent telos of government. When nature starts to be understood as nothing more than matter into motion, it both denigrates it and elevates it as the only terrain entirely knowable to humans. ${ }^{51}$ When Hobbes deconstructs the Aristotelian four causes of Being and keeps only two, life is simplified as a standalone machine of which the state is but a Promethean replica. ${ }^{52}$ The question is not to know if Bacon or Hobbes were unconscious atheists: the God or pan-psyche that Enlightenment thinkers believed in no longer required the primacy of the political over the economic, only of human power over nature. In other words, the existence of politics was no longer a sign of our part-animal part-divine nature but on the contrary the institutionalisation of our mundane longings: fears, appetites, passions, preservation.

Setting the stage for the demise of the old politico-moral order are foundational events like the Reformation and the Scientific Revolution. The Reformation critique of natural theology combined with the crisis of transcendence fostered by the Copernican Revolution destroyed the point of rest of the scholastic-medieval world-view.

Previously, within the orthodox Christian framework, the raison d'etre of the prince and of his temporal power (the causa portandi gladium) is the eradication of evil in the world. ${ }^{53}$ Empowered by the grace of God, the sword of the prince is blessed with

\footnotetext{
${ }^{51}$ Francis Bacon, The New Organon (Cambridge: Cambridge University Press, 2000), 45.

${ }_{53}^{52}$ Hobbes, Leviathan (Indianapolis: Hackett, 1994), 3.

${ }^{53}$ Walter Ullman, Principles of Government and Politics in the Middle Ages (London: Methuen \& Co, 1961), 64 .
} 
divine legitimacy. The sacred science and authority which can determine the identity of that evil is however beyond the scope of temporal forces and belong solely to the pope. ${ }^{54}$ The Reformation represents a radical challenge to the Aristotelian-Thomistic order and by extension to the primacy of the political over the economic because of its rejection of natural theology's claim to provide the state with a direction and purpose transcending people and things. According to the new preaching of Luther and Calvin, anyone pretending to understand the Lex Aeterna and Naturalis through unassisted reason is committing the sin of pride or, at the very least, overestimating human capacities and downplaying the unintelligible and impenetrable dimensions of Grace. James Moore gives a succinct and clear account of the theological critique behind the Enlightenment rejection of Aristotelian natural law and its replacement by natural rights theories and laws of nature:

The fundamental problem with the scholastic Aristotelian theory of natural law was theological. That theory of natural law supposed that human beings could participate, albeit imperfectly in the Supreme Being, in the mind of God or the eternal law. In Reformed or Presbyterian theology, no such participation was possible. Men and women do not participate in the real presence of God; the presence of God is merely signified. The mind of God is signified to us by revelation; but the same critics insisted that to cite Holy Scripture is "not at all to philosophize. The mind of God is also made known to us by the nature of things. And such knowledge of the divine mind is properly called the natural law. ${ }^{55}$

Politics is not philosophy, yet political action also takes reason as its direction and horizon. At first, the Calvinist demotion of unassisted reason as a path to faith and divine knowledge did not undermine political sovereignty. Indeed, reformist leaders preached God's appointment of earthly rulers and the necessity of obedience. In the

\footnotetext{
${ }^{54} \mathrm{Ibid}$.

${ }^{55}$ James Moore, "Natural Rights in the Scottish Enlightenment," in Mark Goldie and Robert Wokler (eds.), The Cambridge History of Eighteenth-Century Political Thought (Cambridge: University of Cambridge Press, Forthcoming), 299.
} 
long run however the new teaching contradicts the claim of the sovereign to know the Good and displaces the authority and source of knowledge behind state power from theology to the laws and mechanisms of nature. As we will see, political economy emerges out of this scepticism towards traditional sources of authority.

The Copernican Revolution represents the second major event bolstering this crisis and leading to the new autonomy of the economic later secured in classical liberalism. The new cosmology adopted by Copernicus, Bruno and Bacon is based on universalistic principles directly contradicting the traditional order of Feudal Europe. Within this new Weltanchauung, there can no longer be any transcendent ground for truth, no unmoved mover, no high or low ${ }^{56}$. With the Scientific Revolution the fixed centre from which the grand chain of Being was holding on is lost. As the great NeoKantian philosophers Ersnt Cassirer illustrates:

The heliocentric system deprived man of his privileged condition. He became, as it were, an exile in the entire universe. The schism with the Church endangered and undermined the foundation of the Christian dogma. Neither the religious nor the ethical world seemed to possess a fixed center. ${ }^{57}$

But it would take no time for order to be reaffirmed, this time on the basis of a new immanenticised ground of order and meaning. The moderns rediscovered the normalising power and order-generating quality of human passions and appetites, these attractions Plato referred to as the strings of the gods. ${ }^{58}$ More dynamic, the liberal order will try to

\footnotetext{
${ }^{56}$ Ersnt Cassirer and C. W. Hendel, Op. Cit., 132-133.

${ }^{57}$ Ibid., 169.

${ }^{58}$ Plato, The Laws, trans. Thomas L. Pangle (Chicago: University of Chicago Press, 1988), 25.
} 
decipher the underlying laws behind these forces of nature and to base government on their free yet policed interplay. ${ }^{59}$

One has to grasp the measure of the transformation. From a world-view placing the political above the economic, government and morality are now based on pre-political attributes of laws of nature such as self-interest and empathy. Insofar as the classics would have qualified human appetites as belonging to the economic realm, the state is now seen as legitimate insofar as it protects and allows the flourishing of economic activity and zoè in general.

The following paragraphs will reflect on important schools of thoughts and paradigmatic thinkers at the forefront of this historical reversal. By contextualising the appearance of the field of political economy in the perspective of this anxious search for immanent sources of meaning and order, we can better make sense of the rise of prominence of the economic sphere. In the second part of this chapter, we will engage in a close reading of Adam Smith's work. We will see that, unlike neo-liberal radical economism, Smith's conception of the role of self-interest and the place of the economic realm is more nuanced. Placing the emphasis on private morality, Smith seeks to reconcile the commercial city with virtue. If Smith is to be regarded as a paradigmatic thinker of that period, early liberalism must be understood as bearing the inchoate seed of economism without advocating the full autonomy or totalisation of the economic sphere. In relation to the political, it is a clear advance of economism; from the angle of virtue and ethics, the picture is much more equivocal.

\footnotetext{
${ }^{59}$ The contradiction is only apparent. The free interplay of interest, sentiments or even of the moral sense is always preceded by policing, security and order. The physiocrat, liberal, and neo-liberal critiques of state intervention are always limited and relative.
} 


\section{Political economy and the search for a new order}

The first significant school of thought of what has come to be referred to as political economy and which conflates economy and politics is German cameralism. ${ }^{60}$ The advent of cameralism brings about the displacement of the nature and object of politics in one major respect. The source of governmental meaning, order, and direction is now located outside sovereignty in economic reality. By grounding the objective of government in the economic domain and by defining this later category through the concepts of happiness, population and the primacy of agricultural wealth, cameralism relates the end of government to a form of vitalist welfare, a sort of bio-politics. What is encountered as political is now degraded to the level of governmental interventions directed towards economic ends.

The determining position attributed by the cameralist school to the economic realm can be explained by its understanding of the dynamics at work in society as in nature. Sharing the Enlightenment view of the laws of nature, cameralists believe that there exists a fundamental and intrinsic relation between economy, politics and civil society in general. Like Pufendorf, cameralists see all these different human activities as rooted in a natural, pre-political, and pre-societal attribute of sociability (Verkehr). ${ }^{61}$ Considering the two realms as naturally linked, cameralism rejects as baseless any rigid distinction between the logic of the oikos and that of politics. In fact, cameralists often

\footnotetext{
${ }^{60}$ While mercantilism precedes cameralism, it is not a united school of thought and proposes policies rather than a comprehensive worldview. French mercantlilism was in agreement with German cameralism on the enlightened position of the monarch and the need for constant regulations but departed from it on its preference for manufactured goods over agriculture. Since French mercantilism represented a much larger movement and since Adam Smith writings are a direct reaction to it, some readers could wonder the rationale behind the present focus on the cameralists. The reason is that cameralism was much more theoretically articulated on the need for discipline, police, and regulation. One could say that although mercantilism is more significant for the history of economic thought, cameralism is more important for the genealogy of government as a more self-consciously governmental movement.

${ }^{61}$ Keith Tribe, Governing Economy: The Reformation of German Economic Discourse, 1750-1840

(Cambridge: Cambridge University Press, 1988), 29-30.
} 
use the allegory of the patriarch and his household to represent the ruler and the state. The following passage makes explicit this association:

For what is a good Cammer-President or Cameralist if not an experienced, good and prudent Oeconomus or householder. The science of Oeconomie is essential to the Cammer; thus the teachings of Oeconomie is the genuine and proper founding principle upon which the whole state, from the highest to the lowest, rests. $^{62}$

In this perspective, the direction of enlightened governance is no longer grounded in a transcendent source of truth and legitimacy as for instances the platonic idea of the Good (Agathon), Christian salvation or the medieval conception of natural law as derived from eternal law. On the contrary, for cameralists the primary objective of the ruler must be the enhancement and rational administration of the population's welfare. What is here advocated is not political action but economistic state policing. From the cameralist perspective, the sovereign needs no longer to rule his kingdom, but simply to administer things and bodies.

The cameralist state, or police state as Foucault calls it, is by definition economic and without limit. Unlike the liberal governmentality we will later analyse, it does not aim at limiting the ruler's interventions and does not place much emphasis on the actions of individuals. The real actor of the cameralist economic order is the sovereign, while the population represents a "subject mass to be regulated, enhanced, supervised" and not a collectivity of egos. ${ }^{63}$ Moreover, from cameralism's point of view, the fulfilment of human needs cannot be attained through civil society alone. Although human beings

\footnotetext{
${ }^{62}$ J. H. G., Curieuser und nachdencklicher Discurs von der Oeconomia und von guten Oeconomis (n.p., 1713), 14-15, cited in Ibid., 35 .

${ }^{63}$ Ibid., 29.
} 
naturally strive for commodious living, the natural order of growth and civilisation needs the recurring intervention of rational government - through the action of the enlightened sovereign - in order to prevail in a socialised environment. Two major obstacles make necessary the intervention of the sovereign and an applied knowledge of government (Staatswissenschaft). First, society being divided between unequal social orders and social stations, the sovereign must legislates so that everybody behave in line with his or her social station (Standesmäßig) and receive a welfare commensurate to it. ${ }^{64}$ Secondly, individual subjects are seen as either moved by external factors and forces or simply too ignorant to represent a significant source of order on their own. ${ }^{65}$ Profoundly immature, the population is therefore governed as a family; the subjects being like children prone to transgression; they need security and regulations for their own happiness and development. The action of the monarch is needed to re-order, in accordance with natural law, every space which has fallen out of line.

However, theories of an economic natural order such as that of cameralists increasingly problematised population as a space of government and made explicit the limits of sovereignty. The emphasis on population and the application of new technologies of government (statistics, demography, etc.) highlighted the independent and autonomous logic of population. While cameralism seeks to use these technologies to reinforce the model of the family, they inadvertently reveal population as a distinct phenomenon and help to dethrone the family as the primary model of government. As Foucault remarks:

The perspective of population, the reality accorded to specific phenomena of population, render possible the final elimination of the model of the family and

\footnotetext{
${ }^{64}$ Ibid., 31.

${ }^{65}$ Ibid., 29-31.
} 
the recentring of the notion of economy. Whereas statistics had previously worked within the administrative frame and thus in terms of the functioning of sovereignty, it now gradually reveals that population has its own regularities, its own rate of death and diseases, its cycle of scarcity, etc. ${ }^{66}$

In the Polizeistaat theory of German cameralism and the equally enlightened monarch of French mercantilism, no real distinction can be made between the economy and the sovereign or between the good of the sovereign and that of the populace. However, the uncovering of natural economic laws on which these theories are based reveals important limits to the wisdom of the monarch and thus comes to contradict their premises.

It is in this context of growing scepticism towards the wisdom of the sovereign that physiocratic thought replaces cameralism as the prevailing paradigm. Mostly influential in late $18^{\text {th }}$ century France, the économistes as they were also called unite as a school of thought under the intellectual leadership of Louis XV's physician François Quesnay. ${ }^{67}$ While cameralism recognition of the economy as the main source of governmental truth represents one of the fundamental conditions for the emergence of liberal governmentality, physiocratic thought brings forward two other conditions leading to the apparition of classical liberalism: a focus on individual agency and the belief in laissez-faire generated order.

The respective etymologies of the words cameralism and physiocracy can be very instructive. The two names reveal the opposite positions advanced by these movements concerning the knowledge of the sovereign. On one side, the word cameralism is derived from the word camera, denoting the prince's chamber where the cameralist advisor gives

\footnotetext{
${ }^{66}$ Michel Foucault, "Governmentality," in Graham Burchell, Colin Gordon Peter Miller (eds.), The Foucault Effect: Studies in Governmentality: with two lectures by and an interview with Michel Foucault (Chicago: University of Chicago Press, 1991), 99.

${ }^{67}$ H. W. Spiegel, The Growth of Economic Thought (Durham: Duke University Press, 1991).
} 
counsel to the sovereign on public matters. ${ }^{68}$ It connotes the interventionism and statesmanship needed from the prince's court and the trust that is vested in the sovereign as a steward on the commons. On the other side, the word physiocracy, which means rule of nature, was coined to highlight the superiority of the natural order over the human order of the state. ${ }^{69}$ Physiocracy, like cameralism, aims at enlightening the sovereign about the natural order, but stresses the danger of governing too extensively instead of advocating the need for a plethora of regulations.

With the physiocrats, the major problem of rule changes and becomes a concern with the proper limits and boundaries of government. As Foucault explains, the underlying concern shifts from the need to regulate chaos to the need to adjust one's rule to the order of things: "est-ce que je gouverne bien à la limite de ce trop et de ce trop peu, entre ce maximum et ce minimum que me fixe la nature des choses."70 Contrary to the German cameralists, the physiocrats are sceptics about the capacity of the sovereign to mimic the natural order and they consequently defend the principle of individual laissez-faire. ${ }^{71}$ If both cameralists and physiocrats see natural law as the source of government veridiction (the source of the truths on how to govern), Quesnay's followers believe the sovereign too ignorant and incompetent to legislate better than the god-given laws of nature. The following discussion between a French physiocrat and Catherine the Great of Russia illustrates vividly the position of this school:

"Sir, can you tell me the best way to govern the state well?"

"There is only one way, Madame, namely to be just, that is, maintain order and enforce the laws."

\footnotetext{
${ }^{68}$ Ibid., 714.

${ }^{69}$ Ibid., 185.

70 "am I governing well with regards to this limit of too much and not enough, between this maximum and minimum that the nature of things fix to me?' [My translation] Michel Foucault and others, Naissance de la biopolitique: cours au Collège de France (1978-1979) (Paris: Gallimard -Seuil, 2004), 21.

${ }^{71}$ H. W. Spiegel, Op. Cit., 186.
} 
"But on what basis should the laws of a kingdom rest?"

"On one only, Madame, on the nature of things and men."

"Certainly, but if want to give laws to a people, what rule should one follow?"

"Madame, to make laws is a task which God has reserved for Himself. How can man be considered competent to impose laws on being of whom he has no or only imperfect knowledge? And by what right would he impose laws on beings whom God has not placed in his hands?"

"To what then do you reduce the science of government?"

"To the study of the laws which God has so evidently engraven in human society. He created man. To seek to go beyond this would be a great calamity and a destructive undertaking." 72

Nonetheless this critique of sovereignty, the principle of laissez-faire and the concern with excess of government does not mean that what is advocated is an absence of government. By positing as a standard of government these economic laws of nature in general and the market in particular, the physiocrats lay down the epistemological precondition for a more scientific rule of people and things. The content and form of regulations and interventions that will be needed from the sovereign will now emanate from the object of government itself and will consist of creating and securing the possibilities of liberty and self-regulation. ${ }^{73}$ However, as we will see later, some coercive and illiberal interventions, although regrettable, might be judged from time to time necessary in order to protect natural liberty and create the possibilities for people to act freely.

The second major change taking place with physiocratic thought is the emphasis on the individual. With the new importance accorded to the market as a natural institution revealing the acceptable limit of government intervention, the interplay of individual behaviours as generating order is noticed. This is a significant change of outlook from the

\footnotetext{
${ }^{72}$ Interview of Mercier de la Rivière with the empress of Russian Catherine the Great, cited in Ibid., 198.

${ }^{73}$ Graham Burchell, "Civil society and the 'system of natural liberty'," in Graham Burchell, Colin Gordon and Peter Miller (eds.), Op. Cit., 140.
} 
preceding paradigm. Whereas the cameralist enlightened monarch needed to understand the laws of populations, the physiocratic sovereign needs to secure spaces of liberty for the agency of his or her individual economic subjects. The physiocrats sustain an economic conception of the individual and advance this proto-liberal subject of interest as the primary societal actor of growth and order.

Furthermore, with the principle of laissez-faire arises the ideal and dream of a scientific form of human management. Under medieval economic doctrines, we have to remember, the market was seen as a space to be regulated and ethically directed. The authority needed to make sure a just price was attached to the exchanged goods and that the market was free from theft, fraud, usury and other such impious practices. In other words, medieval economy was imbued with morality and justice. ${ }^{74}$ Theoretically, the idea of the just price referred to a fair and balanced price. ${ }^{75}$ Concretely however, the concept was more loosely applied and referred to the current market price which needed to be enforced by authorities. ${ }^{76}$ Nevertheless the difference in rigidity, the standard of the 'just price' was morally grounded. The origin of this concept is to be found in the Nichomachean Ethics where Aristotle argues that reciprocity in exchange can be found when "things are equalised, so that the shoemaker's product is to the farmer's as the farmer is to the shoemaker."77 Justice in exchange is needed, Aristotle believes, to unite the community as one. ${ }^{78}$ With the physiocratic and later with the liberal conception of the market, the idea of the 'just price' is replaced by that of the 'natural price'. ${ }^{79}$ The importance of that change extends far beyond semantics. The market - now seen as a

\footnotetext{
${ }^{74}$ Michel Foucault, Op.Cit., 32.

${ }_{75}^{75}$ Diana Wood, Medieval Economic Thought (Cambridge: Cambridge University Press, 2002), 135.

${ }^{76}$ Ibid.

${ }^{77}$ Aristotle, Nichomachean Ethics (Indianapolis: Hackett, 1999), 75.

${ }^{78}$ Ibid.

${ }^{79}$ Also called normal price and good price.
} 
natural institution - becomes the standard to judge the correct from the incorrect governmental practices. ${ }^{80}$ In this sense, a good government is not only grounded in moral justice, theological justification, or political conception of the common good, but must now derives its action from the truth of these laws of nature. ${ }^{81}$

\section{Adam Smith and the unintended ordering effect of passions}

Adam Smith and other major figures of the liberal tradition adopted the same belief in a natural and unintended source of order and civilisation. From the perspective of nature and society as a whole, order and harmony is seen as possible even where the bounds of solidarity and friendship were lacking. An invisible hand of nature, passing through individuals' insatiable quest for self-betterment, drives historical development and integrates society. As we will see, however, this does not signify that humans are simply economic beings, driven solely by selfish desires and their motivation for profit. The contradiction between the impersonal order of the Wealth of Nations and the moral bounds portrayed in the Theory of Moral Sentiments is only apparent. The so-called 'Adam Smith problem' is a matter of perspective more than anything else: Smith distinguishes the elevated standpoint of nature and philosophy from the empathic outlook of the moral actor. The invisible hand's orderly force exists at the level of nature and the whole, but it is not a perspective to be adopted by individuals. Influenced by the stoic conception of happiness, Adam Smith still differentiates between mere life and good life, the life of turmoil obsessed with necessity compared with the life of tranquillity and virtue. But if the private life of virtue is still seen as superior to the self-centred view of the merchant, the polity is now subordinated to society, and the political to the economic.

\footnotetext{
${ }^{80}$ Michel Foucault, Op. Cit., 33.

${ }^{81}$ Ibid.
} 
Contrasted with classical-medieval thought, Adam Smith appears as the father of the new economistic order. Contrasted with neo-liberalism, he will come to light as a balanced figure fully aware of the deleterious effects of commercial society.

The Scottish Philosopher was not the only thinker of that period to believe in a spontaneous and natural source of order. Many, in the salons of Enlightenment Europe, enunciate ideas resembling the famous concept of the invisible hand of the market. Dr. Mandeville, for instance, who became infamous for his Fable of the Bees, argued that civilisation's advances and luxuries were primordially the results of private vices and individual appetites. ${ }^{82}$ Influencing Adam Smith's Wealth of Nations, Mandeville first articulates the idea that civilisation's successes are based on the purely self-interested actions of individuals, not public morality. Although, as we will see, the two authors fundamentally disagree on the existence of virtue, the invisible hand metaphor retains the notion of the unintended ordering force of self-interest. By looking for personal advantage, Smith argues, the individual often fulfils indirectly society's welfare:

Every individual is continually exerting himself to find out the most advantageous employment for whatever capital he can command. It is his own advantage, indeed, and not that of society, which he has in view. But the study of his own advantage naturally, or rather necessarily leads him to prefer that employment which is most advantageous to the society. ${ }^{83}$

The same belief is indeed expressed in the Theory of Moral Sentiments: the wealthy's actions, although often moved by rapacious and selfish motives, indirectly benefit the poor, redistribute wealth, "advance the interest of society, and afford means to the multiplication of the species." ${ }^{84}$ The invisible hand brings growth and progress in spite of,

\footnotetext{
${ }^{82}$ Bernard Mandeville, The Fable of the Bees (Oxford: F. B. Kaye, 1924).

${ }^{83}$ Adam Smith, The Wealth of Nations (New York: Bantam Dell, 2003), 569-570.

${ }^{84}$ Adam Smith, The Theory of Moral Sentiments (New York: Prometheus Books, 2000), 265.
} 
not because of, the bourgeois merchant. On its own, the interest of the individual merchant tends towards monopoly and hence runs contrary to the interest of the public. ${ }^{85}$ It is only from the more distanciated viewpoint of society and when balanced by the matrix of the market that this laissez-faire interplay of passions can produce order, civilisation, and the advancement of the specie. It is nature's hand, and not the merchant, which must be applauded for Europe's progress. Tradesmen are judged by Smith as too self-centred to claim a right to leadership. ${ }^{86}$

The liberal solution to self-interest and factions is exposed most clearly from the pen of Madison, an author deeply influenced by Smith, in the foundational Federalist Papers. The force of self-interest and other passions, Madison writes in the tenth paper, must be recognised as part of human nature and as an inescapable dimension of social life. Any form of denial or utopian politics would be doomed to failure. At the same time, liberal thinkers like Madison fear that, if unharnessed, these powerful forces would divide and destroy, through organised factions, the unity of the republic. Rejecting as unwise the destruction of human liberty and as impracticable the homogenisation of society, Madison proposes to play passions against passions and thus assuage their divisive effect:

It is in vain to say that enlightened statesmen will be able to adjust these clashing interests, and render them all subservient to the public good. Enlightened statesmen will not always be at the helm. Nor, in many cases, can such an adjustment be made at all without taking into view indirect and remote considerations, which will rarely prevail over the immediate interest which one party may find in disregarding the rights of another or the good of the whole. The inference to which we are brought is, that the causes of faction cannot be removed, and that relief is only to be sought in the means of controlling its effects. ${ }^{87}$ [Emphasis in original]

\footnotetext{
${ }^{85}$ Adam Smith, The Wealth of Nations (New York: Bantam Dell, 2003), 339.

${ }^{86} \mathrm{Ibid} ., 621$.

${ }^{87}$ Alexander Hamilton, James Madison and John Jay, The Federalist Papers (New York: New American Library, 1961), 80.
} 
Rejecting as futile the classical idea of relying only or primarily on exhortation for the defence of virtue, liberal authors like Madison and Smith transform passions into a movement containing the possibility of their own containment. While a few will be able to follow the inner call of conscience and act as moral actors, societal order as a whole must depend on more solid bases such as habituation, interest, and rules. If, as we will see later, the population must still be warned against the corruption inherent to self-love, it is still preferable to channel individual interests toward the commonwealth than to deny its power.

This principle is not peculiar to the market. The desire for material gain is only the economic dimension of the human pervasive quest for self-betterment. For Smith, the primary mover of society and individuals is passion, a force at the origin of both our natural yet pre-moral desire for gain and our capacity for moral sympathy. Like its name indicates, the underlying logic behind the invisible hand of passions and sentiments is not directly accessible to rational understanding. Like Hegel's cunning of reason, the true end of these interactions, the preservation of life and civilisation, is only revealed in the long run.

If this relation between individualism and order seems quite banal to our modern sensibility, we have to remember that the idea according to which self-interested action can generate social stability was quite heterodox for the time. In Hobbes's philosophy, self-interest is recognised as a primordial motivation in human nature but also as one of the most destructive and problematic forces. At the bottom, it is self-interest which constituted the state of nature were everybody competed against everybody for survival 
and recognition. Self-interest is thus chaos-generating and can only be countered by the all-mighty Leviathan. ${ }^{88}$

In line with the spirit of the emerging science of political economy, Smith is rather sceptical towards well-intentioned pretensions to know the inner functioning of nature and to administer processes like the market. Like the physiocrats, Smith treats as sheer vanity the idea of an enlightened interventionist statesman:

the statesman, who should attempt to direct people in what manner they ought to employ their capitals, would not only load himself with a most unnecessary attention, but assume an authority [...] which would nowhere be so dangerous as in the hands of a man who had folly and presumption enough to fancy himself fit to exercise it. ${ }^{89}$

For Smith, the reason of state differs from that of the market and political prudence demands that the sovereign respects the distinction between human sovereignty and natural law. Equally sceptical is Smith of the possibility of steering people to virtue through moral exhortation. Too utopian on its own, moral exhortation is bound to fail unless it is first based on the more solid grounds of self-interest and justice. The traditional appeal to benevolence and excellence does not understand the need to instrumentalise passion as the prime mover of individuals and society. The importance of moral exhortation however remains. As we will explain in more details later, it remains a necessary practice for the encouragement of high virtues such as benevolence.

Nonetheless, Smith lacks confidence in appealing to high virtues as a sufficient basis for social order and as an appropriate path to virtue for the great majority of individuals. For him, moral philosophy should adopt a pragmatic view of human nature and accept its inherent finitude. Joseph Cropsey, in his important work on Smith, contrasts Smith's

\footnotetext{
${ }^{88}$ M. L. Myers, The Soul of Modern Economic Man: Ideas of Self-Interest, Thomas Hobbes to Adam Smith (Chicago: University of Chicago Press, 1983), 28-33.

${ }^{89}$ Adam Smith, Op. Cit., 573.
} 
virtue by habituation with the traditional path of virtue by exhortation. Unlike the traditional call to virtue of the moralists, Smith's moral philosophy serves as rhetoric, "a mean for working upon men, not to make them 'good' but to make them manageable.",90 In order for earthly virtue to be possible, Smith advocates virtue by habituation, a balancing of the different passions, and an education directing vanity to its proper object. $^{91}$ Again, the unfolding of passions represents for Smith the new immanent ground for moral order; passions hence need to be controlled, not suppressed or sublimated. ${ }^{92}$

The determining role of the passions and, by extension of the economic sphere, is also reflected in Smith's view of progress and world history as expressed in the third chapter of The Wealth of Nations. Dividing human history into four stages, from the age of hunters and gatherers to commercial society, Smith evaluates progress in terms of socio-economic organisation instead of through a classification of political regimes or within a Christian historiography as was the tradition. Unlike other thinkers of the Enlightenment like Hobbes or Locke, Smith approaches progress from the dichotomy rudeness-civilisation and not by contrasting a pre-political state of nature with the coming in existence of civil society. ${ }^{93}$ When Smith highlights human propensity to "truck, barter, and exchange" as unique and defining characteristics of our species, he is not trying to fit human existence into an abstract model like the homo oeconomicus. He is rather trying to locate the origin of the division of labour and highlight this phenomenon as the cause of historical advances and social hierarchies. ${ }^{94}$ For him, economic activity is not superior to

\footnotetext{
${ }^{90}$ Joseph Cropsey, Polity and Economy (The Hague: Martinus Nijhoff, 1957), 26.

${ }^{91}$ Ibid., 23-27.

92 Ibid., 23.

93 Ibid., 58.

${ }^{94}$ Adam Smith, Op. Cit., 2-3. See also the title of Book 1: "Of the causes of Improvement in the productive powers of Labour, and of the Order according to which its Produce is naturally distributed among the different Ranks of the People" in Ibid., 7.
} 
philosophy or politics in absolute terms, yet it is of greater historical importance because it represents a pre-condition for the latters' emergence. The economic is the beginning and the end of society since it encompasses the specialisation leading to private property and classes and creating the possibility of civilisation. Acting as the hand of nature, the economic is the driving force behind history leading to a secular and liberal age "where every man $[\ldots]$ becomes in some measure a merchant and the society itself grows to what is properly a commercial society." 95 Like the Marxist and other structural models of history, Smith's theory of the four stages does not leave a great place to human agency and action. As Brown and McNamara point out, his political economy presents statesmen as shaped by history rather than shaping it. ${ }^{96}$

Moreover, while the Smithian state is a far cry from the neo-liberal night watchman model, his writings nevertheless present the role of this institution as essentially negative, dedicated namely to defence, justice, and the public works necessary for wealth accumulation, commutative justice and the protection of negative freedom. ${ }^{97}$ Smith, it is true, readily acknowledges the limits of the laissez-faire and spontaneous order and supports the fact that there are times when the magistrate's intervention is necessary to defend society. Nonetheless, his liberalism considers the role of the state as primarily negative. Directed at the preservation of life and property, the political sphere is depicted as subservient to the economic and private sphere. Happiness and freedom are to be found in the private sphere, but the state is maintained as an institution necessary to safeguard negative freedom. It is for this reason that Benjamin Constant, in his famous

\footnotetext{
${ }^{95}$ Adam Smith, Op. Cit., 33.

${ }^{96}$ Peter McNamara, Political Economy and Statesmanship, Smith, Hamilton, and the Foundation of the Commercial Republic (Dekalb: Northern Illinois University Press, 1998), 54.

${ }^{97}$ Adam Smith, Op. Cit., 879-916.
} 
speech delivered at the Athénée Royale, warns his compatriots not to forgo entirely their share in the public: "Could we be made happy by diversions, if these diversions were without guarantees? And where should we find guarantees, without political liberty?"98 Since liberals like Constant and Smith are also humanists, it must be added that they also consider political participation as an important part of moral development and personal education. Public participation is second to private happiness but remains an important dimension of individual life, since by "submitting to all citizens, to all citizens without exception the care and assessment of their most sacred interests, enlarges their spirit, ennobles their thoughts, and establishes among them a kind of intellectual equality which form the glory and power of a people." $" 99$ The focus is on the private, but the public sphere is, in their nuanced assessment, regarded as an environment fostering individual autonomy and excellence.

On this ground, many scholars have accused Smith of deflecting political philosophy towards economics and of spearheading liberal capitalism and the rise of economism. In reaction to this reading, a number of more sympathetic scholars have argued that this critique arises from an incomplete assessment of Smith's æuvre and a lack of attention to his moral philosophy. Adopting a more historicist perspective, this second camp tries to re-situate Smith as an $18^{\text {th }}$ century thinker leaving an important place to politics and as someone preoccupied with virtue, education, and freedom. ${ }^{100}$

Studying the Theory of Moral Sentiments, the reader is forced to appreciate Smith as a virtue theorist and to realise that despite his support for commercial society, this author is well aware of the dangers it poses for morality. Social competition for wealth

\footnotetext{
${ }^{98}$ Benjamin Constant, Political Writings (Cambridge: Cambridge University Press, 1988), 326.

${ }^{99}$ Ibid., 327.

${ }^{100}$ Peter McNamara, Op. Cit., 7.
} 
and status is qualified by Smith as both necessary and deceiving. More socially oriented than individualist, the social climber portrayed by Smith ultimately longs for recognition. Through ranks, wealth, and honours, the majority of people seek happiness in the public world, searching for the approbatory look of society. While The Wealth of Nations presents interdependence and the capacity to communicate as the distinctive marks of human society, the Theory of Moral Sentiments adds the desire for recognition as the main object of the drive for self-betterment: "To be observed, to be attended to, to be taken notice of with sympathy, complacency, and approbation, are all the advantages which we can propose to derive from it. It is the vanity, not the ease, or the pleasure, which interests us." ${ }^{101}$ Yet if we all desire happiness, the drive for self-betterment leaves the majority "constantly dissatisfied" because they confuse external contentment with real happiness which requires tranquillity of mind and body. The greatest part of mankind seek to better their condition through social status and economic satisfaction, enthralling themselves in a life of toil and anxiety. ${ }^{102}$ Like Hobbes, Smith distinguishes happiness from felicity: the bustling life of the markets and the courts only leads to ephemeral contentment, not genuine happiness. ${ }^{103}$ Furthermore, this drive towards self-betterment, while natural and made necessary for the advent of civilisation, can become destructive for the very virtues that make this society great:

This disposition to admire, and almost to worship, the rich and the powerful, and to despise, or, at least, to neglect persons of poor and mean condition, though necessary both to establish and to maintain the distinction of ranks and the order of society, is, at the same time, the great and most universal cause of the corruption of our moral sentiments. ${ }^{104}$

\footnotetext{
${ }^{101}$ Adam Smith, The Theory of Moral Sentiments (New York: Prometheus Books, 2000), 71.

102 Ibid., 72.

${ }^{103}$ Charles L. Griswold, Adam Smith and the Virtues of Enlightenment (Cambridge: Cambridge University Press, 1999), 221.

${ }^{104}$ Adam Smith, Op. Cit., 84.
} 
Highlighting fortune as the most "vulgar and obvious way" of self-betterment - the road chosen by the majority - Smith implies the existence of other more socially oriented and stoically infused paths to happiness. ${ }^{105}$ To seek happiness in fortune and glory is a deception of nature, albeit a useful one.

\section{The possibility of virtue}

While Smith recognises some truth in Dr. Mandeville's system and acknowledges the importance of self-interest for societal order and civilisation, he does not consider that self-love should be regarded as a proper standard to guide our choices and actions. From a God-like 'perspective' (sic), the interplay of passions, forces, and interests is always good since it serves the aggrandisement and betterment of the whole of society and of the universe. What is good from the perspective of nature and the whole of society however might not correspond to what is good at the level of the individual. Mandeville might have pointed out an effective force of nature and society, but for Smith he is completely mistaken on its meaning for individuals and morality. His caustic Fable of the Bees has touched upon a very real motivation of human nature but is totally blind to the direction and restraint one must give to such an affect. For this reason, Dr. Mandeville idea only "bordered on the truth." 106 Indeed, Smith does not hesitate to reject Mandeville's system as generally based of sophistry and error. For Smith, the fallacies of the Doctor's tract are numerous, but they all relate to his tendency to characterise all passions as vicious and moved by vanity and his incapacity to differentiate vice from virtue, self-love from selfinterest. ${ }^{107}$ Far from rejecting virtue, Smith's work is trying to propose a new solid ground to reconcile commercial society with the exercise of virtue. Reacting to Tory

\footnotetext{
${ }^{105}$ Adam Smith, The Wealth of Nations (New York: Bantam Dell, 2003), 436.

${ }^{106}$ Adam Smith, The Theory of Moral Sentiments (New York: Prometheus Books, 2000), 459.

107 Ibid., 458.
} 
conservatives lamenting the moral degeneration associated with the growth of the commercial city, Smith's grounding of morality in nature thus opens the possibility of virtue in all aspects of life, including commerce. ${ }^{108}$ Self-love or pure ego cannot be completely evacuated and its role and power has to be acknowledged. In no way, however, is self-love a sufficient basis for society to foster and for individuals to realise themselves. Neither is self-love the sole motivation behind all activities. Pure benevolence might never exist but the majority of our actions are moved by a multiplicity of motivations. Seen in this light, Smith appears neither as a disciple of Dr. Mandeville and the doctrine of self-love, nor as a nostalgic believer of the aristocratic civic virtues like Lord Bolingbroke, but as mediator, a pragmatic virtue theorist wishing to infuse and temper the worldly passions of commercial society with a diluted form of stoicism. In terms of the relation between the political and the economic, Smith appears as an ambiguous figure, elevating private virtue above the public life and ascribing the economy as the primary factor of civilisation while still praising the great men of action and the need for martial spirit.

Smith first criticises Mandeville for rejecting virtue as a fraud and as the "mere offspring of flattery begotten upon pride." ${ }^{109}$ In his opinion, Mandeville is wrong to reduce our longing for recognition and approbation to mere vanity. Smith's whole moral philosophy is predicated on sympathy and on the fact that our moral sensibility is based on the outlook of others and of our own conscience. Virtue lies precisely in the sensibility of the actor to judge the property of actions and motivations, to know what should be done, what should be longed for, and what should be avoided. But property of moral

\footnotetext{
${ }^{108}$ Leonidas Montes, "Notes on Das Adam Smith Problem," Journal of Economic Thought 25, No. 1 (2003): 145.

${ }^{109}$ Adam Smith, Op. Cit., 452.
} 
conduct cannot be learned in isolation, this kind of moral knowledge can only be developed through socialisation and the conscience of others' judgement. For one to search what is honourable and worthy of esteem or even for one to seek glory for deeds worthy of it should not be confused with vanity: "This frivolous passion [vanity] is altogether different from either the two formers, and is the passion of the lowest and least of mankind, as they are of the noblest and the greatest." ${ }^{110}$ Desiring worldly recognition does not necessarily entail vanity; in some cases it can even encourage moral conscience and an higher standard of virtue.

The "licentious system" offered by Mandeville has the deleterious effect of lowering all people to the same level of amorality and self-centeredness. For Smith this generalisation is not only factually false but also pedagogically dangerous. Throughout the Theory of Moral Sentiment, Smith distinguishes hierarchical ranks of virtues and people. Smith does not deny that the "great mobs of mankind" are primarily motivated by low virtues such as prudence and self-interest. But besides this ordinary social standard, Smith projects the higher moral standard of the stoic actor. Smith's moral philosophy thus traces two unequal ways to happiness and self-betterment. On one side, the great masses of commercial society and the men of small politics live by the lower virtue of prudence, whether private or public. In the higher echelon of that first group of people, lies a small minority of "great men of actions" who truly dedicate their life to something higher. Still higher in the rank of virtues are the stoic sages, whom he also refers to as the "wise and virtuous men." The lives of these virtuous sages approach most closely the absolute property of action and the complete self-command demanded by the standard of the impartial spectator. Smith tries to offer a high moral standard that is nevertheless

${ }^{110}$ Ibid., 453. 
compatible with passions and commercial society. Presenting the impartial spectator as a continuum of virtue, he wishes to show that the city is not hostile to the practice of private virtue. In his system of moral sentiments, the great majority will practice the low social virtues while a minority of self-conscious actors will reflect a milder version of stoic apathiea.

To illustrate the different paths to virtue, Smith first presents us the model of the prudent, patient, and fair working man, the archetype of ordinary virtue. This brave man belongs to a great commercial city like London: he is, for Smith, the living example that this environment can foster moral character. While the prudent man exercises lower forms of virtue than the wise and virtuous sage, he is not reducible to an economic man who would be lead by his bodily appetites and by utility. A lesser reflection of the impartial spectator, the lower and private virtues are still born of the same human capacity for sympathy that makes possible the high and public directed virtues. When making a prudent judgement on self-interest, sacrificing present enjoyment for security and future growth for instance, the prudent man shows a certain degree of detachment and selfcommand. In fact, one of Smith's objectives is to convince us that self-interest does not necessarily entail vice and that it can even, when tempered by a sense of prudence, be a virtuous motivation. ${ }^{111}$ Once mediated through prudence (the low virtue representing the detached judgement of the impartial spectator on self-interest), self-interest can indeed cultivate other qualities worthy of general approbation such as "the habits of oeconomy, industry, discretion, attention, and application of thought." ${ }^{112}$ Above all else, the prudent man is portrayed as a sober and reserved individual. He is, it is true, primarily driven by

\footnotetext{
${ }^{111}$ Ibid., 452.

${ }^{112}$ Ibid., 445.
} 
self-interest. Still, his behaviour is at the antipodes of that of a man consumed by selflove, vanity, and present satisfaction. Keeping himself at bay of society's intrigues and cabals, the prudent man is always sincere but does not always tell the whole truth. ${ }^{113} \mathrm{He}$ is of course capable of friendship but prefers steady relationships based on good conduct rather than passionate transports of camaraderie. His simple character completely foreign to the manners and the spirit of the salons and convivial societies: "Their way of life might too often interfere with the regularity of his temperance, might interrupt the steadiness of his industry, or break in upon the strictness of his frugality." "114 We can see from his portrait of the prudent man that Smith's model of ordinary life and virtue opposes, rather than encourages, the modern model of the economic maximising and profit-focused man. In control of his desires, Adam Smith's prudent man is an economic man who has become social, a simple and honest character exemplifying the Calvinist work ethic. Resisting the pessimistic assessment of Tory conservatives, the Scottish thinker tries to reconcile economy and morality, the commercial city and virtue, by illustrating the possibility of a low form of virtue available to everybody and easily amenable to the interest-driven and temptation-laden nature of the commercial city.

But if the ideal of the prudent man is suitable for the great majority, there exists a much higher path to virtue and happiness. The private and prudent man only brings cold esteem, not love or admiration from the impartial spectator. ${ }^{115}$ Much more admirable, the "wise and virtuous individual" will show a balance of the four cardinal virtues (prudence, justice, benevolence, and self-command) and a willingness to sacrifice his self-interest to

\footnotetext{
113 Ibid., 312.

${ }^{114}$ Ibid., 313.

${ }^{115}$ Ibid., 316.
} 
the interest of his social order or civil society in general. ${ }^{116}$ Contrary to the great masses of the earth who are confusing ranks and fortune with happiness and utility with property $^{117}$, the few wise and virtuous individuals accept steadily their fate as part of the greater good and at the end as the work of a benevolent deity:

So Smith's system teaches us that it is permissible for a 'great Conductor' to 'poison the happiness' of individuals, to 'afflict and mortify the individual', to disregard 'the conservation and prosperity... of any private individual', to inspire in us a 'respectful affection' for brutal tyrants and esteem for the noble military exploits of even 'very worthless characters', and to 'sacrifice [individuals'] little systems to the prosperity of a greater system' - all in the putative interest of society, of 'the whole'. 118

Whether in public or private life, for Smith everyone should ultimately aim at this ideal of virtue. If one desires genuine happiness and tranquility of life, this person should accept his fate as a soldier marching enthusiastically to glorious death. Such a stoic attitude does not need to be associated with a rejection of this world, for it is only in the process of sympathy, a reflexive conscience of others' existence, that one can come to this elevated moral standpoint. Smith's mild apatheia is embracing, not rejecting, the world; he applies to the social order this detached attitude that ancient stoicism reserved for nature. Standing between ancients and moderns, Smith wishes to keep some of both worlds. In his second-best city, worldly virtue is possible, but it lies neither in sheer individualism nor in pure dispassionate abandonment of one-self. As Athol Fitzgabbon rightly notes, the social occupies a central position in Smith's moral theory: "In summary, Smith modified Ciceronian virtue by introducing society

\footnotetext{
${ }^{116}$ Ibid., 346.

${ }^{117}$ Smith calls this confusion of means and ends the 'Spirit of System'. People take enjoyment in the systems they develop such as economies or government apparati and forget that those were supposed to serve another purpose. Likewise, we get attached to utility as an end in itself; the perfection of the system has the same effect on us than aesthetic attraction. Adam Smith, The Wealth of Nations (New York: Bantam Dell, 2003), 257-268.

${ }^{118}$ Andy Denis, "Was Adam Smith an Individualist?," History of the Human Sciences 12, No. 3 (August 1999): 83.
} 
as an intermediate term between the individual and God. Society first taught the individual to moderate his self-love and to cultivate dispassion and selfcommand."119 The social life of urban setting offers for Smith a space where consciences meet each other. The public gaze of the social acts as a moral standard and encourages the exercise of virtue.

But have these social virtues anything to do with the political? Should we interpret Smith's virtuous men as private individuals or public heroes? Here again the ambiguous relationship of Smith to the political realm becomes evident. The virtuous "reformer[s] and legislator[s]", those truly devoted to the common good, are elevated by Smith as the "greatest and noblest of all characters." 120 Their love of country and dedication is for Smith truly admirable and demonstrates great virtue. However admirable these great men of actions are, their first virtue is still prudence, a virtue of lower rank than self-command and benevolence. These great political actors, even if superior to the majority, evaluate their conduct on the basis of custom and ordinary morality. Comparing themselves to that second rate standard they become conscious of their superiority and subject to vanity. Much more demanding of themselves, the wise and virtuous individuals try to imitate the property of action and the perfection of the impartial spectator, this demi-god within. ${ }^{121}$ Although this goal is ultimately unattainable, since he can never equal in perfection the “divine artists" archetype", his sensibility to this higher standard, his mastery of the cardinal virtues and his self-consciousness raise him above others. The wise man is originally moved by the same nature than the person of ordinary virtue: the desire to be

\footnotetext{
${ }^{119}$ Athol Fitzgibbons, Adam Smith's System of Liberty, Wealth, and Virtue (Oxford: Clarendon Press, 1995), 68

${ }^{120}$ Adam Smith, Op. Cit., 316, 341.

${ }^{121}$ Ibid., 363-364.
} 
happy, a need for approbation, and a reliance on the same impartial spectator for moral judgement. The degree to which he approaches the detachment of the impartial spectator and his higher exercise of self-command and benevolence are what raises him above the many. As an artist, he has worked upon himself to shape his conduct closer and closer to the "great judge and arbiter of conduct", impartial conscience. ${ }^{122}$ The prudent and patient man of industry, of ordinary virtue, fabricates a world around him; the wise and virtuous man is first concerned with working upon himself. Both are homo faber seeking happiness but only the second is conscious of the end of utility and creation: tranquillity and social harmony.

This idea is in every man more or less accurately drawn, its colouring is more or less just, its outline are more or less designed, according to the delicacy and acuteness of that sensibility with which those observations were made, and according to the care and attention employed in making them. In the wise and virtuous man they have been made with the most acute and delicate sensibility, and the utmost care and attention have been employed in making them. Every day some feature is improved-every day some blemish is corrected. He has studied this idea more than other people; he comprehends it more distinctly; he has formed a much more correct image of it, and is much more deeply enamoured of its exquisite and divine beauty: he endeavours as well as he can to assimilate his own character to this archetype of perfection. ${ }^{123}$

Because of the human need for recognition and the happiness one finds in sympathy, very few despise ranks, distinctions or prominence. The wise and virtuous person who can reject such honours as unimportant and rely only on property to conduct his or her life is "so confirmed in wisdom and philosophy" that he or she is "raised very much above [...] the ordinary standard of human nature." 124 Moreover, like Cicero taught in the story of the dream of Scipio, the fame and glory one can gain in this world is ephemeral and

\footnotetext{
122 Ibid., 363.

${ }^{123}$ Ibid., 363-364.

${ }^{124}$ Ibid., 81 .
} 
contingent on fortune. ${ }^{125}$ The honour of the wise and virtuous, in contrast, is based on the absolute property of their conduct and is therefore eternal. ${ }^{126}$

Moreover, the praised figure of the "great man of action" is not representative of Smith's view of the political sphere in general. These are individuals of exception, founders and reformers. Ordinary court politics on the contrary is decried as a theatre of appearance, etiquette, vanity, for which Smith has much less respect. The portrait Smith gives of princes, courtiers, and other "men of rank and distinction" is not a flattering one. The great admiration conferred upon their persons by the mass is due less to virtue than to the title they bear and the majesty emanating from court etiquette. Even Louis XIV, the most powerful prince in Europe for most of his reign, acquired his reputation not from heroism, knowledge, a sense of justice, or other such talents, but from a certain grace in his voice, deportment and attitude which suited perfectly his office and his rank in the eyes of the beholders. ${ }^{127}$ Institutions may ultimately rest upon the hard work and genuine talents of civil servants, but great authority is often the result of a combination of power and a capacity to perform well one's social role so as to transpire distinction and superiority. ${ }^{128}$ Such are the function of the arts of ordinary court politics. People of inferior stations are obliged to show great talent and ambition to stand above their peers, gain admiration, and climb to high governmental offices. ${ }^{129}$ They even turn to war, Smith remarks, as an opportunity to distinguish themselves and show valour. Those born in high stations, in contrast, shy away from all difficulty, labour, and real danger: "to figure at a

\footnotetext{
${ }^{125}$ Marcus Tullius Cicero, On the Commonwealth, trans. George Holland Sabine and Stanley Barney Smith (Indianapolis: The Bobbs-Merrill Company, 1929), 256-268.

${ }_{126}$ Adam Smith, Op. Cit., 370

${ }^{127}$ Ibid., 75-76.

${ }^{128}$ Ibid., 78.

${ }^{129}$ Ibid., 77.
} 
ball is his great triumph, and to succeed in an intrigue of gallantry, is highest exploit." 130 Smith respects the ambition and hard work of public servant but despises court politics as the art of flattery and appearance. Smith portrayal of court politics as undignified and contemptible can also be read as a response to Tory conservatism: not only is virtue possible in the commercial city, Smith argues, but the lower virtues associated with the economic realm and private prudence (patience, industry, fortitude, and application of thought) are often superior to the decadence of the court. In fact, Smith even counsels anyone wishing to remain "free, fearless and independent" to stay away from the "circles of ambition" and not to compare one-self to "those masters of the earth who have already engrossed the half mankind." 131 In the exceptional cases of the "great men of action", this path to political power could lead to high virtue and civic accomplishment but for the majority of people of ambition it would breed vain glory and lead to a broken life. ${ }^{132}$

The widespread interpretation of Smith as a completely economistic thinker is largely due to a misreading of his view on benevolence. Smith doubts universal benevolence but does not universalise self-love as the primary human motivation or rejects benevolence altogether. Too many of his readers have thrown out the baby with the bathwater in this regard. Holding the virtues of Enlightenment against fanaticism, Smith's moral theory proposes a foundation for moral interactions moulded for this imperfect world. Like Hobbes, Smith is wary of religion. He sees its call for perfection as unfitted as a practical and deontological source of morality: "In defending the standpoint of ordinary life, Smith rejects moral theory that imposes demands we cannot meet and

\footnotetext{
${ }^{130}$ Ibid., 78 .

${ }^{131}$ Ibid., 80.

${ }^{132}$ Ibid.
} 
that requires guilt we ought not to bear." 133 Sceptical of the philosophers' search for perfect systems, Smith defends a vision of the Enlightenment where the scope of wisdom is limited to the knowledge of the limits of the cave. ${ }^{134}$

Far from supporting a vision of the economic as an independent and a selfsufficient realm, Smith thus construes a model of society where economic and natural liberty is protected but in which justice ensures fair play and in where high virtues like benevolence and self-command are constantly encouraged.

Smith's recognition of the importance of self-interest does not make him an absolute critic of the state. Contrary to contemporary neo-classical economists, Smith does not hold a libertarian position. This is particularly evident on the subjects of education and defence. For instance, Smith justifies the state imposed basic military education. This obligation to take part in the defence of the land is even prioritised over the right to do commerce or join a corporation. ${ }^{135}$ With Smith, and arguably in opposition to contemporary neo-liberalism, the economy is still at the service of society and not the other way around. A realist, Smith considered wealth as dependant on non-economic factors such as security, moral and national exigencies. His studies focus on the subject of wealth, yet he does not deny the existence of separate spheres of existence nor projects he wealth as the primary moral standard. The economic historian Karl Polanyi contrasts Smith with the latter market ideologues by stating that for the former economy remains one part among others of the life of the community. ${ }^{136}$ In his perspective, the limits of state interventions are important to highlight but the existence of markets and the free

\footnotetext{
${ }^{133}$ Charles L. Griswold, Op. Cit., 142.

${ }^{134}$ Adam Smith, Op. Cit., 309.

${ }^{135}$ Adam Smith, The Wealth of Nations (New York: Bantam Dell, 2003), 887-888.

${ }^{136}$ Karl Polanyi, The Great Transformation, The Political and Economic Origins of Our Time (Boston: Beacon Press, 2001), 116.
} 
pursuit of self-interest is ultimately conditional on the existence of a community and a state. Smith's balanced opinion on government confirms the compatibility of selfinterested motivations with the existence of a pluralistic realm of social and moral order. According to Smith, self-interest represents an important but not totalising principle of government; economic-based rationality is a major human motivation but it cannot exist without justice nor can it supplant the exercise of virtue.

\section{Harmony and the civic eye}

We would thus be mistaken to interpret the Smithian liberal subject as simply an atomised and self-seeking individual. In this respect, the liberal governmental program differs significantly from the neo-liberal totalisation of the market and homo oeconomicus models. Classical liberal thought differentiates the state from the cultural/social spheres it construes as natural (the market, religion, civil society, the nation, etc.) and seeks a balance between governing and recognizing that these domains function under different rationalities. ${ }^{137}$ Unlike neo-liberalism, classical liberalism is completely opposed to the universalisation or systematic replication of the market as a rationality and technique of government. As in economic thought the individual is conceived as part of a population, in the realm of moral and political thought the economic subject is equally counted as a moral subject, a member of civil society. This is because liberal government develops both from the growth of individualism and the birth of the social (or civil society as it was more commonly called in early liberal writings). Liberal government can thus be said to be multidimensional; the subject is approached as being a member of and dwelling in

\footnotetext{
${ }^{137}$ Graham Burchell, "Liberal government and techniques of the self," in Andrew Barry and others (eds.), Foucault and Political Reason: Liberalism, Neo-liberalism and Rationalities of Government (Chicago: University of Chicago Press, 1996), 24.
} 
different spheres of activity and existence, be they religious, cultural, economic, political, and so forth.

Albeit all their dissensions, liberal thinkers from Hobbes to Smith were trying to ground political order on new foundations. Witnessing the Scientific Revolution of Copernicus and Newton, they were all confronted with a major existential crisis. Such thinkers realised that order had to rest on a different basis than the traditional transcendent symbolism of Christianity. ${ }^{138}$ Sheldon Wolin recounts: "The need to establish a field of intelligible meanings among political phenomena becomes acute when traditional and political arrangements appear to be breaking down into a kind of primal condition." 139 In such a period of instability, these thinkers looked for a principle of social harmony which would provide order as Newton's Law awarded harmony to the universe. In the case of Smith this principle was our capacity and tendency to socialise, a principle of human behaviour inscribed in the nature of the individual and society themselves and independent of external authority. ${ }^{140}$

The majority of liberal thinkers did not rely mainly on self-maximising actions to ground social order. As Dean explains, they tried instead to harmonise the new subject of freedom and interest of liberalism with the moral subject of civil society. ${ }^{141}$ Although liberal thinkers credited self-maximising actions as order-generating, most of them looked at social conscience and empathy as better sources of social integration. As Wolin reminds us, early liberalism was all but advocating an egotistical or autonomy-seeking conscience:

\footnotetext{
${ }^{138}$ Sheldon S. Wolin, Politics and Vision, Continuity and Innovation in Western Political Thought (Boston: Little, Brown and Company, 1960), 218.

139 lbid., 244.

${ }^{140}$ Ibid., 292.

${ }^{141}$ Mitchell Dean, "Sociology after Society," in David Owen (ed.), Sociology after Postmodernism (London: Sage, 1997), 210.
} 
Liberalism has always been accused of seeking to dissolve the solidarities of social ties and relationships and replace them by the unfettered, independent individual, the masterless man. In reality, the charge is almost without foundation and completely misses the liberal addiction for social conformity. ${ }^{142}$

The liberal imperative for social conformity is explicit in the writings of Locke who affirm the 'laws of opinion' to be more effective than official laws and in those of Rousseau who call for the harmonisation of one's private conscience with the general will of the public. ${ }^{143}$

In this spirit, the third Earl of Shaftesbury, a student of Locke and a member of the English parliament, turns to natural morality as the source of order. Unlike classical philosophy and Christianity, Shaftesbury does not ground moral behaviour in a transcendent reason or in revealed truth. The Reformation and the Scientific Revolution have indeed shaken people's confidence in their capacity to attain this kind of pure knowledge of natural essences or of God's will. It is in this context that Shaftesbury conceives of an innate moral sense which enables us to distinguish right from wrong. ${ }^{144} \mathrm{~A}$ lover of nature, Shaftesbury sees in this sense the principle of order necessary for us to base our everyday moral actions. ${ }^{145}$ Shaftesbury does not deny the existence of selfinterest but emphasises communal bounds and teaches to fuse one's own interest with the public good. Again, this philosophy denotes a longing for a new ground for order and social harmony. As a body shows symmetry, Shaftesbury argues, self-love needs to be balanced with the love of fellowship. ${ }^{146}$

Another thinker of the Scottish Enlightenment advanced further the idea of a sensus communis. Siding with Shaftesbury against Hobbes and Mandeville, Hutcheson

\footnotetext{
${ }^{142}$ Sheldon S. Wolin, Op. Cit., 343.

${ }^{143}$ Ibid., 343-370

${ }^{144}$ Milton L. Myers, Op. Cit, 51.

${ }^{145}$ Ibid., 53.

${ }^{146}$ Ibid., 54.
} 
denounces self-interest as too narrow and inadequate to answer all ethical questions. As Myers explains, Hutcheson conceived of the moral sense as prior to interest calculation: "two people, he argues, may serve my interest equally well, but my reactions towards the one who served from his self-interest and toward the other one who served from friendship, with no thought of gain, would differ greatly." ${ }^{147}$ As we have a sense of aesthetic beauty, we can equally discern the morally commendable from the reprehensible, a moral sense he qualify as benevolence. ${ }^{148}$ Both self-love and benevolence are regarded by Hutcheson as sources of social cohesion. Even though Hutcheson values the moral sense as superior to self-interest, he makes clear that order cannot be sustained without one or the other. ${ }^{149}$

In the same sense, both Shaftsbury and Hutcheson critique Mandeville for being blind to the moral sense they believe humans have naturally in order to distinguish virtue from vice. In their perspective, limiting human motivation to immediate self-interest eclipses all actions motivated by a striving for the common good or by a natural moral intuition. For Hutcheson, this moral sense is the only disposition that can explain our affection for distant heroes and our tendency to differentiate between advantageous objects and advantageous fellows. We cannot always decipher a "secret chain" relating our love for others' virtue and self-advantage. Such love for virtue and excellence arises not from cold calculating reason, but from this moral sense that is superior to the balance of interests. ${ }^{150}$ In essence, both agree that human beings are striving for happiness but decry Mandeville for occulting our moral longing for excellence:

\footnotetext{
${ }^{147}$ Ibid., 68

${ }^{148}$ Ibid., 69

${ }^{149}$ Ibid., 69

${ }^{150}$ Francis Hutcheson, An Inquiry into the Original of our Ideas of Beauty and Virtue, Volume 1

(Hildesheim: Georg Olms Verlagsbuchhandlung, 1971), 118-119.
} 
For in this we should all agree, that happiness was to be pursued, and in fact was always sought after; but whether found in following Nature, and giving way to common affection, or in suppressing it, and turning every passion towards private advantage, a narrow self-end, or the preservation of mere life, this would be the matter in debate between us. ${ }^{151}$

In a similar fashion, Adam Smith sought the loci of balance and harmony in laws of nature. As we saw earlier, self-interest was approached by Smith as a natural source of order. Behind the apparently self-serving and chaotic individual actions was a natural law at work that tended towards achieving equilibrium of public welfare. However, unlike modern economists, Smith did not restrain himself to one discipline and sought such a natural law of order in different spheres of human activity. In his Theory of Moral Sentiments Smith looks into the a priori conditions which makes morality a possible source of social concord. ${ }^{152}$ Smith calls sympathy the principle of human communication and relationship making morality possible. ${ }^{153}$ According to this definition, sympathy denotes one's participation in the sentiments of others not a simple approbation of them. ${ }^{154}$ Hence sympathy does not refer to the content of morality but to humans' natural and instinctive capacity to adopt another perspective when judging moral conducts. ${ }^{155}$ Living in a condition of human plurality, we identify imaginatively with others' position and even feel some of their happiness or misery. ${ }^{156}$ From the possibility of the moral spectator to identify with others arises his or her capacity to judge their

\footnotetext{
${ }^{151}$ Shaftesbury, "Sensus Communis" from Characteristics (1711), ed. John M. Robertson. (Indianapolis: Bobbs-Merill, 1964), 80-81.

${ }^{152}$ Adam Smith, The Theory of Moral Sentiments (New York: Prometheus Books, 2000), 23.

${ }^{153}$ Glenn R. Morrow, The Ethical and Economic Theories of Adam Smith (New York: Augustus M. Kelley Publishers, 1969), 29.

${ }^{154}$ Ibid., 27

${ }^{155}$ Just like Rousseau's image of the 'happy savage', Smith's moral spectator could not exist before the advent of civil society. Although Smith was certainly influenced by his teacher Hutcheson, his concept of sympathy emphasises the sociability of the moral subject instead of positing an individual and pre-given instinct. See Ibid., 33 .

${ }^{156} \mathrm{Ibid} ., 30$.
} 
action according to the felt concurrence or dissonance between the two positions. In essence, the moral spectator develops a moral judgement by assessing weather his or her sentiment would accord with that of the actor. In the same way, self-judgements are possible because we can imaginatively take an external and distanced position to judge as if we were looking at ourselves from the judging eye of the public or of another spectator. $^{157}$

The theory of sentiments does not mean, however, that moral judgements can simply be derived from egotistical or fanciful opinions we might have on others or that others might have on us, for this would lead to a moral relativism that Smith does not endorse. The problem is how to reconcile passion with morality, and interest with moral objectivity. When confronted with a difficult moral decision involving high personal stakes, however, the individual's decision cannot be made solely on mood or opinion. The problem at this stage is twofold. The first difficulty is of methodological nature. The spectators will not be fully capable of empathising with a situation in which he or she has no interest. The second problem relates to the resoluteness of our moral decision when passions fly high. Reflexive judgement based on sympathy might not always be stable and strong enough to counter self-love. In case of grave danger for our security or when the lives of our friends are at risk, it becomes difficult to take the necessary moral distance.

Smith suggests two solutions to answer these challenges and to harmonise selfinterest and empathy. To the methodological problem, Smith proposes the concept of the impartial spectator. When a moral judgement involves high personal stakes, when imagination is not able to excite the involved passion (e.g. hunger), or when the passions

${ }^{157}$ Ibid., 31 . 
arose by the spectacle are too strong and distort judgement, the spectator cannot be expected to share the interest of the actor and cannot fully judge 'objectively'. ${ }^{158}$ In all of these cases where the moral spectator cannot evaluate on its own merit the propriety of another's action, he should adopt the detached perspective of an imaginary third person: the impartial spectator. As Lindgren explains, this third party represents the ideal mean of interest that should prevail in a community for its maintenance: "the equitable degree of interest in such objects is the one which is expected to provide and sustain the basis of as concord of sentiments among men. This level of interest defines the image of the ideal disposition, i.e., the impartial spectator." 159 The impartial spectator is hence supposed to provide us with the distance necessary for moral judgements.

If the impartial spectator solves the problem of methodology, there remains the question of individual resoluteness with regards to moral principles. When judging their own actions and personal well-being is involved, Smith believes most people will not be able to face death or danger and choose ethically on their own. Smith believes this is the reason for the edification of universal and permanent moral codes. Continual moral observations on the concurring sentiments of mankind have led us to lay down general rules, which we can refer to when in need. ${ }^{160}$ Thus the individual is not left alone and can appeal to a universal conscience to guide his or her actions.

As with the market and the economic order in general, ethical judgements and actions are thus connected through the natural moral fabric of civil society. The correspondence does not end there. In the same way that Smith is sceptical of the capacity of the sovereign to understand and regiment economic laws; he doubts our capacity to

\footnotetext{
${ }^{158}$ Ralph J. Lindgren, The Social Philosophy of Adam Smith (The Hague: Martinus Nijhoff, 1973), 29-30.

${ }^{159}$ Ibid., 28.

${ }^{160}$ Glenn R. Morrow, Op. Cit., 34.
} 
understand rationally this moral order. ${ }^{161}$ To conclude on this question, we can see that the moral order defended in the Theory of Moral Sentiments does not contradict the selfinterested individual of the Wealth of Nations. On the contrary, moral sentiments and selfinterests are regarded by Smith as two parallel sources of social order, the former superior and more rewarding and the later assuring the possibility of a well-ordered polity even when virtue is lacking. Smith believes the sympathetic process mirrors in society the law of nature and represents a way to reconcile in the modern city self-interest and virtue. ${ }^{162}$ Like all mirrors however, the image is reversed. From the standpoint of nature or God, the order and good of the whole is what is proximally considered. From the human standpoint, what comes proximally is the particular, and we are first benevolent to those who are close to us: our families, our neighbours. The poet Alexander Pope, whom Smith personally admired, illustrates with great imagery this complex relationship. Because it captures so vividly Smith thought, it is worth quoting at length:

Self-love thus push'd to social, to divine, Gives thee to make thy blessing thine. Is this too little for the boundless heart? Extend it, let thy enemies have part: Grasp the whole words of Reason, Life, and Sense, In one close system of Benevolence: Happier as kinder, in whate'er degree, And height of Bliss but height of Charity. God loves from Whole to Parts: but human soul Must rise from Individual to the Whole. Self-love but serves the virtuous mind to wake, As the small pebble stirs the peaceful lake; The centre mov'd, a circle straits suceeds, Another still, and still another spreads, Friend, parent, neibhour, first it will embrace, His country next, and next all human race, Wide and more wide, th'o'erflowings of the mind Take ev'ry creature in, of ev'ry kind;

${ }^{161}$ Ibid., 42.

${ }^{162}$ Athol Fitzgibbons, Op. Cit., 57. 
Earth smiles around, with boundless bounty blest, And Heav'n beholds its image in his breast. ${ }^{163}$

Ultimately, there is no opposition between self-love and benevolence; the wise, with the help of the impartial spectator process, can come to adopt a stoic vision of the world closer to that of Nature and God. Limited by human finite perspective however, we need self-interest to socialise, reach others, and finally learn to be benevolent to an increasingly larger circle.

The compatibility of self-interest and concerned or benevolent sympathy is highlighted in the very first words of the Theory of Moral Sentiments: "How selfish soever man may be supposed, there are evidently some principles in his nature, which interest him in the fortune of others, and render their happiness necessary to him, except of seeing it." ${ }^{\prime 64}$ Portraying Smith as a full-blown advocate of self-interest is a common yet erroneous reading. Like Hutcheson, Smith considers self-interest as necessary in the economic sphere as this famous passage renders explicit: "It is not from the benevolence of the butcher, the brewer, or the baker, that we expect our dinner, but from their regard to their own interest." ${ }^{165}$ Nonetheless, it is our capacity to be 'other-directed' and not selfinterest that differentiates us as human beings. ${ }^{166}$ Self-betterment can be attained from either self-interest or moral virtue, but the second avenue is superior insofar as it projects a higher form of self-control. Of course, one could argue with some basis that sympathy is only an indirect application of self-interest. What is clear is that Smith's theory is marked by the need to recognise the power of self-love and the pervasiveness of the private perspective in moral or public judgements. Far from an unconditional appraisal of

\footnotetext{
${ }_{163}^{163}$ Alexander Pope and Maynard Mack, An Essay on Man (London: Methuen and Co. Ltd., 1950), 162-164.

164 Adam Smith, Op. Cit., 3.

165 Adam Smith, The Wealth of Nations (New York: Bantam Dell, 2003), 23-24.

${ }^{166}$ Samuel Fleischacker, On Adam Smith's wealth of Nations (Princeton: Princeton University Press, 2004), 88.
} 
self-interest, however, what follows is the construction of economic and moral systems aimed at the channelling of self-interest towards a humanist or civic good.

Adam Smith's economic and moral theory thus comes out as part of a philosophy of moderation, looking for an immanent source of order and proposing a form of human excellence suited for the imperfect beings that we are. To be fair, a large part of his scepticism towards the public realm is a reaction the pettiness and self-serving court politics of his times and not a rejection of the political as such. To his pragmatic eyes, the philosophers perennial temptation to create political systems grounded in transcendence does not take into account human beings inherent limits and finitude. ${ }^{167}$ As Charles Griswold clarifies, Smith rejects all ideas of a perfect political order or even a perfect community of stoic sages and settles for a secondbest system: "to see this is to understand the limit of the rule of mere passion and force, as well as of the rule of perfect virtue and philosophy." ${ }^{168}$ Smith readily acknowledges that the order he proposes is not perfect: the fusion of sympathies between the actor and the spectator can never be complete. Anti-utopian, Smith nevertheless judges the realised harmony sufficient for societal integration: "These two sentiments, however, may, it is evident, have such a correspondence with one another, as is sufficient for the harmony of society. Though they will never be unisons, they may be concords, and this is all that is wanted or required." 169 Carved for imperfection, this social arrangement between interests and sentiments permits some harmony between the individual and society and encourages the cultivation of private virtues.

\footnotetext{
${ }^{167}$ Charles L. Griswold, Op. Cit., 304.

${ }^{168}$ Ibid., 309.

${ }^{169}$ Adam Smith, Op. Cit., 23.
} 
III

In the preceding chapter, we defended the thesis that classical liberalism, when judged in comparison to earlier theories of government and economics, represented an expansion of the role and importance of the economic sphere. However, as we also stressed, classic liberals such as Adam Smith were discreet in their appraisal of commercial society and did not generalise the reality of the market place to society as a whole. Early liberals conceived of the economic as only one realm amongst others and regarded the market as only one reflection of a natural force bringing harmony and order to the whole. Even if Smith advocated laissez-faire in most economic exchanges, he did not sacralise this precept or frame all questions in the model of the market. In fact, he welcomed state intervention in several instances and maintained a rich conception of the civil society. Like numerous classical liberals, Smith accepted the existence of a multiplicity of social spheres. Reacting against a history of complete devaluation of things economic, he and others tried to give this realm respectability and legitimacy and highlighted its role in society. In no way however, did they conceived of the market as the centre of society or place the economic at the core of human nature.

In the present chapter, we will study how neo-liberalism, a movement reclaiming the heritage of classical liberalism, departs from that prudent outlook to advance a radically economistic position. In the first place, we will consider how neo-liberalism adopts the theory of spontaneous order as an axiom for its entire intellectual edifice. As the most philosophical and elegant synthesiser of that theory, most neo-liberals turned to Friedrich Hayek and the Austrian School of Economics to rethink economics as a science of order and to define the market as a matrix of self- 
generating order. Nevertheless, Hayek's theory was overall less influential than the Chicago School of Economics. Moreover, the influence of Kant and Polanyi on Hayek's theory makes it naturally hostile to the generalisation of the economic model and rationality we see taking place with the Chicago stream of neo-liberalism, which does not mean that Hayek's thought is not economistic in nature. In fact, there is no doubt that Hayek champions the economic as the realm of liberty and rejects the political as the realm of coercion. However, while he does not seem fully aware of it, Hayek's anti-rationalism cannot condone the totalisation of the economic supported by the Chicago School. For these different reasons, our study of neo-liberalism focuses on the Chicago School of Economics and its derivatives as the ideal representative of radical economism. After briefly recounting neo-liberalism's historical and intellectual origins, we will turn to the Chicago School of Economics and to its infants Public Choice Theory and Rational Choice Theory as radically economistic theories representing a rationalistic turn. Mainly, we will make the case that American neo-liberalism (i) expands the economic in an totalising fashion by expanding the market and homo oeconomicus paradigms across the board, (ii) by conceiving of individuals as entrepreneurs of themselves, (iii) by enlarging the field occupied by economic science, (iv) and by re-writing history and culture through the lens of the market model. Because they have attained the status of economic orthodoxy and have been able to influence all aspects of society, neo-liberal ideas are not only important from the perspective of intellectual history but first and foremost because of what they represent and what they do: they radically expand the economic at the expense of other modes of Being-in-the-world and in particular of political existence. Although our analysis of American neo-liberalism draws considerably 
from the Chicago School of Economics, the phenomenon we wish to highlight is larger than this particular academic school. The phenomenon under study, radical economism, comes under different denominations and presents itself under the emblem of different schools including but not limited to the Chicago School, Rational Choice Theory, Social Choice Theory, Public Choice Theory, New Public Management, New Economic History, and so forth. Distinctions and disagreements clearly exist which separate these schools and warrant their distinct denominations. However, in the matter that concerns us - the position of these schools with regards to the position of the economic in relation to the political - they share a common vision.

In order to better understand the neo-liberal revival of the idea of spontaneous order on which is legitimated the expansion of the economic sphere, one has first to replace the emergence of neo-liberal thought back in its historical context, that of Keynesian orthodoxy. As Susan George recounts, in the post-war period, Keynesian and socialist interventionism was the norm:

In 1945 or 1950, if you had seriously proposed any of the ideas and policies in today's standard neo-liberal toolkit, you would have been laughed off the stage or sent off to the insane asylum. At least in the Western countries, at that time, everyone was a Keynesian, a social democrat or a social-Christian democrat or some shade of Marxist. The idea that the market should be allowed to make major social and political decisions; the idea that the State should voluntarily reduce its role in the economy, or that corporations should be given total freedom, that trade unions should be curbed and citizens given much less rather than more social protection-such ideas were utterly foreign to the spirit of the time. ${ }^{170}$

\footnotetext{
${ }^{170}$ Susan George, "A Short History of Neoliberalism," Conference on Economic Sovereignty in a Globalising World (March 1999), in Global Policy Forum, http://www.globalpolicy.org/globaliz/econ/histneol.htm (accessed May 19 $9^{\text {th }}, 2006$ ).
} 
Brought about by the Great Depression, the predominance of the Keynesian doctrine in academia and government was concretised by the arrival in the White House of two publicly declared Keynesian presidents: Kennedy and Johnson. During the 1950's and 1960's the Chicago and Austrian schools were in a position of minority, standing amongst the last bastions of laissez-faire economics. This isolation brought the two universities closer: Chicagoans were welcome in Vienna as allies and vice versa. Hayek himself spent twelve years teaching at the University of Chicago, working closely with figures such as Knight and Friedman and influencing their understanding of the market order. This position of academic marginality endured until important economic dislocations and population discontent (OPEC crisis, stagflation, opposition to taxes and burden of social programs, etc.) in the 1970 s opened the door for a paradigmatic shift. ${ }^{171}$

During his years of tenure at Chicago, Hayek formulates and disseminated his theory of the unintended order. Associating state interventionism with Nazi Germany and Bolshevik Russia, Hayek develops with his teacher von Mises a radical anti-socialist attitude unbeknownst in most economists of the earlier Austrian School. For Hayek, there can be only two choices: liberalism or statism. The second choice, whether it takes the form of so-called "democratic centralism" or social-democracy, leads for him inexorably to totalitarianism:

There exists no third principle for the organization of the economics process which can be rationally chosen to achieve any desirable ends, in addition to either a functioning market in which nobody can conclusively determine how well-off particular groups or individual will be, or a central direction where a group organized for power determines it. Once it is clearly recognized that socialism as much as fascism or communism inevitably leads into the totalitarian state and the destruction of the democratic order, it is clearly legitimate to provide against our inadvertently sliding into a socialist system by constitutional

\footnotetext{
${ }^{171}$ Elton Rayack, Not so Free to Choose: The Political Economy of Milton Friedman and Ronald Reagan (New York: Praeger, 1987), 4.
} 
provisions which deprive government of the discriminating power of coercion even for what at the moment may generally be regarded as good purposes. ${ }^{172}$

This economist-philosopher brings to its limit the liberal association of political liberty with economic freedom. In his very dichotomous vision, no political liberty is possible without complete economic laissez-faire and socialist calls for social justice or positive rights are part of a fatal deceit which can lead a free people to servitude. Calling himself "an Old Whig, with the stress on the old," "173 Hayek affiliates himself with a tradition he calls 'individualism true', in the company of thinkers such as Locke, Mandeville, Hume, Smith and Burke. ${ }^{174}$ Above all, individualism true rejects rationalist and constructivist pretensions of possessing perfect reason and designing society in accordance to an ideal plan. ${ }^{175}$ The tradition of individualism true Hayek associates himself with is contrasted with the individualism false of Descartes, Rousseau, and the encyclopaedists who dangerously flatter human pride by exalting the power of reason and by praising freedom as unbounded will. Rejecting all ideas of societal order being handed down from above or contracted out from below, Hayek proposes a more organic vision of civilisation's development, picturing this process not as a rational formation but as a series of institutions formed through evolutionary selection over millennia. The Austrian economist is not so optimistic about the reach of human reason and deliberative action. In the end, for Hayek, there is no Society but only societies, private circles of collaboration from which emanates an immanent order surpassing the intent and foresight of the

\footnotetext{
${ }^{172}$ Friedrich A. Hayek, Law, Legislation and Liberty, Volume 3: The Political Order of a Free People (Chicago: The University of Chicago Press, 1979), 151.

${ }^{173}$ Gilles Dostaler, "Friedrich Hayek sa vie et son cuvre," in Gilles Dostaler and Diane Ethier (eds.), Friedrich Hayek, philosophie, économie et politique (Montreal: ACFAS, 1988), 44.

${ }^{174}$ Friedrich A. von Hayek, "Individualism: True and False," in Chiaki Nishiyama and Kurt R. Leube, The Essence of Hayek (Stanford: Hoover Institution Press, 1984), 144.

${ }^{175}$ Ibid., 136.
} 
actors. ${ }^{176}$ His distrust for constructivism and the coercive power of the state leads him to adopt radically economistic views. In his famous essay Individualism True and False, Hayek juxtaposes and contrasts the market as a free institution and the state as an instrument of coercion. Hayek links freedom with individuals instead of collective entities but rejects as a mere caricature of individualism the idea that society is composed of atomised individuals. ${ }^{177}$ Rather, Hayek highlights, individualism true focuses on media of collaborations such as cultures, traditions, and the market. Such collaborations integrate individuals and foster a self-sustaining order which is greater than the simple zero-sum equation of the individuals' deeds. ${ }^{178}$

Rejecting anarchism as yet another mask of the rationalist constructivism he decries, Hayek recognises the impossibility to forego entirely state coercion. On that question, Hayek agrees with Hobbes: without the state monopoly of coercive force, civilisation is impossible; life is "solitary, poor, nasty, brutish and short." 179 Yet for him state order is only a precondition to the emergence of civilisation and in no way does it represent the backbone sustaining society together and holding people to commit injustice. On that question, Hayek parts way with the Hobbesian approach. To Hayek, Hobbes is delusional about human capacity to create a rational dominion from the ground-up and about his desire to order society as one index lexicon. Far more promising for him is the possibility of self-control encouraged by social community and religion ${ }^{180}$ as well as the market's potential to benefit the community without having to rely on either

\footnotetext{
${ }^{176}$ Ibid., 135.

${ }^{177}$ Ibid.

$178 \mathrm{Ibid}$.

${ }^{179}$ Hobbes, Op. Cit., 76.

${ }^{180}$ Warren S. Gramm, "From Individualism True to Individualism False," in Warren J. Samuels (ed.), The Chicago School of Political Economy (East Lansing: Michigan State University, 1976), 169.
} 
benevolence or explicit state demand. ${ }^{181}$ The definition of this pre-rational order can help us decipher the rationale behind Hayek's radical anti-political stance which will taint his students and the members of the Chicago School. Like many others, Hayek returns to Ancient Greece to lay down the concepts at the basis of his political and economic thought. Besides the natural order (physis) - completely independent and indifferent of human action - and the rationally designed order (taxis) lies another form of order, spontaneous and sub-rational. ${ }^{182}$ Hayek conceives of this third form of order as a human artefact resulting from a long process of evolution accumulating over history the practical knowledge from human interactions. ${ }^{183}$ Understood as one of the most fundamental of a number of spontaneous orders, the force resulting from integrated free markets (cattallaxy) takes a much larger role than the traditional definition of economic as the domain of production and exchange. The word cattallaxy is coined by Hayek from the Greek word kattalasein to characterise the market order as a pacifying and integrating force. The economic can now compete with the political as the supreme realm of human interactions since cattallactics order not only means a network of exchange but the possibility to "admit into the community and to change from enemy into friend." 184 One can see that the political is here no longer deemed necessary, only some governmental force is required. Political logos is effectively replaced by economic exchange as the integrating nexus; the marketplace is substituted for the public forum and the agora as the

\footnotetext{
${ }^{181}$ Friedrich A. Hayek, Op. Cit., 138.

182 Such ideas are not completely original. One can see a continuous trend in the history of western thought opposing Being as Designed Formation and Being as Emanation.

${ }_{183}$ John Gray, Hayek on Liberty (Oxford: Basil Blackwell, 1984), 28.

${ }^{184}$ Friedrich A. von Hayek (exerts from), "Spontaneous ('Grown') Order and Organized ('Made') Order, in Naomie Moldofsky (ed.), ORDER-With or Without Design? (London: The Centre for Research into

Communist Economies, 1989), 116.
} 
unifying space making possible plurality in unity, and superficially dissonant offers and demands replace the void of agonistic dissonant public voices.

Hayek's conception of the unintended order, on which is based his valorisation of the market, is also contrasted with the state, politics and all forms of command in a most rigid dichotomy. ${ }^{185}$ Belonging to the category of imposed order, politics is rejected as a dangerous human chimera. The state and politics in general, associated with coercion and exclusive power, are thus opposed to preferred self-ordered systems like the market. Waligorski's study of the political theory of conservative economists highlights the point of agreement of Hayek with the Chicago School on the market/politics dichotomy: "[to Friedman and Hayek] Coercion does not exist in the market. Only government can coerce people, making government the major threat to freedom. [...] The market is, therefore, the absolute essential arena for the exercise of freedom." ${ }^{186}$ Following this association of the state with unfreedom, Hayek argues the need to restrict the power of the state whenever possible and to limit politics to a negative and juridical apparatus. According to his constitutional theory, one must reject laws seeking to govern, command and instruct, and support instead the few substantive laws which only seek to regulate "the relations between the private persons or between such persons and the state." ${ }^{187}$ Hayek again borrows from the Greeks, this time from the foundational concept of isonomia, to critique total democracy. In his judgement, to follow the rule of law is not to legislate on everything but to be bound by meta-legal principles insuring liberty. ${ }^{188}$ In this

\footnotetext{
${ }^{185}$ In fact, the opposition he draws between liberalism and statism is derived from his ontological and epistemological ideas concerning the importance of the unintended order for civilisation.

${ }^{186}$ Conrad P. Waligorski, The Political Theory of Conservative Economists (Lawrence: The University Press of Kansas, 1990), 54-55.

${ }^{187}$ Friedrich A. Hayek, The Constitution of Liberty (Chicago: The University of Chicago Press, 1972), 207.

${ }^{188}$ Hayek's distinction between these two forms of law shows great insight on the modern phenomenon

Foucault calls the "governmentalisation of the state", i.e. the fact that laws are increasingly not interdictions
} 
perspective, the role of the state is almost completely negative, its purpose is only to make possible and secure spheres of responsibility from which the individuals can interact.

When one understands that by 'coercion' Hayek means any positive, significant, or purposeful action engaged by institutions above the individual level, one understands that his theory is not only libertarian but anti-political:

The three great negatives of Peace, Freedom and Justice are in fact the sole indispensable foundations of civilisation which government must provide. [...] Coercion can assist free men in the pursuit of their ends only by the enforcement of a framework of universal rules which do not direct them to particular ends, but, by enabling them to create for themselves a domain protected against unpredictable disturbance caused by other men - including agents of government - to pursue their own ends. ${ }^{189}$

Hayek's ideal role of the state is thus profoundly apolitical and negative. The state represents this pre-civilised force that must trace and protect the boundaries of the private spheres. The public is reduced to a buffer zone for the private, a negative space which exist so that people can distinguish "between thine and mine." 190 The role of politics is reduced in favour of the market and other unintended orders, and what remains is directed at creating the possibility of an economistic existence.

Yet Hayek comes from the continental philosophical tradition and that heritage makes him stand out in Chicago. Hayek's philosophical beliefs, in particular his Kantian critical attitude towards the power of human reason and his Polanyian appraisal of

\footnotetext{
but positive instructions, commands, creations of subjects: "the great majority of so-called laws are rather instructions issued by the state to its servants concerning the manner in which they are to direct the apparatus of government and the means which are at their disposal.", see Ibid., 207. His analysis is, in our opinion, flawed however since it only understands this phenomenon in statist and legalist terms whereas it parallels the rise of bio-politics, the economisation of rule, and the retreat of sovereignty.

${ }^{89}$ Friedrich A. von Hayek, Law, Legislation and Liberty, Volume 3, The Political Order of a Free People (Chicago: The University of Chicago Press, 1979), 131.

${ }^{190}$ Friedrich A. von Hayek, "Individualism: True and False," in Chiaki Nishiyama and Kurt R. Leube, $O p$. Cit., 142.
} 
practical knowledge, gives a level of complexity and deepness to his economic argument that is not to be found in his American followers. The philosophical character of Hayek's thought has an equivocal effect. In the first place, the epistemological foundation of Hayek's thought makes his vision of society very economistic by opposing a conception of politics associated with statism, rationalism and constructivism with a conception of things economic and the market which are associated with the unintended order, civilisation and freedom. In the second place however, Hayek's epistemology also creates an internal limit to his own economism. Because his economic ideas are rooted in a rejection of rationalism and constructivism, he cannot support, without internal contradiction, any totalisation of the economic sphere. Hayek can praise without inconsistencies the market as an epistemological device gathering a fragmented and dispersed form of practical knowledge. Still, we argue that his philosophy cannot condone without contradiction the tendency of the Chicago School to force all institutions into the model of the enterprise and to apply market rationality to the entirety of the social domain. One can find explicit statements supporting this analysis. For instance, Hayek explicitly rejects the "extension of economic man as the proto-typical base of human behaviour in general." ${ }^{191}$ Understanding the danger of economic totalisation, Hayek also associates this totalising tendency that will in time become the norm at the Chicago School as a form of individualism false: "this strategic element in the decision process decision theory - has been extended from allocation of economic resources to provide the conceptual basis for an "economics of welfare, manners, language, industry, music and

\footnotetext{
${ }^{191}$ Friedrich A. Hayek, Law, Legislation and Liberty, Volume 3: The Political Order of a Free People (Chicago: The University of Chicago Press, 1979), 135.
} 
art [and] war...power [and] love." 192 Against the generalisation of economic choice rationality to all forms of behaviour and against total economism which in the end is a form of rationalism, Hayek's neo-liberalism retains the socially constrained individualism of classical liberalism. In a less uni-dimensional account of the Social, the market is not pictured as the only force at play in societal order, religion and self-restraint are key for a free form of order. ${ }^{193}$ Also, Hayek does not really care if the state intervenes economically, as long as it does not affect the integrity of the private sphere (i.e. as long as it is not significant). To do so would probably end up a bad decision, but it is not to be decried as a violation of freedom. Moreover, as far as Hayek's ideas can act as a powerful critique of statist socialism, it cannot justify the predominance of the market (catallaxy) as a unintended order over other unintended orders such as traditions, citizen political activity, anti-rationalist streams of socialism and other activities escaping design. Its depiction of politics as the unfortunately inevitable locus of coercion does not account for the activity of politics or for what the political life entails but only for what has come to be known as government. It is no wonder that Hayek can see no truth in discourses of positive rights, for his account of the public sphere only contains rules and commands, a structure of fair play and a coercive force that, while necessary for the private to grow in peace, must be restricted and always distrusted.

\section{The rationalistic turn and economic imperialism}

From Hayek to the Chicago School, there is displacement as well as continuity. Influential figures of the Chicago School of Economics adopted Hayek's radical anti-

\footnotetext{
${ }^{192}$ Warren S. Gramm, "From Individualism True to Individualism False," in Warren J. Samuels (ed.), The Chicago School of Political Economy (East Lansing: Michigan State University, 1976), 175.

${ }^{193}$ Friedrich A. von Hayek, "Individualism: True and False," in Chiaki Nishiyama and Kurt R. Leube, Op. Cit., 135-139.
} 
political attitude and made theirs his idea of the market as an unintended and spontaneous order. Compared to post-war Vienna, it is much easier to understand and to account for the libertarian roots at the basis of Chicagoans' anti-political attitude. Less subtle and complex however, the Chicago School's form of neo-liberalism is no longer the result of a systematic philosophical reflection and lacks the internal limit Hayek's Kantianism imposed on its own economism. The American stream of neo-liberalism can be, without much exaggeration, qualified as total economism. No longer adopting a defensive stance, it seeks without restraint to expand the reach of economic and market rationality to all institutions and actors. The public is not only warned of the danger associated with politics, it is educated as to the ubiquitous virtues of the market and as to the absolute necessity for the state and the citizen to frame their behaviour in that mindset.

Indeed, the move from the Hayekian world view to Chicago School ideology represents a rationalistic turn. The main reason Chicago School's proponents can apply the logic of the market and of the consumer to all fields of reality and in particular to politics lies in their emphasis on choice, decision-making calculus and, most of all, utility or profit maximisation. The Chicagoans ignored Hayek's anti-rationalism but retained his idea of the market as a structure of social order. Whereas Hayek rejected the extension of short-term interest as the "proto-typical base of human behavior in general"194, the Chicago School bases its approach on such a generalisation. Friedman for instance equates the economic with the model of the market and considers that all parts of life can be analysed as constrained maximisation. ${ }^{195}$ Others are even blunter in their enlargement of the economic field. Summarising advances of economic theory, George J. Stigler,

\footnotetext{
${ }^{194}$ Ibid., 172-174

${ }^{195}$ Warren J. Samuels, "The Chicago School of Political Economy: A Constructive Critique," in Ibid., 9-11.
} 
another major figure of the Chicago School and winner of the Nobel Prize, divides the development into two general trajectories. The first trajectory of advance comprises, without surprise, all research furthering the empirical knowledge and the understanding of economic exchanges. But our knowledge of 'normal economics' is only one-side of the economists' mission. As the second trajectory of advance, Stigler points to what many have called economic imperialism, and what he refers to as the "the widening of the working range of the microeconomist to encompass phenomena previously treated as exogeneous in economics." ${ }^{196}$ Economic science is seen as the new master science that will at last unite the social sciences as one coherent whole.

This overt opening to academic imperialism brings some neo-liberals to lower the monument dedicated to Smith. They remain respectful of this figure of authority but reject his pluralism as a pre-modern artefact, an aberration contradicted by the rest of his thought. Most if not all in the Chicago School claim Smith as a founding figure of economics and a prophet of the free market. At the same time however, many are uneasy with the enduring distinction between politics and economics that transpires in his writings. For a radical economist like Stigler, the main limitation to Smith's ideas is their lack of consistency. Was he more coherent, he would have understood that the motivation of utility-maximisation he discerned in the marketplace is also the logic at play in all human behaviour, politics included. In essence, for Stigler one does not have to refute Smith, only to be more Smithian than Smith himself:

The "uniform, constant, and uninterrupted effort of every man to better his condition" (I, 304 [326])-why was it interrupted when a man entered Parliament? The man whose spacious vision could see the Spanish War of 1739 as a bounty and who attributed the decline of feudalism to changes in

\footnotetext{
${ }^{196}$ George J. Stigler, Chicago Studies in Political Economy (Chicago: The University of Chicago Press, 1988), ix.
} 
consumption patterns-how could he have failed to see the self-interest written upon the faces of politicians and constituencies? The man who denied the state the capacity to conduct almost any business save the postal - how could he give the sovereign the task of extirpating cowardice in the citizenry? How so, Professor Smith? ? $^{197}$

By transposing the economy as a science primarily concerned with order, radical economistic movements like the Chicago School of Economics come to deny the utility of political science and, in the end, of the necessity of a political sphere altogether. This marks a departure with the traditional conception of politics but also of the economy. The primary concern of the economy becomes the rationalisation and ordering of human behaviour on market logic and not the simple production and exchange of goods and services. After all, their theory provides concepts and institutions ready to take the place of those pertaining to the political world: it offers a model of inter-personal relationships - the market - and a model of socio-political harmony - general equilibrium. Although economists can show some interest in the behaviour of the individuals who lie behind the supply and demand curve, it is the focus on equilibrium itself that distinguishes economics from other social sciences. ${ }^{198}$ More than an epistemic tool, the curve of supply and demand acts as a the underlying principle of a self-generating order, a kind of perfect state of nature, never actualised but perpetually sought after. This ultimately artificial point of rest serves as a technocratic matrix of order. Neo-classical economy, through the instrument of market equilibrium, provides a general model of order from which it is possible to reconfigure all relationships. This order, while explicitly rejecting transcendence, is based on an abstraction of exchange, stripping human relationships

\footnotetext{
${ }^{197}$ George J. Stigler, The Economist as Preacher, and Other Essays (Chicago: The University of Chicago Press, 1982), 144.

${ }^{198}$ Edward P. Lazear, "Economic Imperialism," The Quarterly Journals of Economics 115, No. 1 (February 2000): 101 .
} 
outside time and society. A limited relationship is severed from its reality and entered into a functional order, under the condition that everything remains equal (ceteris paribus). This methodological proviso, when combined with market-oriented decisionism, has tremendous implications. The belief that 'everything remaining equal, the market will unfold' implies amongst other things the general status quo, the autonomy of market relationships, the generalisation of economic rationality and the need to discipline those who do not abide by this circumscribed reality. Unlike with Adam Smith moreover, no extraneous force is needed to civilise or temper the citizens. "Equilibrium suggests a magnetic force that draws events towards a coherent pattern and determines the form of economic change and movement through time." ${ }^{199}$ As Keynes noted, neo-classical economics seeks nothing less than a Copernican system where "all the elements of the universe are kept in their places by mutual counterpoise and interaction." ${ }^{200}$ Unlike most political conceptions of order, the neo-liberal's spontaneous order does not presuppose or require acts of founding, reforms, revolutions, or any other disrupting interventions in the world. Re-framed in the model of the market, political activity contains processes and utility function, but no action properly called. Robert A. Solo's critique of neo-classical assumptions sheds light on the conception of time and change they imply: "There is movement in the neoclassical system, but no development. The neoclassical system moves perpetually; it never comes to rest. And it does not develop."201 In the last chapter, we will explore in more depth, with Arendt as our primary guide, the inadequacy of the economic conception of change to explain political existence.

\footnotetext{
${ }^{199}$ Robert A. Solo, "Neoclassical Economics in Perspective," in Warren J. Samuels (ed.), The Chicago School of Political Economy (East Lansing: Association for Evolutionary Economics and Graduate School of Business Administration, 1976), 49.

${ }^{200}$ John M. Keynes, Essays in Biography (London: Macmillan, 1933), 223, cited in Ibid.

${ }^{201}$ Ibid.
} 
Aggressive and adaptive in their encounter with other disciplines, radical economists support the colonisation of other fields of existence, justifying it with a belief in monism and with the hope of a unifying social science. With the Chicago School of Economics and the constellation of schools defending an economistic vision of politics, market-based rationality - utility maximisation and cost/benefit calculation - is generalised as human behaviour. The concept of 'good' being expanded to include all things bearing some utility or profit, the economy as the realm of the production and exchange of goods and ideas is ipso facto enlarged to encapsulate all human activity. While the object of utility or profit sought by the individual might not be categorised as economic, this is a mere detail since, fundamentally, the structure of the behaviour is. Brennan and Buchanan are clear: the essentially economic character of things lies in their structure and not their particular end or function:

There are several ways of viewing political processes in the same terms as we view markets. The first, and most important at this point, is the view of political process as a system of interacting individuals from which outcome emerge as equilibria. This view is consistent with any number of motives we might ascribe to those individuals and with any number of criteria by which we might evaluate the operative rules. The motives and criteria in question can be chosen from the economist's toolkit. [...] What is crucial here however, is neither actor motive nor evaluative criteria but, rather, a preparedness to examine political process in the same general term as we examine market. $^{202}$

The economic is therefore defined as a form of self-ordered rationality where individuals, constrained by rules and the choices of others, make decisions in a maximising logic. Through this definition, the economic is at the same time reduced and enlarged. The economic is reduced to a specifically market oriented and utility maximising logic. At the

\footnotetext{
${ }^{202}$ Geoffrey Brennan and James M. Buchanan, The Reason of Rules, Constitutional Political Economy (Cambridge: Cambridge University Press, 1985), 15.
} 
same time however, defining the economic as a form of decision making rationality renders possible its application to all fields and spheres of existence:

Another word that has been attributed to radical economism is economic imperialism. We already noted in this chapter that economic emperialism - the application of economic models and theories to other fields and sciences - is an enterprise that is regarded by economistic thinkers as an important avenue of the expansion of the economic field. ${ }^{203}$ Interestingly, some economists explicitly laud economic imperialism as a brilliant scientific uncovering of the core of all social life. To them the individual and the firm are no different than the atom in physics and chemistry, that is, ubiquitous. ${ }^{204}$ In its appraisal of economic imperialism, Edward Lazear traces two different routes on which the expansion of the economic field has advanced. The first path, points Lazear to praise the inclusiveness of economist, encourages scholars outside the discipline to adopt economic analysis to understand social phenomena. ${ }^{205}$ The second possibility, judged by Lazear equally successful, is to colonise the other disciplines and take the chairs of noneconomic scholars. ${ }^{206}$ This author is very candid and honest in exposing the second strategy: "simply replace outsiders as analysts of 'noneconomic' issues, forcing noneconomists out of business, as it were, or at least providing them with competition on an issue in which they formerly possessed a monopoly." ${ }^{207}$ Lazear's economism is also

\footnotetext{
${ }^{203}$ The term economic imperialism is more precise than radical economism. This precision represents both the virtue and the limit of this term. Economic imperialism is best used to describe the application of economic model and rationality to other academic disciplines. While an important dimension of the phenomenon of economism, we do not believe the later can be reduced to this form of intellectual imperialism. The phenomenon of economism is not restricted to the University but also shows its effects in our everyday consciousness, in our actions or lack thereof, in the mode of interaction and subjectivity encouraged (consumer-citizen).

${ }^{204}$ Edward P. Lazear, "Economic Imperialism," The Quarterly Journal of Economics, (February 2000): 105 .

${ }^{205}$ Ibid., 104.

${ }^{206} \mathrm{Ibid}$.

${ }^{207}$ Ibid.
} 
totalising, there is virtually no limit to the expansion of the economic field. The most aggressive economic imperialist, Lazear states candidly that economic imperialism "aim[s] to explain all social behaviour by using the tools of economics." 208 In this perspective, neo-liberals refuse as a rule to distinguish the rationality of the homo oeconomicus from the forms of subjectivity deployed in politics, arts, religions, and so forth. Arguably, the Chicago School of Economics understands all parts of life as amenable to economistic analysis of advantage and utility. ${ }^{209}$ As demonstrated by the following citation, the uni-dimensionality of the economistic outlook reaches, at times, surrealistic proportions: "The law of demand is readily applicable to sex, honesty, dates, highway speeding, babies, and life itself! We predict that if the price of any one of these things goes up, the quantity demanded will diminish and vice-versa." ${ }^{10}$ Again, we need to remember that the relevance of such statements lies not solely in their veracity or falsity. Beyond the truth it reveals and the reality it obscures, such a discourse also represents a theorising act affecting our existential and phenomenological reality, transforming our conception of social reality, widening the sphere of the economic and vitiating it of the political.

Following that spirit of economic imperialism, neo-liberal thinkers like Buchanan consider that economic rationality must be used in political analysis and preferred over the model of the 'benevolent despot' or other alternative paradigms. While incapable of proving that economic rationality is the primary or central form of human reason ${ }^{211}$,

\footnotetext{
${ }^{208}$ Ibid., 103.

${ }^{209}$ Warren J. Samuels, "The Chicago School of Political Economy: A Constructive Critique," in Warren J. Samuels (ed.), Op. Cit., 11.

${ }^{210}$ Lawrence H. Officer and Leanna Stiefel, "The New World of Economics: A Reviewed Article," in Ibid., 464.

${ }^{211}$ It seems to us that such a proof would be impossible to provide. To prove that economic rationality is the only or even the primary form of rationality, one would have to resort to a form of circular logic and to
} 
Buchanan places the burden of proof on economism's detractors: "The initial burden of proof must surely rest with anyone who proposes to introduce differing behavioural assumptions in different institutional settings. [...] for the economist, the only difference in institutions that are relevant for explaining behavioural differences are the differences in the price of the alternatives." 212 On which ground does Buchanan base such an ontological and epistemological generalisation? Not on truth, nor liberty, nor justice, but methodological facility. ${ }^{213}$

The Chicago School is perhaps the most articulated and transparent exponent of neo-liberal radical economism, but it is by no means the only manifestation of that movement. Precisely because it colonises and remoulds every terrain it encounters, radical economism has many faces. One of its most concrete and explicit reflections is the development and the growth in popularity of economic approaches to the study of politics such as the school of public choice, rational choice theory, as well as the so-called new public management. These approaches to politics, which are nothing other than the application of economic models to its study, are derived directly from Chicago School microeconomics. They represent, in sum, a very important facet of radical economism: the aggressive and totalising expansion, across academic disciplines and fields of activity, of economic rationality. More topical to our study, they represent the colonisation by the economic field of the discourse and science dedicated to the study of political activity and

provide the demonstration with the aid of economic rationality or to contradict himself/herself. Any monist world view is to be conceived as an abstraction or else must be based on a leap of faith. But this question, which brings us back to the perennial philosophical debates which rages since Parmenides and Heraclitus, extends far beyond the scope of this thesis.

${ }^{212}$ Geoffrey Brennan and James M. Buchanan, Op. Cit., 48-49.

${ }^{213}$ Ibid., 51. 
thought. ${ }^{214}$ In his introductory guide to the field of public choice, David B. Johnson could not more clear in his desire to see the economic field enlarged. For this author, the reduction of the economic to what has been traditionally understood as economics is mistaken. The following passage is so bold and explicit that it warrants a exhaustive citation:

Contrary to the layman's belief that economics is reserved to a study of the stock market, inflation, or the production and consumption of material goods to satisfy material wants, economics is much more general. There is an economics of love, an economics of time, an economics of crime and punishment, as well as an economics of material goods; most importantly, these are not separable "economics". Each of these "economics" is based upon a foundation of a common set of analytical tools. Economics is not defined by the subject area it studies, since its domain has become the limitless field of human choice. ${ }^{215}$

In order to fit political reality into an economic model, economistic theories like public choice theory translate the normal language of politics into the language usually associated with economic exchanges. The objective of such translation is not to make it more 'operational' or more scientific as one could guess from empiricists. While it would be useless to try to decipher their inner intentions or motives, the language utilised by public choice theorists effectively masks all difference between the nature of the political and the economic. The reader, encouraged to see citizens as consumers and to evaluate policies in terms of offer and demand is no longer troubled by the totalisation of the economic sphere.

Following this approach, voters can be likened to consumers; political parties become entrepreneurs who offer competing packages of services and taxes in

\footnotetext{
${ }^{214}$ The matter is not only academic. With the study of politics mimicking the study of economics and the language used in this understanding translated to see politics in terms of exchanges, prices and goods, something is lost. The question is neither a simple matter of linguistic. Arguably, with this translation is lost a certain access to consciousness of things political and with it, a part of political existence itself becomes inaccessible.

215 David B. Johnson, Public Choice, An Introduction to the New Political Economy (Mountain View: Bristlecones Books, 1991), 17.
} 
exchange for votes; political propaganda equates with commercial advertising; government agencies are public firms dependant upon receiving or drumming up adequate political support to cover their costs; and interest groups are cooperative associations of consumers or producers of public goods. Moreover the whole political system can be viewed as a gigantic market for the demand and supply of 'public goods', meaning all output supplied through a political instead of a market process $[\ldots]^{216}$

The same is true of rational choice theory, another very popular instance of neo-liberal radical economism. Rational choice theory, just like the Chicago School of Economics, extends economics' methodological individualism, replicates its market-based conception of individual behaviour and rationality and seeks to apply economic logic to political questions. The incredible success of rational choice theory in academic journals and its maverick penetration in political science departments reflects in itself the advance of economism. ${ }^{217}$ In their famous critique of rational choice theory, Green and Shapiro list the four "generally accepted assumptions" of rational choice theory as follows: (i) rational behaviour is characterised as utility maximisation, (ii) rational action requires consistency in ordering options (options can be rank-ordered and preference orderings are transitive), (iii) the value the individual seeks to optimise is 'expected' (because choice must often be made in uncertain conditions), and (iv) the relevant analytical unit is the individual. ${ }^{218}$ Although Shapiro and Green are foremost critics of rational choice theory, their account of this framework's definition of rationality is not denied by the 'believers'. George Tsebelis for instance, in an application of the rational choice model to comparative

\footnotetext{
${ }^{216}$ Peter Self, Government by the Market? The Politics of Public Choice (Boulder: Westview Press, 1993), 3.

${ }^{217}$ Originating in the $1950 \mathrm{~s}$, the application of rational choice theory to political science has gained its predominant position throughout the last three decades. As an example, the number of articles based on this theory that were published in the American Political Science Review has almost doubled between 1982 and 1992. See Donald P. Green and lan Shapiro, Pathologies of Rational Choice Theory, A Critique of Applications in Political Science (New Haven: Yale University Press, 1994), 3. 218 Ibid.
} 
politics, presents rationality as "nothing more than an optimal correspondence between ends and means." ${ }^{219}$ He later defines rationality further by adding these requirements on rational behaviour: it is expected-utility maximising, the beliefs or preferences cannot be contradictory, preferences cannot be intransitive, and reason conforms to the axioms of probability calculus. ${ }^{220}$ After presenting these conditions of rationality as the 'weak' requirements, he further borrows from the economic model by basing his 'strong' requirements on the theory of equilibrium strategy and situating the locus of rational choice analysis on the institutional constraints imposed on rational actors. ${ }^{221}$ Recognising the parental position of neo-classical economics towards rational choice theory, Tsebelis cites Milton Friedman, who stands, as we already saw, as one of the main figures of the Chicago School of Economics, to defend the epistemological value of the methodological framework. ${ }^{222}$ Evelyne Huber and Michelle Dion, in their assessment of the contribution of Rational Choice Theory to the study of Latin American politics, also list similar assumptions to define the rational choice paradigm: utility maximisation, structured preferences (transitive and rank-ordered), and a focus on individual or unitary actors' strategic choices to explain collective outcomes. ${ }^{223}$ She also points out to the kinship of neo-liberal economics and Rational Choice Theory: "in the most restricted sense, the rational choice approach is the political application of microeconomic theoretical assumptions to the study of politics, or the use of economic models for the study of non-

\footnotetext{
${ }^{219}$ George Tsebelis, Nested Games, Rational Choice in Comparative Politics (Berkeley: University of California Press, 1990), 18

${ }^{220}$ Ibid., 24-27

221 Ibid., 40

222 Ibid., 31

${ }^{223}$ Evelyne Huber and Michelle Dion, "Revolution or contribution? Rational choice approaches in the study of Latin American politics," Latin American Politics and Society 44, No.3 (Fall 2002): 2
} 
market phenomena."224 Regardless the fact that some rational choice theorists wish to incorporate cultural elements in the theory they also remain fateful to utility maximisation and to cost and benefit calculating rationality. ${ }^{225}$

Furthermore, neo-liberal radical economism, in all its forms, also entails an active and continuous reconfiguration of the world along market lines. More constructivists than conservatives, closer to Bentham than to Burke, American neo-liberals do not oppose intervention per se, only anti-liberal interventions, i.e. interventions that do not serve to encourage the spread or enforcement of markets arrangements. At times, neo-liberal schools have even been actively engaged in state reforming. Public choice, which is in reality a subset of rational choice theory, has played a strategic role in supporting privatisations and the application of market rationality in government's decision-making. Rational choice theory has been promoted as the prime perspective in policy making, its popularity in part driven by a movement to push politics out of government:

[...] Rational models are seen not merely as some bundle of techniques to do policy analysis. The mission of public/rational choice practitioners has become, in our view, far more ambitious; the objective for many devotees of rational models is to supplant the pushing, bargaining, and noise of democratic politics with the putative elegance and parsimony of a rational calculus, the application of which will maximize cost-effectiveness and personal freedom. ${ }^{226}$

As one of its foundational premises, neo-liberalism thus shares with other forms of radical economism a desire to replace political action and deliberation by economic rationality. This is a matter of efficiency but also of principle. Since, as we already stated, neo-liberals associate, in a dichotomous fashion, politics with coercion and economic

\footnotetext{
224 Ibid.

${ }^{225}$ See for example Daniel Little, "Rational-Choice Models and Asian Studies," The Journal of Asian Studies 50, No. 1 (February 1991): 39.

${ }^{226}$ Max Neiman and Stephen J. Stambough, "Rational choice theory and the evaluation of public policy," Policy Studies Journal 26, No. 3 (September 1998): 450.
} 
action with freedom, they consider it a necessity for the moral improvement of society to "divide the space in which social life takes place so there is a maximum economic and a minimum political sector." 227 Their intention might not be malevolent, after all their contention with the political sphere is primarily directed at the coercive aspect of politics. Nevertheless, whatever their initial intention, by framing public deliberation as an 'exchange' of ideas, voting as rent seeking, and action as the simple result of a costbenefit calculus, they throw the baby with the bathwater they evacuate the political as such and not only coercive sovereignty.

Neo-liberals' attitude towards public intervention is somewhat paradoxical. In most cases, advocates of a market-based order oppose collective action and support a policy of isolating and restraining politics. After further analysis of their arguments however, their position appears more equivocal and strategic. In fact, neo-liberal thinkers often welcome a large degree of public intervention as long as it serves to create and protect the emergence of new markets and of a economic order. Again, the Chicago School is a prime example of the essence of neo-liberalism. After having opened his famous book Free to Choose, Milton Friedman has no qualms advocating constructivism and social engineering to institute such an anti-political order. The objective might be laissez-faire, but the means certainly are not:

Our society is what we make it. We can shape our institutions. Physical and human characteristics limit the alternative available to us. But none prevent us, if we will, from building a society that relies primarily on voluntary cooperation to organize both economic and other activity, a society that preserves and expands human freedom, that keeps government in its place, keeping it our servant and not letting it become our master. ${ }^{228}$

\footnotetext{
${ }^{227}$ John McKinney, "Frank H. Knight," in Warren J. Samuels (ed.), Op. Cit. (East Lansing: Michigan State University, 1976), 196.

${ }^{228}$ Milton Friedman and Rose Friedman, Free to Choose, A Personal Statement (New York: Avon Books, 1980), 29.
} 
Friedman's call to action is a far cry from Hayek's reverence for millennial traditions and practical knowledge. Hayek was looking backward, appealing to the pessimism of classical liberalism, denouncing the folly of modern rationalism and of action understood as creation (poesis). Friedman's form of economism, less philosophical and less selfconscious, follows the modern tradition of understanding progress as structural transformations and showing optimism towards human agency.

Engaged, in their beginnings in a contest against the Keynesian orthodoxy, neoliberals rapidly developed market proselytism as both a form of propaganda for the masses and as rhetoric for the elite. The Chicago School figureheads are very much aware of the normative component of their ideas and many accept readily the role of economists as preachers. ${ }^{229}$ Chicago School's representative voices like Frank H. Knight and Milton Friedman are clearly conscious of the limits of individualist methodology and that their analytic tools are intertwined with a prescriptive strategy. However, they consider the assumption of individual rationality necessary to defeat statism and promote individualism as a social norm. In his own words, Knight sees reality as being "not what is logical, but what it suits our purposes to treat as real"230 and is looking for the "basis of a propaganda for economic freedom." ${ }^{231}$ Both Friedman and Knight recognise the importance of collectivist methodology ${ }^{232}$ (the influence of social structures and collective agencies on the individual) but occult all collective reality in their own method to advance their normative strategy of 'economic education':

\footnotetext{
${ }^{229}$ Stigler, George J., The Economist as Preacher, and Other Essays (Chicago: The University of Chicago Press, 1982), 3-13.

${ }^{230}$ Frank H. Knight, "The Ethics of Competition," cited in Warren J. Samuels (ed.), Op. Cit., 365

${ }^{231}$ Frank H. Knight, "Theory of Economic Policy and the History of Doctrine," cited in Ibid., 368

${ }^{232}$ Warren J. Samuels , "Further Limits to Chicago Scholl Doctrine," in Ibid., 403
} 
Chicago economics, following Knight, is a science infused with a social control idea. Chicago economics is social engineering at its most subtle level. It is part of the social processes which socialize man along certain lines and not others. The Chicago School economist is both investigator and pleader, both observer and participant. The market is not a mere object of study; it is something which must be shown to work, and evidence to the contrary, while admitted, is narrowly and safely circumscribed. ${ }^{233}$

At the heart of the Chicago School's project lies the endeavour to promote 'rational economic man' and 'free markets' as new founding myths to legitimate the status quo and move institutions towards their ideal. Ironically, in the process the School itself acts like the social forces it decries. Some have even discerned religious elements in neo-liberal doctrines and practices. ${ }^{234}$

To be fair, not all advocates of radical economism endorse explicitly a unidimensional approach to society and human reason. Gordon Tullock, for instance, the principal associate of Buchanan and a founding figure of public choice theory, acknowledges the caricatural character of the homo oeconomicus model, and recognises the fact that humans possess plural selves as well as the impossibility of reducing all life to economic relations. Nevertheless, Tullocks's good words for perspectivism and pluralism do not reflect the enterprise for which he sets out. A few pages following these open-minded remarks, Tullocks explains public choice's basic tenets by reciting the mantra of radical economism: choice is only individualistic, the application of economic optimality to politics is a value-free endeavour, politics can and must be studied the same

\footnotetext{
${ }^{233}$ Warren J. Samuels , "Chicago Doctrine as Explanation and Justification," in Ibid., 382-383

${ }^{234}$ See for example Robert H. Nelson, Economics as Religion, from Samuelson to Chicago and Beyond (University Park: The Pennsylvania State University, 2001).
} 
way as economics, and, above all, there is no metaphysical difference between the economic and the political. ${ }^{235}$

But political science is certainly not the only discipline which has received pressure from outside and within to adopt an economistic framework. There are indeed other fronts in the advance of economism. As with political reality, we can discern in late modernity a movement seeking to re-envision history and foreign cultures through the lens of the market. If human rationality can be generalised across the different academic disciplines and across the entire discursive field, why not across time and space? Similarly to the distinction that we made between classical liberalism and neo-liberalism, this economistic tendency in the field of history is expressed more or less radically in its approach, some historians are open to some form of ontological pluralism but stress the primacy of one or many economic factors in institutional determination and change (in the manner of Marx or Rousseau) while others reinterpret the other historical periods or the other cultures through the paradigm of the free market and the homo oeconomicus. Again, neo-liberals place the burden of proof on those maintaining transitivity in human rationality, in this case on those who pretend that the importance of the economic realm changed substantially over time and on those who claim that the market as we know it did not always exist or is not ubiquitous.

In the field of history, the application of microeconomic and neo-liberal models has been spearheaded by a school self-baptised as the new economic history or cliometrics. Deriving from the Chicago School, cliometrians understand their new science

\footnotetext{
235 James M. Buchanan and Gordon Tullock, The Calculus of Consent, Logical Foundations of Constitutional Democracy (Indianapolis: Liberty Funds, 2004), 19-35.
} 
as a "form of applied neo-classical economics." ${ }^{236}$ Keen on formal mathematical models, cliometricians approach earlier economies with the premise of neo-liberal subjectivity. The disciples are called to search for data compatible with the said model, not to acquaint themselves with the culture or Zeitgeist under study. Typically, new economic history "starts with a formal model of some aspect of economic behaviour, assemble data for use in the model, and draw conclusion by joining the data and the model."237 The birth of cliometrics is commonly traced back to 1958 when Conrad and Meyer published a controversial article on American slavery seeking to demonstrate the economic profitability of the institution and its effect on the economy of American south ${ }^{238}$. In the 1960 s and 1970 s, the movement swept the profession, passing from the margin to the centre to become in the 1980 the new orthodoxy of the discipline ${ }^{239}$. What is troubling with cliometrics is of course not that it seeks to understand economic history through the aid of economic theory; the subject matter makes this relation natural and evident. What is more problematic is that it ascribes to ancient and pre-capitalist economies the model of the 'rational economic man' and that of the free market. In this respect, the so-called new economic history lends its support to the positions called formalism and modernism in economic history and economic anthropology. These economistic positions, it must be specified, existed well before neo-liberalism. In the beginning of the $20^{\text {th }}$ century, a debate raged between the substantive conception of ancient economy, championed by Polanyi, and the formalist conception lead by Rostovtzeff. Polanyi, opposing the function and nature of classical and modern economies, defines the former as directed to the

\footnotetext{
${ }^{236}$ Peter Temin (ed.), New Economic History (Baltimore: Penguin Books, 1973), 8.

${ }^{237}$ Ibid.

${ }^{238}$ A. H. Conrad and J. R. Meyer, "The Economics of Slavery in the Antebellum South," Journal of Political Economy 66 (1958): 95-130.

${ }^{239}$ Robert Whaples, "A Quantitative History of the Journal of Economic History and the Cliometric Revolution," The Journal of Economic History 51, No. 2 (June 2001): 289-301.
} 
provisioning of society, an economy of use where the economic motive was limited through integration in social relationships. ${ }^{240}$ Defending a vision akin what was presented in the first chapter of the present thesis, Polanyi sees ancient economy as essentially embedded in the community. The formalist position, by contrast, considers that ancient economy, while reflecting a more primitive development, is based on private markets and functions on the same economic rationality as the one ruling modern markets. In both cases, the formalists argue, the economy can be defined as the market-based allocation of scarce resources. In the first instance the economy is a mean, in the former an end. As Polanyi summarises, the two positions are based on two diametrically opposed views of what is to be considered economic: on the one side a mentalist abstraction of economic choice processes and rules based on the modern reality of the self-regulating market, and on the other hand a larger definition of the economic as an institutionalised process through which one society acquires its "means of material want satisfaction." 241 If we listen to one of the most famous representatives of the formalist position, the very existence of social institutions revolves around economic calculations and choice processes: "private benefits or costs are the gains or losses to an individual participant in any economic transaction. [...] If the private costs exceed the private benefits, individuals ordinarily will not be willing to undertake the activity even though it is socially profitable." ${ }^{242}$ Differing in degrees of liberality but not in kinds of rationality, ancient and modern economies are viewed by formalists and neo-liberal cliometricians as substantively the same. It is a mistake, in their opinion, to oppose the logic and function

\footnotetext{
${ }^{240}$ Karl Polanyi, Op. Cit., 57.

${ }^{241}$ Karl Polanyi, "The Economy as Instituted Process," in Karl Polanyi and others, Trade and Market in the Early Empires, Economies in History and Theory (New York: The Free Press, 1957), 243.

${ }^{242}$ Douglas C. North and Robert Paul Thomas, The Rise of the Western World, A New Economic History (Cambridge: Cambridge University Press, 1973), 2-3.
} 
behind the trade of Mycena or the Roman Empire from that of Wall Street. The principle behind market economy is seen as universal, both in terms of time and culture:

Tales of the adventure of homo economicus in unlikely places are beginning to accumulate, in places like nineteeth-century India for example, or medieval Europe, or declining Rome. But it would be premature to announce his conquest of those places. Still, the frontier of cliometrics is the wide world beyond America, or indeed, beyond Europe. $^{243}$

A similar market-oriented conception of the economy will also come to prevail in the field of economic anthropology. In the case of anthropology, culture would be often tossed aside by neo-liberals as a shallow reflection of rational utility seeking (the school of developmentalism) when it was not rejected by orthodox Marxists in the name of another popular form of economism: the mechanical reading of class interests. ${ }^{244}$ Like in the case of the school of public choice, new economic history and its anthropological counterpart (also known as new institutional anthropology) are not always formally affiliated with the University of Chicago but their disciples readily acknowledge its legacy and their intellectual debt. ${ }^{245}$

If we decided to emphasise neo-liberalism as the paramount example of radical economism, it should be noted that its historical competitor, Keynesian Interventionism or Fordism, represents no genuine alternative. It is true that Keyesianism does not reject the state as a positive instrument and is, in comparison to neo-liberalism, less aggressive in its rejection of political action and deliberation.

\footnotetext{
${ }^{243}$ Donald N. McCloskey, "The Achievements of the Cliometric School," The Journal of Economic History 38, No. 1 (March 1978): 24-25.

${ }^{244}$ See Clifford Geertz, "Culture and Social Change: The Indonesian Case," Man, New Series 19, No. 4 (December 1984): 511-532 and Joel S. Khan, "Towards an History of the Critique of Economism: The Nineteeth-Century German Origins of the Ethnographer's Dilemma," Man, New Series, 25, No. 2 (June 1990): 230-249.

${ }^{245}$ For instance, while Fogel did not study at Chicago (even though he later occupied a research position there), he has stated that George J. Stigler was his most influential teacher at Johns Hopkins University. http://nobelprize.org/economics/laureates/1993/fogel-autobio.html (accessed May 19 ${ }^{\text {th }}, 2006$ ).
} 
Beyond the appearance of opposition, however, the two competing schools represent merely the two sides of the same coin. On one side, Keneysians advocate a social form of economism which uses the state to manage the population from the macro perspective of society. On the other side, neo-liberals reject the Social in favour of the individual.

Notwithstanding this affinity, neo-liberalism might be said to be more aggressive and utopian in its economism. By conceiving everything as markets, entrepreneurs and consumers, neo-liberalism encourages a permanent and limitless reconfiguration of reality along economic lines. It elevates the market to the position of permanent economic tribunal in front of which all reality must justify itself. ${ }^{246}$ Furthermore, neo-liberalism can be said to be more radical because it pretends to be able to replace one of politics' traditional and most fundamental domains: order. The outlook of Keynes's theory might be economistic, yet its objectives and scope of action remains mostly associated with the traditional economic sphere, the management of economic crisis, and the economic welfare of the population, amongst other things. With neo-liberalism, in contrast, one deals not with the economy as a system of production, exchange, and consumption but with the economic as self-ordered life.

To conclude this chapter, a word should be written on the zealousness expressed by many neo-liberals, an overt optimism which can perhaps explain their unmitigated use of language. Like other new intellectual movements, and especially those of rationalistic outlook, the Chicago School and its various branches are filled

\footnotetext{
${ }^{246}$ Michel Foucault and others, Naissance de la biopolitique: cours au Collège de France (1978-1979) (Paris: Gallimard -Seuil, 2004), 253.
} 
with assurance and faith. We find in these writings not the morosity usually associated with number crunchers and thick glasses economists but the spirit of adventure of pioneers, as if neo-liberal scholars went on a mission filled with the spirit of duty, as if they were told: onward market soldiers, the world is to be reorganised, all facts are to be revisited, a new Archimedean point has been found! Order can be reinstalled! 
IV

The preceding chapter provided a picture of the radical and totalising character of neo-liberal economism. In the two following sections, we will advance further into our analysis of the question of radical economism by approaching the matter from two specific angles: the sociological implications of neo-liberalism with regards to questions of subjectivity and power, and the philosophical significance of the phenomenon of radical economism in terms of the integrity of the political sphere and the possibility of political existence.

With Foucault as our main guide, we will try to decipher how neo-liberalism brings about a new form of governmentality, that is a theory and practices of governance based not on the state or civil society but on the governmental ideal of ruling 'at a distance' ${ }^{247}$ In this horizontal model of rule, people are governed as empowered though normalised selves, subjects of choice and responsibility who are often represented through the paradigmatic figures of the consumer and the entrepreneur. In order to make clear the connection between this governmental model and neo-liberalism, we will first highlight the form of subjectivity implied in the theory of another child of the Chicago School of Economics, Gary S. Becker, and his conception of human as human capital. Consequently, we will explore with Foucault how this subject is mobilised to play an active role in his/her own governance and how sovereignty and discipline serve as parapets of self-governance, fulfilling the function of normalising technologies insuring that freedom of choice is handed down to a well tempered and 'civilised' subject. A sociological analysis of radical economism is necessary because neo-liberalism does not only reject the political, but also claims to represent an economic ordering of society.

${ }^{247}$ Peter Miller and Nikolas Rose, Op. Cit.: 9. 


\section{Governmentality: government through proxy}

Before advancing any further in our analysis, it might be useful to first differentiate the Foucauldian analysis of neo-liberalism as a form of governmentality from the usual critique of neo-liberalism as a right-wing ideology advocating a minimalist state, cuts in social programs and the free flow of capital. ${ }^{248}$ Of course, neo-liberalism consists partly in the promotion of such policies, but our interest lies elsewhere.

Beyond the usual critique of neo-liberalism as policy and ideology, this radical movement can also be assessed as a strategy and a set of practices of rule, as a form of what Foucault called gouvernementality (governementalité). But what exactly is governmentality, a term often used as academic currency but not always defined or explained? Polysemic, the word governementality can only be explained through a series of definitions. First, it is interesting to know that Foucault coined this neologism by uniting the two words gouvernement and mentalité. This term thus relates to both a mentality and a practice of rule. Governmental programs are never completely theoretical and are always presupposing, attached to, or demanding technologies of rule that implement their models. Rose makes this point elegantly when he says that governmental thought always tries to "insert itself into the world by 'realizing' itself as a practice."249 In this sense, governmentality is inherently technological, neither completely abstract nor completely realist. As all technological enterprises, it reveals itself as an attempt, partly utopian to be sure, to co-penetrate thought and action. For Miller and Rose, this

\footnotetext{
${ }^{248}$ Wendy Larner, "Neo-liberalism: Policy, Ideology, Governmentality," Studies in Political Economy 63 (Automn 2000).

${ }^{249}$ Nikolas Rose, "Governing "advanced" liberal democracies," in Graham Burchell and others (eds.), The Foucault Effect, Studies in Governmentality (Chicago: The University of Chicago Press, 1991), 41.
} 
technological dimension is expressed by an eternal optimism about the prospect of administrating reality better, more efficiently, and through its belief that reality is programmable. ${ }^{250}$ Reality is represented as being open to and in need of intervention, and the technologies that are implemented fulfil that very scheme. For instance, rational choice grids are instrumentalised in schools, hospitals, and other environments as 'performance indicators' which in time bring these institutions closer to the enterprise form and market logic. On another level, technological governmentality interweaves thought and intervention ruling through a multiplicity of seemingly mundane techniques such as: methods of calculations, examination or training, the appearance of self-help guides and self-completed tests, campaigns for self-esteem, repeated calls for a more responsible and personal management of risk, vigilante actions at borders and so forth. ${ }^{251}$ Part of neo-liberalism's force is that it acts as a self-fulfilling prophecy:

If political rationalities render reality in the domain of thought, these 'technologies of government' seek to translate thought into the domain of reality, and to establish 'in the world of person and things' spaces and devices for acting upon those entities of which they dream or scheme. ${ }^{252}$

Seeking to rationalise means and ends, neo-liberal technologies of government bring ever closer the limit between their model and the reality they work upon.

'To govern' also implies that the subject of rule is not completely dominated, that he or she possesses some space of freedom of choice, a margin of liberty. In this sense, Foucault distinguishes government from domination when he further defines government

\footnotetext{
${ }^{250}$ Peter Miller and Nikolas Rose, Op. Cit.: 4.

${ }^{251}$ Barbara Cruikshank, "Revolutions within: self-goverment and self-esteem," in Barry, Andrew and others (eds.), Op. Cit., 231-252 and Pat O'Malley, "Risk and responsability," in Graham Burchell and others (eds.), Op. Cit., 189-208.

${ }^{252}$ Peter Miller and Nikolas Rose, Op. Cit.: 8.
} 
as the "conduct of conducts." definition to bypass the modern obsession with the state and the conception of power as inherently negative and restraining: "cette notion [gouvernement] étant entendue au sens large de techniques et procédures destinées à diriger la conduite des homme.

Gouvernement des enfants, gouvernement des âmes ou des consciences, gouvernement d'une maison, d'un État ou de soi-même."254 There is a negative dimension to governing because it structures the field of action of other subjects. ${ }^{255}$ But in a Hegelian fashion, this negation shapes reality and gives form and identity to the subject; power creates more than it limits.

One must not look for the presence of governmental power primarily in the courts, the legislatures, or in the antechambers of the state, but in the proxy zone where, without repression or interdiction, we are encouraged to reason and act in certain ways.

Government steers a person in one direction and structures that person's field of action by mobilising instead of negating freedom of choice. It represents this "point of contact where techniques of domination or power and technique of the self interacts." ${ }^{256}$ To govern is thus antithetical to top-down forms of sovereignty or uni-directional models of rule and entails the constitution of a subject, both active and governed. This explains why part of the phenomenon of neo-liberal governmentality cannot be explained solely through the traditional vocabulary of political philosophy. Analytics of governmentality

\footnotetext{
${ }^{253}$ Michel Foucault, "Le sujet et le pouvoir," in Dits et écrits, Vol. IV 1980-1988 (Paris: Gallimard, 1994), 237.

254 "This notion being understood in the wide sense of techniques and process seeking to direct the conduct of men. Government of children, government of souls or consciousnesses, government of a house, a state or of one-self." [my translation] Michel Foucault, "Du gouvernement des vivants," Michel Foucault, Dits et écrits, Vol. IV 1980-1988 (Paris: Gallimard, 1994), 125.

${ }^{255}$ Maria Bonnafous-Boucher, Un Libéralisme sans Liberté, du terme "Libéralisme» dans la pensée de Michel Foucault (Paris: L'Harmattan, 2001), 81.

${ }^{256}$ Colin Gordon, "Governmental rationality: an introduction," in Graham Burchell and others (eds.), $O p$. Cit., 20.
} 
reveal a different facet of power from the understanding canonised by political science, sociology and philosophy: a microphysics of power passing through a multiplicity of channels and through a plethora of technologies, a kind of power more horizontal than vertical (rhizomatic to use Deleuze's concept), a transversal power for which the dichotomies private/public, political/economic, state/civil society lose their heuristic power. ${ }^{257}$ In relation to our thesis, this conception of government sheds light on liberalism and neo-liberalism as mentalities and technologies of government trying to reconcile the necessity of rule with the necessity of a free market and a free subject for advanced capitalist economy. Seen from the perspective of governmentality, neo-liberalism is more about power than about finances. Concerned with order, neo-liberalism is thus revealed as "both a political discourse about the nature of rule and a set of practices that facilitate the governing of individuals." 258 This relatively novel approach to the topic explains why neo-liberalism might means less government in the sense of 'less state', but does not necessarily means less governance. ${ }^{259}$

Central to a neo-liberal mode of government is the constitution of a subject integrating economic rationality and behaviour. In other words, the neo-liberal subject internalises a market-based framework from which to judge the world. In the last chapter, much time was spent on describing how neo-liberalism analyses all questions from an economistic perspective. But to say that an actor's behaviour and motivations are amenable, epistemologically, to economic analysis is also to imply that the subject in question is, in one form or another, ontologically economic. It follows that this actor, be it an individual, a social institution or the state, can not only be studied economically but

\footnotetext{
${ }^{257}$ Peter Miller and Nikolas Rose, Op. Cit: : 1-8.

${ }^{258}$ Wendy Larner, Op. Cit.: 6.

259 Ibid.: 12 .
} 
also be made to function in an economic fashion. In this vein, neo-liberal governmentality is based on specific forms of subjectivity and freedom it fosters and requires. More precisely, it represents a form of power based on fostering, empowering and mobilising this choosing and interested subject.

But first things first. Before it can act as a reform program, neo-liberal governmentality projects a representation of the self and of social reality as a whole; in other words, it draws a topography and schematisation of the world and how it ought to be governed. ${ }^{260}$ The neo-liberal definition of an 'economy' here breaks with the Keynesian understanding which views the economy from the elevated and macro perspective of the Social. It also parts with the legacy of classical liberalism which, as we already explained, categorised 'economic man' as a natural motivation of human beings. Within the classical framework, governing was economic insofar as it traced a limit to the action of the state and criticised the megalomania of raison d'état. Economic reality was to be laissez-faire, to be preserved, but it could not represent a universal and operational principle of government since its natural character also made fortuitous any plan to foster, reproduce or even mimic its logic. Neo-liberalism's new conception of the economy, its generalisation of the economy and its constructivism, can be understood as a desire to govern more fully and more rationally; as Rose says paraphrasing Nietzsche, it emerges from a "will to govern". ${ }^{261}$ Before being governed as consumers, entrepreneurs and partners, individuals must first be judged and assessed from an individual rather than social level, and they must be conceptualised as sharing the same market-based rationality. Under neo-liberalism, reality is represented as economic and the economy is

\footnotetext{
${ }^{260}$ Peter Miller and Nikolas Rose, Op. Cit.: 6.

${ }^{261}$ Ibid.: 4.
} 
in turn understood as an unlimited network of markets and consumers in perpetual reconfiguration and construction. ${ }^{262}$

\section{Individualising control}

By disseminating market values to all institutions and individuals, neo-liberalism ultimately seeks to integrate the market to the self as the standard from which to evaluate all choices and behaviours. The world is to be seen as a multiplicity of markets, from the market of love and beliefs to the market of criminality and softwood lumber. People are told that they live in an active society, where they must finally come to maturity, reject the idea of society, embrace the iron law of supply and demands and accept their responsibilities as market players and partners. The key words of neo-liberal governmentality are choice, freedom, and responsibility. While its rationality, its logic, remains the same, neo-liberal government's forms of intervention and discourse are multiple and adaptative: "Neo-liberal strategies of rule, found in diverse realms including workplaces, educational institutions and health and welfare agencies, encourage people to see themselves as individualised and active subjects responsible for enhancing their own welfare. ${ }^{263}$ The expansion of the economic is thus not only apparent across spheres of activity, academic disciplines, or in our outlook towards history, but also in the conception we hold of individuality and society, and the encouragement of a specific form of individual subjectivity and behaviour grounded in economic rationality. With regards to politics, neo-liberal subjects are encouraged to behave as consumer-citizens, engaging in political debates and decisions within an economistic mindset, voting as they

\footnotetext{
${ }^{262}$ On the discursive character of governmentality see Ibid: : 4-6.

${ }^{263}$ Wendy Larner, Op. Cit.: 13.
} 
shop and shopping as if it was political. ${ }^{264}$ Likewise, in the model of politics construed by Chicago theorist of human capital Gary S. Becker's, interest and pressures groups are seen as the important players of the political game. According to Becker, these interested participants, whether individual or collective, enter the public arena with a certain political capital they seek to maximise. They compete for influence and public benefit the same way an economic agent compete for capital and profit. Becker and other economistic theorists of politics regard the public sector like as a black box. To them states are public markets whose primary function is to factor-in the influence of the different participants and maximise political utility accordingly, within the constraint of the scarcity of political resources (feasible taxes, realistic subsidies, etc.). ${ }^{265}$ Unsurprisingly, the main concern of these theorists is not substantive but methodological. Their minds are primary occupied with finding how to adjust and translate the mathematical functions and the technical terms used.

Since individuals' choices are seen as optimal when calculating costs and benefits, neo-liberal government values above all other norms a form of agency akin to private consumption. In the end, neo-liberalism advances the idea that utility-maximising individuals (from this perspective, everybody) would make more enlightened and fruitful choices in an environment reproducing the structure of the capitalist free-market. The neo-classical conception of the mind as a benefit maximisation machine is also constitutive of neo-liberalism foundations:

The second [presupposition of neo-classical theory] is a conception of the mind, the mind of the autonomous individual who, in his numbers, postulates the

\footnotetext{
${ }^{264}$ It is interesting to note that even the resistance to neo-liberalism is often formulated in the language of consumerism. For example, the last decade has seen the popularisation of ethical and fair-trade consumerism.

${ }^{265}$ Gary S. Becker, Theory of Political Behavior (Chicago: University of Chicago Press, 1981), 31-32.
} 
economy of private choice and free exchange. Mind is understood as approximating the perfect instrument of pleasure and pain, work dissatisfaction and consumption satisfaction, utility optimising, preferences balancing, cost minimising calculus with cost differentials, opportunity sets, wants, utilities or preference relationships taken as a given. ${ }^{266}$

Albert O. Hirschman, who critiqued economic theory as omitting relevant non-economic forms of behaviours like collective political action, offers this concise yet comprehensive definition of the neo-liberal self:

Economics as a science of human behaviour has been grounded in a remarkably parsimonious postulate: that of the self-interested, isolated individual who chooses freely and rationally among alternative courses of actions after computing their prospective costs and benefits. ${ }^{267}$

Revolving around this axis of choice, interest and economic rationality, the neoliberal subject is mobilised and encouraged to work and maximise himself or herself as a compound of human capital. Foucault uses the term 'subject' purposefully, to stress the active stance of late modern governmentality where individuals are both subjected to power and made subject, both normalised and individualised. Increasingly responsibilised, neo-liberal subjects are empowered to make choices in their health, education, employability, and so forth. Neo-liberal governmentality criticises the inflexibility and the absence of individual motivation characteristic of welfare society. Instead of governing population as a homogeneous mass, neo-liberalism attempts to govern through the choices of individuals.

To say that the neo-liberal subject is economic in nature is of course too general a qualification. To be more precise, one could say that if the archetypes of classical liberalism, welfare interventionism, and socialism are the worker and in a more limited

\footnotetext{
${ }^{266}$ Robert A. Solo, "Neoclassical Economics in Perspective," in Warren J. Samuels (ed.), Op. Cit., 54 ${ }^{267}$ Albert O. Hischman, "Against Parsimony, Three Easy Ways of Complicating Some Categories of Economic Discourse" cited in David Kiron, "Economic and the Good, I: Individuals," in Frank Ackerman and others, (eds.), Human Well-Being and Economic Goals (Washington: Island Press, 1997), 165
} 
importance the capitalist (a producer and a possessor of surplus value), the paradigmatic neo-liberal identities are the consumer and the entrepreneur.

In relationships with others, the neo-liberal subject appears as a consumer, evaluating its choices in a maximising economistic grid. In neo-liberal modernity, consumer rationality is projected as underlying all other dimensions and complexes of the neo-liberal self, which are themselves projected as 'life-styles', 'identities' and 'skills' that can be chosen, consumed and agenced in a perfectible manner. Unlike classical liberalism, neo-liberalism is not content with barely securing from the state a space of liberty. It brings the idea of spontaneous order to another level by seeking not only to reconcile government with freedom but to govern by creating, working through or utilising freedom. ${ }^{268}$ Because of the central place given to markets and rational (read economic) choice, the boundary between a consumer decision and the decision leading to a vote, a civil union, a contract, or any other decision becomes blurry. Again, the difference between classical liberalism and neo-liberalism comes to the fore: while early liberalism sought to govern the social, the neo-liberal project seeks to govern its subjects more directly, by mobilising them as 'responsibilised' and empowered agents. ${ }^{269}$ The market stops being a material institution and is personally integrated, becoming a sort of filter of intelligibility, a nexus linking the working, desiring and willing self to the external world. In sum, the consumer becomes more than an identity, this role is assumed as the way a sensible and well constituted person engages reality and responsibilities. Correspondingly, the economistic imperialism typical of radical economism is not

\footnotetext{
${ }^{268}$ Mitchell Dean, "Liberal government and authoritarianism," Economy and Society 31, No. 1 (February 2002): 38 .

${ }^{269}$ Barbara Cruikshank, "Revolutions within: self-government and self-esteem," in Barry, Andrew and others (eds.), Op. Cit., 234 and Nikolas Rose, "Governing "advanced" liberal democracies," in Ibid., 57-58.
} 
restricted to the state and the social sciences but extends to the individual who must apply an economistic cost/benefit framework to all his or her activities and behave as if life itself was comprised of a multiplicity of markets. ${ }^{270}$

Towards his or her own person, the neo-liberal subject often adopts the stance of an entrepreneur, maximising not only the profit that can gain from his or her engagements with other people and institutions, but also his or her own potentialities. Neo-liberal governmentality responsabilises the subject to be engaged in his/her own governance by harnessing a concern for his/her own perfectibility and maximisation to an increased freedom of choice. Confronted with the image of an ever changing world and a very competitive environment, the individual must constantly work on him or her self to succeed or simply catch up to the demands of the marketplace. Like social reality in general, the self is thus seen as a malleable and improvable capital, a capital which can be supplemented through different strategic choices and techniques like continuing education, the improvement of professional skills, cosmetic surgery, individual management of one's risks, care for one's health and psychological self-help. In sum, neo-liberal governmentality applies, to the individual, paradigms of strategic decision making hitherto reserved to macro-level realities such as the firm. The individual is thus an entrepreneur of one's self and an individual-enterprise. The following passage might be long, but it certainly captures the specificity of neo-liberal governmentality as an individualising and radically economistic regimen of rule:

Whereas classical liberalism articulated a distinction, and at times even a tension, among the criteria for individual moral, associational, and economic actions (hence the striking differences in tone, subject matter and even prescription between Adam Smith's Wealth of Nations and his Theories of

\footnotetext{
${ }^{270}$ Graham Burchell, "Liberal government and techniques of the self," in Ibid., 27-29.
} 
Moral Sentiments), neo-liberalism normatively constructs and interpellates individuals as entrepreneurial actors in every spheres of life. It figures individuals as rational, calculating creatures whose moral autonomy is measured by their capacity for "self-care" - the ability to provide for their own needs and service their own ambition; it relieves the discrepancy between economic and moral behavior by configuring morality entirely as a matter of rational deliberation about costs, benefits, and consequences. ${ }^{271}$

This reflexivity characteristic of neo-liberal rule, this perpetual working on one's self, is not directed like the askesis of previous ages towards ascetic self-control, virtue, happiness and tranquillity, but at the creation of a human capital capable of being competitive in the marketplace of life. This is coherent with the late modern understanding of nature and humanity: nothing is permanent, time is historical, and humans are creators of values and of themselves. ${ }^{272}$

In comparison, Smith's conception of the spontaneous order points to an everchanging reality, but a natural reality nonetheless. In his account of the invisible hand of human passions, whether acquisitive or not, Smith portrays nature like Machiavelli, albeit in a more positive light. Nature is similarly described as a pre-rational flux which reveals its power when free from human action; but contrary to Machiavelli, it is not a chaotic, vengeful, or destructive fortuna, but a pre-social harmony rendering possible social virtue even in the less civic oriented individuals and making possible sociability even in the selfcentred life of the city. The spontaneous order of the market and its reflection in the selfgoverning homo economicus on the opposite are addressed by neo-liberals as a constructed reality. In its later version, homo economicus is a manipulable subject who is

\footnotetext{
${ }^{271}$ Wendy Brown, "Neo-liberalism and the End of Liberal Democracy," Theory and Events 7, No. 1 (2003): 4.

${ }^{272}$ George Grant, Time as History (Toronto: University of Toronto Press, 1995).
} 
fostered by market arrangements and who, in turn, reacts to its environment. ${ }^{273}$ As Colin Gordon reflects, economic government here "joins hands with behaviouralism."274

Consider in this light Becker's view of human capital and the neo-liberal understanding of work. With the Chicago School occurs in economic theory a radical shift in the perspective from which the phenomenon of work is addressed. The classical theory of work understood the worker as a partner in the double sided process of production and consumption and regarded work as only one part of a complex process of capital accumulation, investment, production, etc. This understanding of work is judged lacking by neo-liberal theorists like Becker since it relies on a macro-level and sociallyrooted conception of the economy they explicitly reject. Remember that the Chicago School enlarged the concept of the economy by conceptualising it as a form of maximising rationality and decision process in a world of scarcity instead of the process of production and exchange of goods and services. As neo-liberal theorists internalise the economic in general as a form of rationality, they also internalise work and begin to study this activity from the perspective of the worker. Neo-liberals reject the birds-eye-view perspective which understands work as the worker selling his or her labour power or as participating in the process of production. For American neo-liberals, this is an abstraction which fails to grasp the reality of the worker. From the standpoint of the worker, neo-liberals argue, a salary is not the added-value or the price of one's labour power, but simply revenue one can gain. ${ }^{275}$ The capital from which this salary is a revenue is composed of inborn and acquired competencies and assets, it is a machine

\footnotetext{
${ }^{273}$ Michel Foucault, Naissance de la biopolitique, Cours au Collège de France. 1978-1979 (Paris: Gallimard Seuil, 2004), 274.

${ }^{274}$ Colin Gordon, "Governmental rationality: an introduction," in Graham Burchell and others (eds.), $O p$. Cit., 43.

${ }^{275}$ Michel Foucault, Op. Cit., 230.
} 
creating a flux of salary. ${ }^{276}$ As Foucault clarifies, the neo-liberal model of the homo oeconomicus differs from its classical counterpart in that it is no longer a partner in economic exchanges but an entrepreneur of one self: "substituer à chaque instant, à l'homo oeconomicus partenaire de l'échange, un homo oeconomicus entrepreneur de luimême, étant à lui-même son propre capital, étant pour lui-même son propre producteur la source de [ses] revenus." 277 In a similar manner, the consumer is not seen as another social identity but as another facet of the same 'machine'. ${ }^{278}$ The consumer, for human capital theorists like Gary S. Becker, is not to be opposed to the worker since the consumer is also an entrepreneur of one-self, producing, out of the same rationality and the same human capital, a satisfaction. ${ }^{279}$ Moreover, as with all machines, this compound of human capital can be more or less efficient; most often, it follows a curve of experience and obsolescence. Foucault illustrates this individuation of work as the functioning of 'competence-machine' with his usual analytic detachment:

[...] il faut considérer que la machine constituée par la compétence du travailleur, la machine constituée par, si vous voulez, compétence et travailleur individuellement liés ensemble, va tout au cour d'une période de temps être rémunéré par une série de salaires qui vont, pour prendre le cas le plus simple, commencer par être des salaires relativement bas au moment où la machine commence à être utilisée, puis vont augmenter, puis vont baisser avec l'obsolescence de la machine elle-même ou le vielliessement de l'individu en tant qu'il est une machine. ${ }^{280}$

${ }^{276}$ Ibid., 230.

${ }^{277}$ To substitute at every instant to the homo oeconomicus partner in exchange, the homo oeconomicus entrepreneur of him-self, being to himself his own capital, being to himself his own producer, being to himself the source of his revenues. [My Translation] in Ibid., 232.

${ }^{278}$ As a machine producing revenues and satisfaction, human capital is inseparable from the individual processing it, and one can therefore not talk of the alienation of one's labour. See Ibid., 230.

${ }^{279}$ Ibid., 232.

${ }^{280} \mathrm{We}$ must consider that the machine constituted by the competence of the worker, the machine constituted by, if you wish, competence and worker individually linked together, will throughout a period of time be rewarded by a series of salaries which will, to take the most simple case, begin by being relatively low when the machine begins to be used, which will then rise, then will fall with the obsolescence of the machine itself or the aging of the individual as he is himself machine," [My Translation] in Ibid., 229. 
Neo-liberal governmentality thus internalises and individualises the economic and through this process brings a new reflexivity to the government of conducts. Where populations were once administered, managed and governed, through macro programs or policies, the individual is now delegated responsibilities and faces directly the dire consequences of individual inadequacies. In this neo-liberal environment, as Lemke explains from Foucault's notes, auto-containment of economic freedom is done at three major levels. ${ }^{281}$ In the first instance, neo-liberal rationality makes uniform all social phenomena by generalising all realities as economic. ${ }^{282}$ Secondly, the market-based rationality of costs and benefits calculation serves as a norm to judge all behaviours. ${ }^{283}$ In this logic, the agency behind the individual's behaviour is inoculated by reducing choice and reason in a uni-dimensional fashion. Finally, the generalisation of economic rationality opens a new mode of containment which we could call a form of 'environment alteration control'. If actors are basing their choices on the sole basis of a unique ratio (in our case the cost/benefit calculus), one needs only to alter one of these two variables to change the subject's decision or policy. ${ }^{284}$ As family policies or taxes on tobacco products reflect, 'free' consumers need only the right incentives to make the consumption choices that public good demands. In this sense, market-based rationality does not unleash unbounded choices, freedom, and subjectivity. Much to the contrary, neo-liberal governmentality's principle is precisely the mobilisation of individual choices towards self-rule and the projection of an individual subject "whose freedom is a condition of

\footnotetext{
${ }^{281}$ Thomas Lemke, "The Birth of Bio-Politics - Michel Foucault's Lecture at the Collège de France on Neo-Liberal Governmentality," Economy and Society 30, No. 2 (2001): 198-201.

${ }^{282}$ Ibid.

${ }^{283}$ Ibid: 198.

${ }^{284}$ Ibid: 201.
} 
subjection." 285

As we repeated on several occasions, neo-liberal governmentality shows rationalistic and totalising tendencies. It seeks a more thorough autonomisation of social reality and a rationalisation of the means and ends of government (privileging the use of freedom as a mean to the achievement of a government of freedom instead of discipline, law, sovereignty, etc.). However, the neo-liberal governmental utopia of a self-governed subject can only be realised in principle, never fully actualised. In reality, the self is never one; we never arrive at a final stage of liberty or administration where one can speaks of a fully realised autonomy or fully managed uni-dimensional subjectivity. What the neoliberal subject is then is a particular model of the governed self (in this case selfgoverned) which is summoned, constructed, and then taken for granted.

To state that this subjectivity of self-interest, maximisation, and choice is a model of government implies that other forms of subjectivity which do not correspond or even comply with this model can participate in its coming to being. In our case, it signifies that older modes of subjectivity such as the figure of the civic minded gentleman, the disciplined ego, the social citizen and more ancient modes of rule such as sovereignty, discipline, and pastoral dirigisme do not disappear under neo-liberalism. On the contrary, neo-liberal subjectivity and government are made possible by the support of these other social formations that stand as sedimentary foundations of a well-tempered self. Illiberal technologies of discipline and symbols of sovereignty are incorporated into liberal government. In one of his most influential lectures, Foucault explains that the rise of governmental power should not be interpreted as a rejection of discipline or sovereignty. Instead of providing yet another version of the three ages historiography, dividing social

${ }^{285}$ Mitchell Dean, "Sociology after Society," in David Owen (ed.), Op. Cit., 216. 
history into the succession of the stages of 'sovereignty-discipline-government', Foucault presents these three categories as co-existent and self-supporting. Foucault gives the imagery of a triangle explaining that one can understand a mode of power like neoliberalism as being primarily based on government but still drawing support and stability from the two other poles:

Accordingly, we need to see things not in terms of the replacement of a society of sovereignty by a disciplinary society and the subsequent replacement of a disciplinary society by a society of government; in reality one has a triangle, sovereignty-discipline-government, which has as its primary target population and as its essential mechanism the apparatus of security. ${ }^{286}$

In sum, Foucault cautions his students not to believe that the prominence of governmental rule means the complete disappearance of older structures of power (discipline and sovereignty). ${ }^{287}$ While neo-liberal government encourages our selves to conduct our lives as consumers and entrepreneurs in all contexts and situations, this represents an impossible governmental project because choice is too boundless and unstable to be the sole principle of political subjectivity. As Duverger posits, rule is Janus-faced, sharing both the power of integration and of division. ${ }^{288}$ While the neo-liberal project seeks to solve this tension by placing freedom as the vector of government, it remains dependant on discipline and sovereignty. In the case of sovereignty, the volatility of the homo oeconomicus is tempered by the injection of public forms of subjectivity into the character of the consumer. If neo-liberalism's radical ideal conceives of the homo oeconomicus as the prime political-economic identity, its real-world application demands the perpetuation of citizenship. As Valverde argued about political freedom, the neoliberal self-maximising individual is being granted freedom mostly because he or she

\footnotetext{
${ }^{286}$ Michel Foucault, "Governmentality," in Graham Burchell and others (eds.), Op. Cit., 101. ${ }^{287}$ Ibid.

${ }^{288}$ Maurice Duverger, Introduction à la politique (Paris: Gallimard, 1964), 22.
} 
"can be trusted to make the right sort of decision" 289 and because he or she has internalised limits to the field of economic action. Sovereignty is thus re-framed and internalised to support the exercise of freedom in a 'constructive spirit'. Neo-liberalism places the accent on choice, freedom and interest, but there is always the proviso of responsibility. To be responsible is to be normalised, and to possess a will and selfdiscipline strong enough to avoid radical asocial behaviours.

Discipline also remains an active principle of rule. Mechanisms and devices operating according to a disciplinary logic, from the school to the prison, produce in fact the conditions, the form of self-mastery, self-regulation and self-care, necessary to govern a population now composed of free and 'civilised' consumer-citizens. ${ }^{290}$ Paradoxical as it may seem, liberalism and neo-liberalism are, according to Foucault, made possible by a closer and more thorough disciplining of bodies and behaviours. ${ }^{291}$ In this logic, punishments continue to be exercised under neo-liberalism. The rationality behind punishment, however, is displaced. In criminal sentencing, neo-liberal forms of punishment no longer mark with a red iron the exclusion of the abnormals of society, but distribute the 'justly deserved' retribution to those who do not use responsibly their freedom. ${ }^{292}$ Crime itself is reframed in an economistic paradigm as an enterprise like any other and a condition of Pareto optimality is sought between the demands of crime and the supply of punishment. ${ }^{293}$

\footnotetext{
${ }^{289}$ Mariana Valverde, "Despotism and ethical governance," Economy and Society 25, No. 3 (1996): 364. ${ }^{290}$ Nikolas Rose, "Governing "advanced" liberal democracies," in Barry, Andrew and others (eds.), Op. Cit., 44.

${ }^{291}$ Maria Bonnafous-Boucher, Un Libéralisme sans Liberté, du terme «Libéralisme» dans la pensée de Michel Foucault (Paris: L'Harmattan, 2001), 28.

292 Pat O’Malley, "Risk and responsability," in Barry, Andrew and others (eds.), Op. Cit., 198.

${ }^{293}$ Gary S. Becker, The Economic Approach to Human Behavior (Chicago: The University of Chicago Press, 1976), 39-55.
} 
This can partly explain the supporting role played by discourses of nationalism, patriotism and citizenship in neo-liberal governmentality. We have indeed to account for the fact that economistic movements like neo-liberalism rarely reject entirely the vocabulary and institutions associated with sovereignty and political existence. This question would certainly warrant a thesis on its own and we cannot pretend to solve it in this one. With this limitation in mind, we can still advance the idea that discourses and practices of citizenship give content and direction to the neo-liberal appeal to responsibility. As Dean explains, liberalism, in all its forms, is troubled by the necessity of reconciling the subject of choice and agency it promotes and the subject of right and sovereignty enshrined in constitutions and the institution of political citizenship. ${ }^{294}$ In this regard, the problem at the heart of liberal and neo-liberal government is how to integrate and stabilise the "agencies it depends upon." 295 In most circumstances, the neo-liberal subject is called upon to decide in an economistic mindset without any regard to the country or nation he or she lives in. Brands, life-styles, costs, benefits, and such universalistic factors are the privileged parameters of decision making. Once in a while however, this person is reminded that he or she also belongs to communities of value and attachment, some of those political in name. The consumer-like subjectivity is thus grounded in space, collective identity and community. The self is to behave as a calculating and maximising consumer, but as a 'good' and well-tempered consumer nonetheless. Citizenship in its current form should therefore not be confused with genuine political existence. Effectively, neo-liberal discourses and technologies of citizenship are not associated with an opening of the public sphere, a renewed interest in republican

\footnotetext{
${ }^{294}$ Mitchell Dean, "Sociology after Society," in David Owen (ed.), Op. Cit., 217

295 Ibid., 210.
} 
citizen activity or demands for positive liberty. Rather, citizenship here responsibilises and tempers the neo-liberal subject and serves as the parapet of neo-liberal choice. In her famous research on self-esteem, Barbara Cruikshank precisely notes that technologies of citizenship aim at "persuading citizens to tie their self-interest and their fate to society voluntarily" in order to bring about stability. ${ }^{296}$ As we are constantly enticed to act as consumers and entrepreneurs-of-ourselves, we are constantly reminded of our duty towards an imagined 'public' and of our responsibility towards an idealised political collectivity. Through recurring elections, civic commemorations, political discourses and many other ways, the sense of civic belonging is maintained alive and we are prompted to re-aggregate periodically. Neo-liberal citizenship internalises boundaries of choices and identities to "produce a sense of oneness among increasingly heterogeneous populations" and reconcile the loyalties to "market economics and parliamentary democracy." 297 It is as if Rousseau's 'General Will' and the 'We' of the American Constitution remain alive and act as useful skeletons maintaining ourselves ruly. In this sense, this ideal of citizenship, based on technologies of empowerment and participation, effectively tempers the anti-social drives of individualism and consumerism. To borrow the language of Giddens, citizenship partly alleviates the disembedding effect of neo-liberal governmentality by keeping alive this civic model of ontological security. ${ }^{298}$

Classical liberalism also sought to reconcile rule and freedom. The originality of neo-liberalism is that it tries to govern primarily, and not only incidentally, through choice, individuality and subjectivity. The function of these principles

\footnotetext{
${ }^{296}$ Barbara Cruikshank, "Revolutions within: self-goverment and self-esteem," in Barry, Andrew and others (eds.), Op. Cit., 243.

${ }^{297}$ Toby Miller, The Well-Tempered Self: Citizenship, Culture, and the Postmodern Subject (Baltimore: Johns Hopkins University Press, 1993).

${ }^{298}$ Anthony Giddens, "The Contours of High Modernity," in Anthony Giddens, Modernity and SelfIdentity: Self and Society in the Late Modern Age (Cambridge: Polity Press, 1991).
} 
changes fundamentally, from negative limitations to sovereignty to the core of governmental activity. Neo-liberalism develops, in other words, a positive version of the Voluntary Submission La Boétie lamented about centuries earlier. 
In different religions of Antiquity, the stones (terminus) dividing private domains were believed to embody spirits. ${ }^{299}$ To move these stones without proper ritual was considered a serious sacrilege. Today however, in this modern age where "all that is solid melts into air," ${ }^{300}$ we can wonder if such boundaries still make sense and on what ground radical economism can be criticised. But if the distinctions between these categories of existence must be understood as at least partly constructed and if they can no longer be regarded as sacred, limits, frontiers and boundaries remain the necessary condition for meaning to emerge. The question is not whether the political and the economic exist as metaphysical entities. Existentially we do not only inhabit undifferentiated stuff but a world of people and things, and our lives can make sense only by reflecting limits, perspectives, a way of Being-in-the-world, an horizon. By reflecting on the writing of Arendt and other theorists who have been preoccupied by the question of the political, we want to make explicit the change of horizon that occurred with radical economism. Arguably, radical economism represents a retreat of the political as a mode of existence and an obscuring of its very possibility. This reflection thus seeks to shed some light on what radical economism eclipses, in other words, what is the specificity, autonomy and inextricable reality of the political that is rejected when the market takes over as the primary mode of interaction. A philosophical interpretation of radical economism is especially important since this phenomenon claims for the economic a position similar to that traditionally attributed to the political and wishes to replace politics by economics in the role of architectonic science, the organising principle of the collectivity. No longer

\footnotetext{
${ }^{299}$ Fustel de Coulanges, Op. Cit., 70-73.

${ }^{300}$ Karl Marx, The Communist Manifesto (New York: W. W. Norton \& Company, 1988), 58.
} 
seen as a mean to another end, radical economism purports that the economic is the genuine domain of freedom, the nexus between individuality and collectivity, the matrix which should organise social life and provide order. To conclude this chapter we will ask ourselves how it is possible that everything, in this radically apolitical world, seems to be open to critique and to politicisation. Returning to the distinction we made in the first chapter between zoè and bios, we will suggest that neo-liberal governmentality is a form of bio-politics through which everything is politicised as manageable, which amounts to saying that the political is vitiated of its specificity and that nothing, in fact, is specifically political any more.

Turning to Arendt for guidance is particularly appropriate considering the centrality the question of the political occupies in her writings. Arendt constantly criticised the western philosophical tradition for being incapable of grasping the significance of the political as anything other than a realm subordinated to metaphysical thought. Educated as a philosopher, she often remarked that she preferred being called a political theorist since she wrote on 'Men' rather than 'Man'. Perhaps she was marked by the fact that her mentor, Heidegger, otherwise a philosophical genius, was accomplice to the Nazi terror and, many say, a 'moral idiot'.

\section{Arendt: a dialog with Aristotle and Heidegger.}

Hannah Arendt's theory of public space and action is best understood as the projection of the Heideggerian idea of authenticity into a public space which is contrasted with the everyday realm of the Social. From this angle of analysis, it can be argued that Arendt develops an original political theory through a philosophical engagement with the concepts of Heidegger and Aristotle. Arendt's emphasis and radicalisation of the Aristotelian categories separating politics from economy, praxis from poesis, gives her 
the opportunity to present the public sphere as the source of human meaning and the actual realm of authenticity. Arendt's theory makes central Aristotle's categories, thus lifting-up the public sphere as the primordial space of appearance and meaning, while replacing the Aristotelian teleological approach to political praxis by the Heideggerian concepts of existential authenticity and ontological disclosure of Being. ${ }^{301}$

The concept of the public sphere, so central to Arendt's thought, emerges from an elaboration on Aristotle's Politics' differentiation between the political and the economic, the public and the private, the good life and the mere life. Radicalising the divisions elaborated by the Stagyrite Philosopher, Arendt opposes politics with labour and work by presenting the former realm as more existentially revealing.

Beyond their affinity, Aristotle's account of the political is not fully satisfying for the author of The Human Condition. For one thing, Aristotle's hierarchy of human activities places political action as a lower endeavour than the contemplative life. While politics is seen as the architectonic science and an activity linked to human freedom and excellence, ${ }^{302}$ theoretical study, and not action, is considered by Aristotle to be the supreme and most virtuous human enterprise. ${ }^{303}$ The depreciation of the vita activa in favour for the vita contemplativa is a common trend of western philosophy that Arendt resists. In her perspective, the political must be valued in itself, not as stepping stone towards the quasi-divine qualities of the theorein. Because Aristotle's philosophy presents contemplation - a quiet communion with the truth of Being - as the telos of human life, it already upholds a depreciated view of all 'unquiet activity', a position

\footnotetext{
${ }^{301}$ For Arendt, Aristotle's teleology still places praxis into a means-end logic which risked conflating politics with instrumental reason, see Dana Richard Villa, Arendt and Heidegger: The Fate of the Political (Princeton, N.J.: Princeton University Press, 1996).

${ }^{302}$ Aristotle, Nichomachean Ethics, trans. Terence Irwin, Second Edition (Indianapolis: Hackett, 1999), 1-2. ${ }^{303}$ Ibid., 163.
} 
which will only grow with Christianity and Modernity. ${ }^{304}$ Without any doubt, Aristotle counts as one of the most political of all philosophers, yet even he contrasts negatively human activity with the beauty and permanence of the cosmos. ${ }^{305}$ The dignity and worth of the vita activa has been consistently lowered from the trial of Socrates to modern philosophy, all philosophers wanting to partake in the transcendent and perfect quality of the Beyond. Indeed, the lovers of wisdom have tended to prefer the eternity of ideas to the immortality of the heroic deed. ${ }^{306}$ Even thinkers of temporality and critics of the tradition like Nietzsche and Heidegger, Arendt argues, leave the supremacy of the theoretical untouched: "It lies at the very nature of the famous "turning upside down" of philosophic systems of currently accepted values, that is, in the nature of the operation itself, that the conceptual framework is left more or less intact." 307

The philosophers' rejection of political opinion (doxa) in favour of metaphysical knowledge (episteme) is also reflected in all forms of rationalistic organising of society along the line of a unique and atemporal source of order and meaning, be it God, history or the market. The political is thus always threatened, being (rightly) seen as messy, imperfect and all too human. With our longing for perfection, the temptation is always present to escape the political and to replace the role of the political actor by a more stable and unitary subject like the idea of man created in God's image, the concept of humanity fulfilling its destiny, the proletariat, the homo oeconomicus...This temptation to pure ontology has, from Plato's onward, threatened to eat the political from the insides out. As we will explore further in the paragraphs that follow, the political is a highly tragic

\footnotetext{
${ }^{304}$ Hannah Arendt, The Human Condition (Chicago: University of Chicago Press, 1998), 15.

305 Ibid., 14.

${ }^{306}$ Ibid., 19-20.

${ }^{307}$ Ibid., 17.
} 
phenomenon. It can be qualified as tragic because it represents an existential tension seeking its own resolution, an activity directed at its own disappearance. Political space and existence can be symbolised as a tension between difference and communality. The space of freedom it opens and which constitutes the substance of the political is made possible precisely by the impossibility of entirely reconciling difference. Albeit the centrifugal force of government and policing, dissonance and resistance endures in speech and action. As long as politics is political, the direction it gives itself - the common good - never subsumes completely the plurality of opinions and forces. On the other side, this objective, the common good, contains the dream of an apolitical politics, a post-historical management. This tendency of the political to fantasise about its own enclosure is reflected in the phenomenon of bureaucracy, the 'politics of rights' and the enthusiasm of the masses with the replacement of public debate with expertise and market-base efficiency grids.

\section{Consumer society and the return of the homo laborans}

Still, according to Arendt, the greatest threat to the possibility of political existence in our age is the rise of the Social and the victory of the homo laborans over other modes of existence. In the Human Condition, Arendt elaborates on this astonishing observation: labour, which has always been depreciated as meaningless, has now become the primary mode of human activity, at the expense of work and action. The victory of the homo laborans, which in neo-liberalism is personified as a consumer or an 'entrepreneur of one-self', means nothing less than a flattening of meaning, the celebration of an univocal self and the withering of political freedom. Interpreted in light of Arendt's writings, the passage from classical liberalism to neo-liberalism corresponds to the victory of the homo laborans over the homo faber. The archetype of early modern 
modernity, homo faber, is engaged in economic activity as the fabricator of discrete objects. Typical of the age of the industrial and scientific revolutions, the homo faber stands towards his or her work in the split subject/object relation. ${ }^{308}$ His or her creative power, ability and force created this thing which now stands incontestably as distinct and even partly alien. One of the German words used for 'thing' reflects that dialectical relation. In the root of the German noun Gegestand lies the verb gegen: to oppose. Homo faber creates a world of things full of meaning from which people can recognise each other as sharing a common reality and a common experience. The return in force of homo laborans implies a completely different relation to economic activity. In contrast to work, the process of labour might produce 'stuff' but only incidentally, as a residue of the process. The focal point of labour is not its product but the process itself and the logic of growth behind it. In this society of jobholders and consumers Arendt assimilates to the homo laborans, the focus is displaced from the 'what' to the 'how'. As we saw earlier, the importance is placed on the maximising rationality and the market as an ideal matrix of cost and benefits. In this environment where labour and consumption are part of the same cyclical logic, the old subject/object distinction collapses: there is no worker and production, but life consuming life and capital labouring capital.

In this waste society where everything is 'stuff', individuality is an early casualty. Engulfed in the Social, the modern labourer is asked to be one with the economic process, the organisation, the firm, the market. Arendt provides an image of the inauthentic self resembling what her teacher Heidegger denounced as the reign of das Man. ${ }^{309}$ In

\footnotetext{
${ }^{308}$ Ibid., 309.

${ }^{309}$ Das Man is difficult to translate in the English language. More easily understood in French, it means something similar to 'les gens'. For example, the question "Kann Man sagt das?" would be translated by "can someone say that?" This 'someone' is not an active 'We' but a convention uncritically accepted.
} 
Heidegger's words, the inauthentic selves follows thoughtlessly the 'neuter' - the average type or norm (das Man) - instead of being guided by oneself, one's leader or one's people: "we meet them at work, that is, primarily in their Being-in-the-world. [...The Other] 'standing around' is an existential mode of Being - an unconcerned, uncircumspective tarrying alongside everything and nothing [...]." ${ }^{310}$ For both Heidegger and Arendt, it would be inappropriate to speak of freedom in the case of das Man since its condition is simply a tranquilised "letting go". While early liberalism reduced freedom to a negative phenomenon (freedom from), in the most rationalised and radical form of economism it is defined as escaping the realm of human action, as a force passing behind humans' back (the neo-liberal credo: we are free, but there is no alternative...). Clearly, the images used by Arendt to represent the modern homo laborans are better suited for Fordist mass society than neo-liberal government. It is not that the advent of neoliberalism refutes Arendt's condemnation of mass society, but it forces us to be more attentive to the subtler ways normalisation is now fused with individuation. In contemporary neo-liberalism, authentic individuality, the public performance of 'who' one is authentically, remains obliterated. The calls to personalisation and choice are indeed heard everywhere but the individuality it markets is a mere modulation on the universal theme of the market and an internalisation of the economic self. Das Man now uses many masks and brands but it still walks the line.

For this advocate of a greater and more active public space, consumer society represents the monopolization of all open spaces by questions of necessity and prepolitical concerns linked to the biological cycle of the specie. By clearly separating conceptually labour, work, and action, Arendt demonstrates that modern society is

\footnotetext{
${ }^{310}$ Martin Heidegger, Op. Cit., 156.
} 
marked by the victory of the homo laborans over all the other modes of Being. What this radical takeover signifies is the reduction of human activities and endeavours to the category of life processes. In radical economism, or what she calls consumer society, what was specifically human, such as philosophy or politics, becomes meaningless:

What was not needed, not necessitated by life's metabolism with nature, was either superfluous or could be justified only in terms of a peculiarity of human as distinguished from other animal life- so that Milton was considered to have written his Paradise Lost for the same reasons and out of similar urges that compel the silkworm to produce silk. ${ }^{311}$

This condition resembles what Foucault called bio-politics and what Kojève prophesised as the coming of the re-animalised man, humans return to the cyclical pattern of the bios, which the pólis was once able to overcome. In Foucault's constructive view of power, modern government is bio-political insofar as its object is life itself. Naked of the artifices of sovereignty bio-politics manages life itself, whether the objective takes the form of the production of a docile and productive individual body or the growth of populations and the specie. ${ }^{312}$ In the caustic sarcasm of Kojève, the finality of homo laborans and consumer society is the coming to end of history and the re-animalisation of 'Man' where action as negation would disappear and where a fully satisfied homo sapiens sapiens would construct buildings as birds making their nest, playing music as frogs or cicadas and making love as wild beasts do. ${ }^{313}$

This return to 'mere life' is not a homecoming but an alienated way of Being. The modern version of the animal laborans loses itself into the interminable cycles of labour and consumption, incapable of escaping the hustling of modern life and of reaching back

\footnotetext{
${ }^{311}$ Hannah Arendt, Op. Cit., 321.

${ }^{312}$ Hubert L. Dreyfus, Paul Rabinow and Michel Foucault, Beyond Structuralism and Hermeneutics, Second Edition (Chicago: University of Chicago Press, 1983), 134.

${ }^{313}$ Alexandre Kojève, Introduction à la lecture de Hegel (Paris: Gallimard, 1947), 436.
} 
to what constituted authentic human existence and meaning. ${ }^{314}$ In the process of labour, humans do not fabricate a world out of genuinely new things but simply navigate through natural cycles of desire, consumption, stuff, and mere life. In the words of Kateb, labouring masses and consumerist bourgeois, subsumed by natural processes, are seen by Arendt's elitism as human in name only. The homo laborans is incapable of standing apart from his environment and it is quite difficult to assert whether he labours to consume or consumes to labour. ${ }^{315}$ The term 'natural' should not mislead us, Arendt's critique of the homo laborans applies equally to radical economism and the ascendancy of the neo-liberal consumer-entrepreneur we tried to show in the preceding chapters: "nature is in the ascendant as much in the daily life of 'jobholders' in our economy of waste, superfluity, and advance technology as it was in the 'hidden' life lived in premodern times. ${ }^{316}$ Even though neo-liberalism rejects naturalism and considers markets as human artefacts, it presents the same circular logic Arendt perceived in labour. At this level of interpretation, whether one is busy on the land or as a neo-liberal consumer is a detail.

Reading Arendt by placing the accent on her valuation of agonism, a reader can interpret 'labour' as a certain sensibility, a Dasein opposed to the different sensibility necessary for political existence. From this angle, the labourer is not only encountered as a peasant or seen in the private sphere, but can also take the identity of a CEO or come to occupy governmental offices. Proposing a radicalised and anti-essentialist reading of Arendt, Bonnie Honig contrasts in this spirit the univocal self of the homo laborans to the

\footnotetext{
${ }^{314}$ Hannah Arendt, Op. Cit., 137.

${ }^{315}$ George Kateb, Hannah Arendt, Politics, Conscience, Evil (Totowa, New Jersey: Rowman \& Allanheld, 1984), 4.

316 Ibid.
} 
multiple acting self. Arendt, it is true, opposes the biological body that is one (the body which cries 'I desire!' in a most unambiguous manner) and which is essentially identical to all other bodies with the public personae of the political actor. In the public light, the public actor might wear different masks, but these masks are for Arendt more authentically reflexive of his/her identity than the private desires or the inner depth of his/her self. Itself the terrain of agonistic struggles, the multiple self resists the unity imposed by the tyrannical desires of the body and the normalisation of government. The political actor achieves (temporary) identity unity only as a performative production not as a naturalised category or through an ontology of Being. ${ }^{317}$ As with the "We hold" of the Declaration of independence, political subjects are born with their own speech-act. ${ }^{318}$ Unlike the univocal self of radical economism who follows the rule of the market and the identity of the consumer, the political self is always fragmented, torn between public participation and private comfort, debating with himself/herself, contesting opinions and interests, divided by distinct and often clashing faculties (thinking, willing, and judging). ${ }^{319}$ This is why for Arendt the political self never rules or dominates others but only act with others.

Political relations, rooted as we said in isonomia, are too reflexive and agonistic to take such a simple and unidirectional form. Economic motives, in comparison, compel behaviours in a despotic and irresistible manner: the urge for gain comes to the economic self as an incontestable calling, a self-evident direction to follow. ${ }^{320}$ Whatever the ways

\footnotetext{
${ }^{317}$ Bonnie Honig, "Towards an Agonistic Feminism: Hannah Arendt and the Politics of Identity," in Bonnie Honig (ed.), Feminist Interpretations of Hannah Arendt (University Park: The Pennsylvania State University Press, 1995), 137.

${ }^{318} \mathrm{Ibid}$.

${ }^{319}$ Ibid., 141-142.

${ }^{320}$ Ibid., 137.
} 
economism rationalises the commands of the marketplace (utility, profit, performance, etc.), those are not welcoming debate and questioning.

The significance of Arendt's oeuvre however is beyond a lament of modernity and a critique of the Social. Her theorisation of the vita activa also offers us an account of the public realm, political existence and citizenship that reveals positively what radical economism erodes: the integrity of the political and the potential for action. By engaging a dialog between Aristotle and Heidegger, Arendt emphasises the importance of the political as the genuine space of authentic existence, as the activity revealing human identity qua human. The reason human existence is not reducible to mere natural and biological life lies in the fact of human plurality and in our capacity to rise above sheer necessity. These two characteristics are intrinsically linked. Under the light of the public sphere, through action (praxis) and speech (lexis), the fact of human plurality comes to the forefront. The political actor is recognized as a unique being: a person irreducible to a group but who nonetheless exists as part of a body politic (inter hominess esse), as one in a plurality of public selves.

In the public forum, a diversity of people confront their differences in defining a common good, recognizing each other as a pluralistic 'We' and projecting themselves in the future. Confronted by diverging opinions and finding solidarities and common ground they did not expect, citizens experience the political realm as division and integration. ${ }^{321}$ A common ground is sometimes found, but the synthesis is always opened to contestation, never resting. Pécharman words are aptly chosen to describe this phenomenon: "Le politique - ce qui concerne les citoyens dans leur totalité - est un

\footnotetext{
${ }^{321}$ Like in the first chapter, we are here influenced by Duverger and his imagery of politics as Janus-faced. See Maurice Duverger, Op. Cit., 22.
} 
universel qui n'est connu de tous que parce que chacun l'éprouve comme tel, en tant qu'objet commun manifesté et visé par des discours antithétique." ${ }^{\text {222 }}$ This public space opened in politics stresses commonality but is engaged through dissonance; conceptions of the common good always remain abstractions and our opinions of it should therefore not be traded for dogmas. Arendt also makes this point when she teaches that "men organize themselves politically according to certain essential commonalities formed within or highlighted from an absolute chaos of differences." 323 The political, thus conceived as a space of agonism and commonality, lies not, as Aristotle would have it, 'in Man' (as practical reason), but between humans as a relationship, an existential potentiality, a mode of Being-with-others. ${ }^{324}$ For the Ancient Greeks, the economic is simply incapable of reflecting in this way the fact of plurality. In this regard, neoliberalism is original since it claims to complete that integrating function. Departing from the naturalistic approach of classical liberalism which saw everything from the macro level, neo-liberalism personalises the economic function of the worker and the consumer. The logic at the basis of economic activity moves from belonging to self identity. This change is evident in the so-called new management. The individual is not defined by his or her corresponding class or station but by his/her lifestyle and individual potential; in the office he/she is called a partner, an associate; elsewhere he/she is taught to be flexible and creative and to follow the ideal of the autonomous worker. Supposedly, the multiple markets of life will modulate differences. Since this so-called difference and individuality is only an alternate version of the same (a certain position in relation to a market and a

\footnotetext{
${ }^{322}$ The political - that which concern citizens in their totality - is a universal that is known by everybody only experience it as a common object each because recognise manifested and directed at by antithetical discourses. [my translation] Martine Pécharman, "L'idée du politique," in Denis Kambouchner (ed.), $O p$. Cit., 93.

${ }^{323}$ Hannah Arendt, The Promise of Politics (Schocken Books: New York, 2005), 93.

${ }^{324}$ Ibid.
} 
marketing of one-self), Arendt is right to reject it as more cosmetic than authentic. Still, this government through choices and individuation pretends, as we highlighted in the preceding chapter, to be capable of 'managing' people without the aid of political action and speech. It effectively offers a model of order predicated on the idea of self-pacifying passions, where differences are first inoculated as market inputs. Presenting the economic as the genuine realm of differences and innovations, radical economistic movements then reject political conciliation of human plurality as superfluous.

Seen in this spatial dimension, the political also precedes classification of regimes, including democracy. Contrary to common opinion, the concept at the foundation of the political experience is not the rule of the people, which as we know from Toqueville can fall into mere conformism or soft despotism, but this condition the Greeks called isonomia, equality in speech. Literally translated by the potentially misleading term 'freedom of speech', isonomia originally meant that those who engage in political activity [whether everybody, an aristocracy, a limited citizenry or an oligarchy] do so as equals. ${ }^{325}$ Contrary to the definition of isonomy Hayek has used to support his critique of democracy, this old concept does not mean that the authority of the law is prior to the power of the people but rather that "all have the same claim to political activity." 326 This political recognition beyond status and family breaks with the traditional and tribal bounds of the community. Blood and rituals are displaced by reasoned speech (logos) as the unity of the pólis. The fact that the Ancient Greek word for citizenship, the citizen body and the constitution of the pólis is the same (politeia) speaks volume on the very political nature of the Greek institutions. It reflects "the unity of the citizens, not only the

\footnotetext{
${ }^{325}$ Martine Pécharman, "L'idée du politique," in Denis Kambouchner (ed.), Op. Cit., 94.

${ }^{326}$ Hannah Arendt, The Promise of Politics (Schocken Books: New York, 2005), 117.
} 
sum of the individuals, but the living body composed of rulers and ruled, and the political life that was the very life and being of the citizens." ${ }^{327}$ The separation civil society/state that is predicated in the modern conception of social citizenship was alien to the Greek pólis. Beyond a mere juridical unity, the concept of citizens as politeia implied the existence of a healthy political sphere: the citizens were the pólis, the pólis was the citizens. With the reforms of Cleisthenes, the family and the tribes lose some power and the city-state is re-articulated around citizenship and the immanent dialectics of individual voices and the public (koinon). ${ }^{328}$ Before Cleisthenes, other statesmen tried to instill in Athens a national identity, like Solon, Athens' first great lawmaker when he forbade neutrality in trials. However, in 508 B.C, Cleisthenes goes further with his reform and, as Herodotus immortalised, "took the demos into partnership". ${ }^{329}$ To break the bounds of private interests and tribal ties that divide the city in opposing clans and place kinship before citizenship, Cleisthenes abolishes the old ten Ionic tribes and creates ten new ones. ${ }^{330}$ As always in ancient times, the political act of foundation is imbued with religious undertones. Cleisthenes is keen to associate each of these new tribes with the worship of eponymous heroes drawn from Attic legends. In so doing, religion is displaced from a source of division to symbols attesting to the sacred union of Attica and the necessity of a common polity. ${ }^{331}$

In the political sphere, the link between plurality and unity can be forged in the form of the active citizen. Through citizenship, the resolution between what is my voice and what is the common good is idealised as an internalised sentiment of commonality in

\footnotetext{
327 Victor Ehrenberg, The Greek State (New York: W. W. Norton \& Company, 1960), 39.

328 Ibid., 31.

${ }^{329}$ A. H. J. Greenidge, A Handbook of Greek Constitutional History (London: Macmillan and Co., 1911), 157

${ }^{330}$ Ibid.

${ }^{331}$ Ibid.
} 
difference, from a fragile sense of belonging to a fusional Rousseauan General Will. In economic processes, by contrast, the integration is enacted through the market. The homo oeconomicus signifies his/her needs and what he/she has to offer but remains an essentially private being; the resolution of the tension between ' $\mathrm{I}$ ' and 'We' does not pass through his/her identity but through the equilibrium function of the market.

But lest we be complete romantics, we need to acknowledge that the political space is not only positive. The determination of a 'We', a shared public space and a common good leaves in its shadow a 'They', a rejected ethos, an 'other'. From its beginnings, citizenship is discussed in terms of exclusion: that of the poor, the women, the slaves, the barbarians. But this process of political 'othering' does not mean that political existence is more exclusionary than other modes of Being, much to the contrary. In the political sphere, the limits of the political community are themselves political questions. Questions like "Who are we?", "what is it to be a citizen?" and "who is/are to rule?" are not supposed, in a polity, to be left to tradition or sacred books alone. The German jurist Carl Schmitt was right to emphasise the agonistic edge of political identity. ${ }^{332}$ The political is unthinkable in the absence of the categories of the 'us' and the 'they', of the distinction between friends and enemies. The idea of the common good, of a human end of all ends, entails in itself a negation. Since the political domain claims to reflect a community of values and give to it direction and form, it necessarily engages in a dialectical or antagonist relation with an 'other'. Somewhere, somehow, a way of Beingin-the-world is partly or completely rejected. In this sense, the government of a homogeneous and universal state could no longer be called political. However his insight

\footnotetext{
${ }^{332}$ Carl Schmitt, The Concept of the Political, trans. George Schwab (Chicago: The University of Chicago Press, 1996).
} 
into the dark side of the pólis, Schmitt confuses the a priori conditions with the substance of political existence. By emphasising enmity and opposition, Schmitt does not do justice to the dialectical movement of politics, there is as much philia as agōn in the determination of the common good.

While affirming one self implies negating an 'other', the human longing behind political activity is not only negative. Central to the public space of appearance that is the political sphere is the human desire to be remembered beyond death. The active citizenry idealised by Arendt is comprised of lovers of excellence who, like Achilles, seek to gain some of the immortality (permanence) that is normally reserved to biological species or pagan gods. ${ }^{333}$ Public space is conducive to such public engagements and agōn. Dossa analyses convincingly Arendt's thought when he explains that behind the human striving to do well, excel and gain public glory lies an innate repugnance to futility:

For Arendt it is their repugnance to futility which prompts men to do well and that doing well is a public claim, not a private one. [...] Doing well is to excel in the public arena, in the esteem of fellow men, preferably one's peers. No one can be said to have done well if he does not venture into and elicit the approval of the public in the public realm. Hence doing well is the same as actualizing the capacity for freedom and action inherent in men. ${ }^{334}$

Wishing to escape futility, the political being does not wish to be forgotten as a simple reflection of the group or mass but, on the contrary, longs to be recognised and reckoned as a meritorious and active member of a political community of actors. This citizen, aware of its existence and finitude, cannot be content with the impersonal permanence accorded by the cycle of reproduction and evolution's aggrandisement of the species and life in general. For Arendt, it is our mortal nature which entices us to strive beyond the

\footnotetext{
${ }^{333}$ Hannah Arendt, The Human Condition (Chicago: University of Chicago Press, 1998), 18, 25.

${ }^{334}$ Shiraz Dossa, The Public Realm and the Public Self: The Political Theory of Hannah Arendt (Waterloo, Ont., Canada: Wilfrid Laurier University Press, 1989), 86.
} 
private satisfactions of the household and the cycles of labour and consumption and to project ourselves in the future through an engagement in the "good life" and freedom of the pólis. ${ }^{335}$ We put ourselves under public light and enter the realm of action because the pólis is capable of offering remembrance and thus to preserve for some time the uniqueness of our individuality.

In this interplay of act and speech, of contest and recognition, public space makes visible the individuality of the actor. Living politically, one can reveal, through principled positions and acts, his/her distinctiveness and thereby live a more authentic life. Arendt's phenomenological theory defines the political as the human capacity to act, whether with or against others. According to her theory, we come into the world not primarily through the negation of an 'other' (although this is an inevitable dimension of identity formation) but through the affirmation of one's uniqueness through speech and deeds. For her, the capacity to take an initiative and put an original movement into motion (to create a sui generis reality), what she refers to as natality, represents the true miracle of human existence. ${ }^{336}$ Speech and action, when deployed in the public realm, reveal our distinctiveness - this "paradoxical plurality of unique beings" 337 - and present us with the incredible opportunity to give birth and be born again in the act. While our physical and bodily uniqueness is a given, our coming to appearance into the human world as unique actors and the distinctiveness of the spiritual dimension of our identity only unfold through free acts and speeches. These two primordial human activities uncover the identity of the human actor beyond its attributes, qualities or its function in the world. In Arendt's republican ideal, the proper answer to the liberal and more generally modern

\footnotetext{
335 Hannah Arendt, Op. Cit., 18-19.

${ }^{336}$ Ibid., 178.

${ }^{337}$ Ibid., 176.
} 
hyper-individualism is not to be found in the nation or the ethnic group, but in this inbetween space where citizens engage dialectically with their political community:

In acting and speaking, men show who they are, reveal actively their unique personal identities and thus make their appearance in the human world, while their physical identities appear without any activity of their own in the unique shape of the body and sound of the voice. This disclosure of "who" in contradiction to "what" somebody is - his qualities, gifts, talents, and shortcomings, which we may display or hid - is implicit in everything somebody says and does. ${ }^{338}$

Because of their revealing power, public speech and action stand in opposition with the interchangeable self of mass society and the neo-liberal atomised-individual.

\section{The political against policing}

Since it sheds light on the authentic personae of public actors, the political is also the stage of resistance to governmental subjectivities, discipline and policing. Because of the common association between politics and the state, people quickly equate political activity with the elite, the established order, laws. In Canada, the image of Parliament Hill typically comes to mind. But since the political occurs in a metaxy (a line of tension between individuality and universality, difference and equality), it also possesses a rebellious dimension. Arendt's account of politics as authentic action and speech illuminates the amiable side of the political, but it does not account for its more radical side. On this question, we can turn for guidance to the French philosopher Jacques Rancière who lays open the internal tension between the political and policing. To be political, Rancière reminds us, is to stand in between individuality and universality, solidarity and heteronomy. Here again, the distinction between a political actor and the market agent is evident. To stand as a political actor is to refuse complete policing and to adopt the often uncomfortable position of an 'in-between', someone that does not accept

${ }^{338}$ Ibid., 179. 
uncritically the conventions of the land, common-sensical definitions or the essentialism of identities. Rancière gives us the example of a French woman who asks herself if a Française is included in the generic term Français used in laws and statutes. We could also give in example the figure of Socrates whose form of citizenship involved questioning conventions and acting like a political gadfly. In this critical zone where the political confronts police and government, 'equality in plurality' is made possible. To live politically, in this sense, is also to resist complete policing in the determination of one's life; it is the immigrant who refuses deportation by reclaiming the name American; it is the woman who questions her inclusion in the noun homme of the Déclaration universelle des droits de l'homme; the worker who calls himself a proletarian; the student activist who refuses to limit his/her action to so-called 'student politics' and who discovers, through action and solidarities, what was previously unthought-of, or see those who were previously unseen, that he is also a citizen. Clearly, there cannot be political existence without some form of order, and the political is always concerned with its preservation, but it also refuses, resists, rebels against the categories or subjectivities delimited by the powers that be. As Arendt says, the political is concerned more with the question 'who are you' than with the paradigmatically social preoccupation 'what are you'. To live a political life is therefore not merely to take impersonal positions on some issues after reasoned deliberations but to 'take a stand', and often a polemic one. This is why the Greeks understood entering political activity as an adventurous and risky move; to enter the political realm was to abandon the secure realm of the household where one exercised dominion and where one's identity was left unquestioned. To be recognised as first among equals, in this space of appearance and contest where excellence was so much 
prized, one had to risk his life in the public. ${ }^{339}$ There, in the eyes of his peers, the citizen could not claim the sort of private dominion imposed on women, children and slaves, unless he became a tyrant and forbade access to the political realm. To claim greatness, one could neither rely solely on family connections or personal fortune.

To many readers, this conception of public space will seem very far from their reality and appear as an idealisation of the past. But Arendt's idealization of the Greek pólis and the political is not without value. Without falling into complete utopia, Arendt's concepts of public space and action help us to recover, through strong contrasts and imageries, a certain possibility of Being which might not appear possible at first sight. Conscious of the difference between an ontological and existential ideal, Hansen rightly distinguishes Arent's idealisation of the Greek pólis from pure idealism:

If Arendt is utopian she is a utopian of the 'here and now': If there is an utopianism to her thought, it is not a mystical yearning for distant shores. It is what I would call an utopianism of the 'here and now' : an immanent utopianism rooted in the articulation of currently existing human capacities and competencies as they are manifested in actually existing societies, even in a distorted form. ${ }^{340}$

Hannah Arendt's return to the Greek ideal of heroic politics also has the virtue of providing an alternative version of individualism. Against the backdrop of mass society's atomised and thoughtless individualism, Arendt projects the ideal of a individualism finding its uniqueness and authenticity in public engagement rather than in the futility of consumerism or in the vacuous search for the depth of the inner self. As Villa explains, Arendt's modernism, her understanding of the importance of what Taylor has called the 'politics of authenticity' and which others have encountered as 'identity politics' is in her

\footnotetext{
${ }^{339}$ Hannah Arendt, The Promise of Politics (Schocken Books: New York, 2005), 122.

${ }^{340}$ Phillip Hansen, Hannah Arendt, Politics, History and Citizenship (Standford: Standford University Press, 1993), 8.
} 
political theory conjugated with an ancient wisdom associating the care of the self with the concern for others. According to her, real individuality shines not in the private but in the eyes of others. This form of authentic individuality however, is not cheaply acquired. It cannot be bought or marketed, but requires an ongoing engagement: "It is one thing to presume one's uniqueness (as we moderns are wont to do), quite another to demonstrate it in a worldly and disciplined way. This is achieved through the opinions and consistent perspective an individual communicates to his/her fellow citizens "in the bright light of the public sphere." ${ }^{341}$ Unlike Aristotle, Machiavelli, Rousseau and modern communitarians, Arendt does not value the public sphere and citizenry because they are essential conditions for virtue, but on their own, as some of the primary ways to be human, opening a realm of freedom where the world we live in is illuminated, not dimmed out or flattened by the fusion of our various perspectives.

Many scholars, even sympathetic ones, have criticised Arendt's rigid dichotomy of the political and social sphere and the lack of nuance in her rejection of 'social politics'. Indeed, one can rightly wonder how Arendt can, on the one side, mark the private as a pre-condition for the public and, on the other side, reject with an aristocratic attitude its politicisation. While the private is not the public, the limit of the political with the private must be politicised. The question is of high importance since it determines who has access to political life and on what grounds. In our opinion, Arendt is contradicting herself on this point. One the one hand, it is true, a citizen is simply someone who lives as one and, in this sense, all those lacking the leisure to access the public sphere are not, as a matter of fact, political beings. On the other hand, Arendt herself grounds the existential possibility of the political in the human condition, in the

${ }^{341}$ Dana Richard Villa, Socratic Citizenship (Princeton: Princeton University Press, 2001), 251. 
human potential to make anew, to act in the fullest sense of the word. Seen from this second perspective, political existence is a universal potentiality and citizenship cannot be denied on the ascriptive basis of class, gender or race. Moreover, while social conditions enabling people to access the public sphere as equals might not be political as such, in the sense of a participation in the common good and the realm of public speech and action, they represent a sine qua non condition of the emergence of the political sphere and for a citizenry that is not simply the reflection of class or private interests. What is at stake is the vitality and access of the koinon, the public, which precedes the appearance of the political. Before being enfranchised, made citizens, the demos must first be invited to the symposium. ${ }^{342}$ In order to develop educated opinions rather than mere prejudices and in the spirit of isonomia, citizens must first be freed from necessity, carved a space of individuality allowing them to differ of opinions from the mass, and must be educated through a multiplicity of social institutions such as the widespread participation in civil society Toqueville notices in Revolutionary America. In sum, as long as they are thought of as means and not as ends, social questions do not have to impede political existence and can even encourage it. We do not have to resist radical economism in a negative or reactionary spirit, rejecting all that is economic as deserving of contempt. Our hope for the political should not be transformed into a renewed hatred for the body, the old metaphysical resentment against the world of 'mere appearance'. Rejecting the claims of economism to represent the totality of Being and to take the role of the new master science, we can nevertheless recognise the importance of the economic for sustaining material needs and to make possible the formation of a public realm. The political must

\footnotetext{
${ }^{342}$ Pauline Schmitt-Pantel, "Collective Activities and the Political in the Greek City," in Oswyn Murray and Simon Price (eds.), Op. Cit., 201.
} 
not become a new name for this metaphysical ideal that philosophers and believers have looked for in the heavens. If the pólis is the citizens that compose it, these citizens are not incorporeal gods. The political agora must be distinguished from the marketplace, but we must not fool ourselves. The public sphere remains a space where living humans meet; humans with bodies that work, eat, sleep, love and die. To paraphrase Virginia Woolf, before entering the public sphere, one first needs a room of one's own, the social conditions rendering materially possible a public life and a private space which can protect the citizen from the tyranny of the 'They'. ${ }^{343}$

Before concluding this final chapter there is one important question that we need to address, even if only briefly. The question presents itself as such: how is it that everything is today presented as political if it is true that the political retreats at the profit of the economic? We cannot deny that all topics are now considered opened to political debate and criticism, that people even talk of 'food politics' for instance. In reality, the same phenomenon of radical economism that eclipses the possibility of the political existence $^{344}$ is associated with the process of democratisation that clears the way for the public participation of everybody and the questioning of all topics. Although the word power and government should in our opinion be preferred to avoid misconception, one could say that everything is now politicised if by that statement this person merely wants to signify that everything is imbued with power and contestable, or on a more negative level, that everything is governmentalised. In this sense, careless assertions of the fact that 'everything is political' point both to the loss of distinction of the political sphere and highlight a democratisation of critique, the fact that no human reality escapes critical

\footnotetext{
${ }^{343}$ Virginia Woolf, A Room of One's Own (Peterborough: Broadview Press, 2001).

${ }^{344}$ Understood in the Arendtian definition of the political as the realm of action, active citizenship, public space and the common good.
} 
discourse and that power relations, wherever they are, can be asked to be justified and explained. ${ }^{345}$ This reflection can lead us to a second question: would a renewed political sphere be better sustained by returning to a strict delimitation of the public by isolating the social from the political or would it be best to encourage a form of radical citizenship which would, in an Arendtian spirit, involve debating and acting in concert on all questions concerning the common good and the community's distinct mode of Being-inthe-world? Arendt was tempted to define rigidly the domain of political debate because she believed including social issues would corrupt the exercise. We are sympathetic to her motivations and also wish to bring economic and social questions back to their proper place. However, excluding the economic from the scope of political deliberation might prove it-self not only impossible but unwise. To continue with the imagery of realms or spheres of existence, should not the master science be allowed to rule over its main frontier? Should it not be allowed to deliberate and take action on what we previously referred as the koinon, the ensemble of institutions of sharing and equality which must exist for isonomia and the public sphere to emerge? If political existence is such a fundamental dimension to being human, perhaps it is legitimate to encourage the conditions fostering such a life.

\footnotetext{
${ }^{345}$ Of course the economic sphere has also been affected by the enlargement of the field of critique. We must not forget that the word consumerism does not only mean civic apathy and the erosion of a consciousness of the common good but is also used to define a social movement. A new form of activism appearing in the $19^{\text {th }}$ century and gaining momentum in the $20^{\text {th }}$, consumerism forced big businesses to take into account the health and interests of its ordinary consumers and occupied a discursive field - the economy - hitherto reserved to the elite. In so doing, consumerism manifested the counter-movement typical of economism and all totalising movement. If we can legitimately talk of a colonisation, a retreat or an erosion of the political we must be aware that there is also the return of the pendulum. While we behave increasingly as consumers and entrepreneurs, we also introduce ethical questions and concerns to our consumer choices. See in particular David Horowitz, The Morality of Spending: Attitudes toward the Consumer Society in America, 1875-1940 (Baltimore: The John Hopkins University Press, 1985) and Robert N. Mayer, The Consumer Movement: Guardians of the Market-Place (Boston: Twayne Publishers, 1989).
} 


\section{Conclusion}

Throughout this thesis, we demonstrated that neo-liberalism is a form of radical economism, a movement expanding the reach of the economic realm in a rationalistic and even totalising manner, and therefore represents a retreat of the political. The transformation in the understanding of the boundary and hierarchy separating the economic from the political realm - leading to the ultimate amalgamation of the two in neo-liberalism - is striking. The word radical does not appear exaggerated to qualify the departure of neo-liberalism from the previous conceptions of oikonomia, which designated the private domain concerned with the fulfilment of the community material needs, and the classical liberal understanding of the market as the natural force leading to the accumulation of wealth. As defined in the writings of the Chicago School of Economics, economic activity encompasses a far wider range of activities than what is commonly called the 'economy'. A maximising rationality, neo-liberalism conceives of the economic sphere as pervading everything, in the form of the market, and ascribes to it the capacity to provide us not only with subsistence and material growth, but with a basis for order and meaning. In sum, radical economism claims for economics the role of architectonic science once reserved to politics.

In the opening chapter, we gave a sketch of the relation between the economic and political spheres of existence as conceived in the European Antiquity and Middle Ages. The purpose of this important yet brief overview was to highlight the contingent character of economism and to make evident that the present primacy of the economic realm was not always accepted or approached as a given. By contrasting contemporary reality with such a different standpoint, one can see how classical liberalism, even though more moderate and balanced than neo-liberalism, still represents a clear advance of economism. 
Secondly, through a short genealogy of the birth of political economy, we showed how economism takes root in early modernity and is not coextensive with neo-liberalism. This chapter allowed us to distinguish the rise of economism from its most radical manifestation, neo-liberalism, and provided a second point of comparison, strengthening our analysis. Interpreting Adam Smith as a moderate thinker seeking to preserve the ideals of Enlightenment against its own rationalistic delusions, the positions of the founder of modern economics are much more balanced and nuanced than the ideology and program advanced by the Chicago School of Economics. Contrary to the mistaken but widespread opinion on Smith and his famous 'invisible hand', a close reading of his corpus makes clear that while this author ascribed an important role to the economic as a part of the pre-rational and natural order, he upheld the specifically human and stoicallyoriented ethical life as superior. A critic of Bernard Mandeville, Smith conceived of civil society as a multilayered and rich fabric of which the economic is only one dimension.

The third chapter represents a turning point in our analysis. Dedicated to neoliberal thought, this section focuses on the Austrian School of economics and the Chicago School of Economics. The first scholar analysed in this section is a major theoretical figure of neo-liberalism, the Austrian economist and philosopher of science Friedrich von Hayek. Although Hayek philosophical subtleties are rapidly tossed aside by its American counterparts, the Chicago School of Economics inherits his doctrine of the market, which conceives it as a spontaneous order superior in all points to human planning. Devoid of Hayek anti-rationalism however, American neo-liberalism brings economism to its most extreme form by generalising market rationality to all actors and institutions and applying its logic to things so different as education, crime and love. In sum, this chapter demonstrated the radical dimension of neo-liberal economism. Using the writings of the 
Chicago School of Economics and the different applications of its doctrine by new institutionalist theories, we demonstrated the tendency of neo-liberalism to expend the reach of the economic in a rationalistic, totalising and imperialistic fashion.

In the fourth and fifth chapters of this thesis we further analysed neo-liberalism from the perspectives of Foucauldian sociology and Arendtian philosophy in order to understand the significance of this movement in terms of both power and meaning. Approached as an original form of governmentality, neo-liberalism was shown to represent the instrumentalisation of market rationality and its projection as an ideal selfgenerating order. As it was made clear, symbols of sovereignty and disciplinary techniques remained active, thereby creating a form of subjectivity based on interest and choice that is nevertheless normalised, well-tempered and docile. Although interesting on its own terms, the Foucauldian analysis of neo-liberalism as an individualised mode of power equally sheds light on the dethronement of the political as the realm of order, stability, freedom and difference. Understanding economics as a science of order, radical economism claims that the imperfect activity of politics is at best superfluous and proposes in its stead the use of market mechanisms in the determination of governmental policies and programs. The sociological analysis of neo-liberal governmentality is hence a significant contribution to the understanding of radical economism. The primacy of the economic is predicated of this claim to provide not only wealth but also identity, freedom of choice and a non-coercive structure of order. Turning then to Hannah Arendt, we discussed the integrity and significance of political existence. In so doing, we brought back to the fore this mode of Being-with-others that economic rationality ignores. While there is power and government in neo-liberal economism, the experience of the political 
and active citizenship recedes as does the possibility for authentic difference, action, and human plurality.

Considering the broadness of our thesis, it should not be read as a definitive account on the subject. Clearly, each period studied is so rich and complex that it would have warranted a thesis of its own. We decided to privilege such a broad overview because we thought it better suited to the large subject that is the rise of economism. In our opinion, discussing such a wide spectrum of historical periods and ideas, ranging from Archaic Greece to contemporary society and from Plato to Milton Friedman, is at the same time the source of this thesis' potential shortcomings and what makes it interesting. Another limitation of this thesis lies in the impossibility of reconciling completely Foucault and Arendt. On one side, Foucault's post-structuralism refuses to engage such categories as the political, the economic, the human or existence; such allencompassing categories are precisely what Foucault tries to problematise by showing how knowledge is intertwined with power. On the other side, approaching such categories as spaces or modes of existence, Arendt's phenomenology awakens us to the distinction between political activity and neo-liberal government and the flattening of meaning represented by radical economism. The ideas advanced by these two intellectuals cannot be completely harmonised and, in the end, it can be asked why they should be. The persisting difference between these interpretations should not lead us to sterile debates on who's approach on economism is right and who's is wrong. Foucault and Arendt write from different traditions, with different languages; we can either choose a camp or enrich our understanding of both teachings, we chose the second option.

The limitations of this thesis should be taken as opportunities for further research and study. One concept that warrants further attention is the koinon, this common domain 
of peers. We believe political theory can learn from classicists like Pauline Schmitt-Pantel who describe how this space of equality and shared experience appeared in Archaic Greece with the citizens' participation in private yet collective activities like hunts, banquets and sacrifices. These collective practices created the common space necessary for the later emergence of political institutions and isonomia. In the language of SchmittPantel, "to have a share in citizenship is to have a share in a banquet." 346 Further study of this liminal space could improve our understanding of the integration of the private and the public spheres and allow a more relational and less essentialist conception of the political. Enriched by the concept of the koinon, a phenomenology of the political sphere could preserve the integrity and distinctive reality of this realm without conceptualising the boundary of these domains as fixed and sealed. We think this conception of the political as a way of 'Being-with-others' provides more insights than does its uncritical adoption as an essentialised category.

It is our contention that the question of the political has become more important than ever. Even thought we did not touch this subject upfront, writing this thesis has lead us to reflect on the possibility of a different form of socialism where the primacy of the political is affirmed and active citizenship is fostered. In essence, we came to agree with Arendt that the substance of politics is freedom and that political existence is justified on its own. Considering radical economism as one of the most serious threats to human action, we believe it would be time for the emergence of a political and agonistic socialism, one that does not take its answers from an all encompassing ideology (or waits for a new little red book) and that is not paralysed by nostalgia or resentment. We are all

\footnotetext{
${ }^{346}$ Pauline Schmitt-Pantel, "Collective Activities and the Political in the Greek City," in Oswyn Murray and Simon Price (eds.), Op. Cit., 200-201.
} 
too aware that socialist movements have generally been predicated on an economistic conception of the revolutionary subject and have valued the political only instrumentally as a mean to economic socialisation. We believe this hierarchy can and must be inverted, and the political taken seriously.

On a more general level, the urgency of the question of the political is closely related to the modern condition of cultural nihilism. We are living in a paradoxical epoch. In this age marked, as we saw, by the disappearance of the distinction between life and mere-life, action and behaviour, government and politics, the possibility of political existence seems closed from the onset. On the other hand, the modern predicament we live in, namely the collapse of transcendent sources of order, makes being political more necessary then ever. With the Death of God, the guiding light must now be our own, and we can either lose ourselves into the meaninglessness and existential void of mass society or have the courage of living political lives. Certainly, political existence is not the panacea to all our problems and misgivings; in fact, to be political is also to carry the burden of the past and to see the limits imposed by the present. Yet deliberations and debates over the common good or the good life will simply not take place lest we distinguish politics from marketplace and citizens from consumers. In this light, it is not sufficient to critique neo-liberalism as an ideology advocating ideas and policies we reject. The generalisation and prioritisation of the market advanced by neo-liberalism must be unmasked and decried for what it is: a radically anti-political movement that closes the public stage from political ideals, discourses and actions. Resisting this flattening of human existence, we do not look at the past in nostalgia or for a return to a paradise lost, but to remind us that things can change and to reverse the burden of proof of those who preach the primacy of the economic. 


\section{Bibliography}

Ackerman, Frank and others (eds.). Human Well-Being and Economic Goals. Washington: Island Press, 1997.

Agamben, Giorgio. Homo Sacer: Sovereign Power and Bare Life. Stanford, California: Stanford University Press, 1998.

Alvey, James E. "Moral education as a mean to human perfection and social order: Adam Smith's view of education in commercial society." History of the Human Sciences 14, No. 2 (2001): 1-18.

Aquinas, St. Thomas. Summa Theologiae. New York: McGraw-Hill, 1974.

Arendt, Hannah. La crise de la culture. Paris: Gallimard, 1972.

Arendt, Hannah. The Human Condition. Chicago: University of Chicago Press, 1998.

Arendt, Hannah. The Promise of Politics. Schocken Books: New York, 2005.

Aristotle. Nichomachean Ethics. Indianapolis: Hackett, 1999.

Aristotle. The Politics. Chicago: University of Chicago Press, 1985.

Ashley, Richard K. "Three Modes of Economism." International Studies Quarterly 27, No. 4 (December 1983): 463-496.

Bacon, Francis. The New Organon. Cambridge: Cambridge University Press, 2000.

Barry, Andrew and others (eds.) Foucault and Political Reason: Liberalism, Neoliberalism and Rationalities of Government. Chicago: University of Chicago Press, 1996.

Becker, Gary S. The Economic Approach to Human Behavior. Chicago: The University of Chicago Press, 1976.

Becker, Gary S. Theory of Political Behavior. Chicago: University of Chicago Press, 1981.

Bonnafous-Boucher, Maria. Un Libéralisme sans Liberté, du terme «Libéralisme» dans la pensée de Michel Foucault. Paris: L'Harmanttan, 2001. 
Buchanan, M. James and Tullock, Gordon. The Calculus of Consent, Logical Foundations of Consitutional Democracy. Indianapolis: Liberty Funds, 2004.

Burchell, Graham, Gordon, Colin and Miller, Peter (eds.). The Foucault Effect: Studies in Governmentality: with two lectures by and an interview with Michel Foucault. Chicago, University of Chicago Press, 1991.

Brennan, Goeffrey and Buchanan M. The Reason of Rules, Constitutional Political Economy. Cambridge: Cambridge University Press, 1985.

Brown, Wendy. "Neo-liberalism and the End Liberal Democracy." Theory and Events 7, No. 1 (2003): 1-43.

Buchanan, James M. and Tullock, Gordon. The Calculus of Consent, Logical Foundations of Consitutional Democracy. Indianapolis: Liberty Funds, 2004.

Cassirer, Ernst and Hendel, C. W. The Myth of the State. New Haven: Yale University Press, 1974.

Cicero, Marcus Tullius. On the Commonwealth. Trans. George Holland Sabine and Stanley Barney Smith. Indianapolis: The Bobbs-Merrill Company, 1929.

Conrad, A. H. Meyer, J. R. "The Economics of Slavery in the Antebellum South." Journal of Political Economy 66 (1958): 95-130.

Constant, Benjamin. Political Writtings. Cambridge: Cambridge University Press, 1988.

Crick, Bernard. In Defense of Politics. Fourth Edition. Chicago: The University of Chicago Press, 1992.

Cropsey, Joseph. Polity and Economy. The Hague: Martinus Nijhoff, 1957.

Dean, Mitchell. "Liberal government and authoritarianism." Economy and Society 31, No. 1 (February 2002): 37-61.

De Coulanges, Fustel. La Cité Antique, étude sur le culte, le droit, les institutions de la Grèce et de Rome, Vingtième édition. Paris: Hachette, 1908.

Denis, Andy. "Was Adam Smith an Individualist?" History of the Human Sciences 12, No. 3 (August 1999): 71-86.

De Romans, Humbert. “On Markets \& Fairs (c. 1270).” Internet Medieval Sourcebook (Fordham University), http://www.fordham.edu/halsall/source/1270romans.htm (accessed May 16, 2006). 
De Roover, R.A. San Bernardino of Siena and Sant' Antonino of Florence; the two great economic thinkers of the Middle Ages. Boston: Baker Library Harvard Graduate School of Business Administration, 1967.

Dossa, Shiraz. The Public Realm and the Public Self : The Political Theory of Hannah Arendt. Waterloo, Ontario: Wilfrid Laurier University Press, 1989.

Dostaler, Gilles and Ethier, Diane (eds.). Friedrich Hayek, philosophie, économie et politique. Montreal: ACFAS, 1988.

Duncan, Colin M. and Tandy, David W. (eds.). From Political Economy to Anthropology, Situating Economic Life in Past Societies. Montréal: Black Rose Books, 1994.

Duverger, Maurice. Introduction à la politique. Paris: Gallimard, 1964.

Dreyfus, Hubert L., Rabinow, Paul and Foucault, Michel. Beyond Structuralism and Hermeneutics, Second Edition. Chicago: University of Chicago Press, 1983.

Ehrenberg, Victor. The Greek State. New York: W. W. Norton \& Company, 1960.

Finley, M. I. The Ancient Economy. Berkeley, University of California Press, 1973.

Fitzgibbons, Athol. Adam Smith's System of Liberty, Wealth, and Virtue. Oxford: Clarendon Press, 1995.

Fleischacker, Samuel. On Adam Smith's wealth of Nations. Princeton: Princeton University Press, 2004.

Foucault, Michel. Dits et écrits, Vol. IV 1980-1988. Paris: Gallimard, 1994.

Foucault, Michel and others, Naissance de la biopolitique : cours au Collège de France (1978-1979). Paris: Gallimard-Seuil, 2004.

Friedman, Milton. Capitalism and Freedom. Chicago: The University of Chicago Press, 2002.

Friedman, Milton and Friedman, Rose. Free to Choose, A Personal Statement. New York: Avon Books, 1979.

Geertz, Clifford. "Culture and Social Change: The Indonesian Case." Man, New Series 19, No. 4 (December 1984): 511-532.

George, Susan. "A Short History of Neoliberalism." Conference on Economic Sovereignty in a Globalising World (March 1999), in Global Policy Forum, http://globalpolicy .org/globaliz/econ/histneol.htm (accessed May 20, 2006). 
Giddens, Anthony. Modernity and Self-Identity: Self and Society in the Late Modern Age. Cambridge: Polity Press, 1991.

Goldie, Mark and Wokler, Robert (eds.). The Cambridge History of Eighteenth-Century Political Thought. Cambridge: University of Cambridge Press, Forthcoming.

Greenidge, A.H.J. A Handbook of Greek Constitutional History. London: Macmillan and Co. Limited. 1911.

Grant, George. Time as History. Toronto: University of Toronto Press, 1995.

Gray, John. Hayek on Liberty. Oxford: Basil Blackwell, 1984.

Green, Donal P. and Shapiro, Ian. Pathologies of Rational Choice Theory, A Critique of Applications in Political Science. New Haven: Yale University Press, 1994.

Greenidge, A. H. J. A Handbook of Greek Constitutional History. London: Macmillan and Co., 1911.

Greif, Avner. "Cliometrics after 40 years." The American Economic Review 87, No. 2 (May 1997): 400-403.

Griswold, Charles L. Adam Smith and the Virtues of Enlightenment. Cambridge: Cambridge University Press, 1999.

Hamilton, Alexander, Madison, James and Jay, John. The Federalist Papers. New York: New American Library, 1961.

Hansen, Phillip. Hannah Arendt, Politics, History and Citizenship. Standford: Standford University Press, 1993.

Hayek, Friedrich A. The Constitution of Liberty. Chicago: The University of Chicago Press, 1972.

Hayek, Friedrich A. Law, Legislation and Liberty, Volume 3: The Political Order of a Free People. Chicago: The University of Chicago Press, 1979.

Heidegger, Martin. Being and Time. San Francisco: Harper San Francisco, 1962.

Hobbes. Leviathan. Indianapolis: Hackett, 1994.

Honig, Bonnie (ed.). Feminist Interpretations of Hannah Arendt. University Park: The Pennsylvania State University Press, 1995.

Horowitz, David. The Morality of Spending: Attitudes toward the Consumer Society in America, 1875-1940. Baltimore: The John Hopkins University Press, 1985. 
Huber, Evelyne and Dion, Michelle. "Revolution or contribution? Rational choice approaches in the study of Latin American politics." Latin American Politics and Society 44, No. 3 (Fall 2002): 1-28.

Hutcheson, Francis. An Inquiry into the Original of our Ideas of Beauty and Virtue, Volume 1. Hildesheim: Georg Olms Verlagsbuchhandlung, 1971.

Johnson, David B. Public Choice, An Introduction to the New Political Economy. Mountain View: Bristlecones Books, 1991.

Kambouchner, Denis (ed.). Notions de Philosophie, III. Paris: Gallimard, 1995.

Keynes, John M. Essays in Biography. London: Macmillan, 1933.

Kateb, George. Hannah Arendt, Politics, Conscience, Evil. Totowa, New Jersey: Rowman \& Allanheld, 1984.

Khan, Joel S. "Towards an History of the Critique of Economism: The Nineteeth-Century German Origins of the Ethnographer's Dilemma." Man, New Series 25, No. 2 (June 1990): 230-249.

Kojève, Alexandre. Introduction à la lecture de Hegel. Paris: Gallimard, 1947.

Kramnick, Isaac. Bolingbroke and his Circle, The Politics of Nostalgia in the Age of Walpole. Cambridge, Massachusetts: Harvard University Press, 1968.

Larner, Wendy. "Neo-liberalism: Policy, Ideology, Governmentality." Studies in Political Economy 63 (Automn 2000): 5-25.

Lazear, Edward P. "Economic Imperialism." The Quarterly Journals of Economics 115, No. 1(February 2000): 99-146.

Lemke, Thomas. "The Birth of Bio-Politics - Michel Foucault's Lecture at the Collège de France on Neo-Liberal Governmentality." Economy and Society 30, No. 2 (2001): 190207.

Lévy, Jean-Phillippe. The Economic Life of the Ancient World. Trans. John G. Biram. Chicago: The University of Chicago Press, 1967.

Lindgren, Ralph J. The Social Philosophy of Adam Smith. The Hague: Martinus Nijhoff, 1973.

Little, Daniel. "Rational-Choice Models and Asian Studies." The Journal of Asian Studies 50, No. 1 (February 1991): 35-52.

Mandeville, Bernard. The Fable of the Bees. Oxford: F. B. Kaye, 1924. 
Marx, Karl. The Communist Manifesto. New York: W. W. Norton \& Company, 1988.

Mayer, Robert N. The Consumer Movement: Guardians of the Market-Place. Boston: Twayne Publishers, 1989.

McCloskey, Donald N. "The Achievements of the Cliometric School." The Journal of Economic History 38, No. 1 (March 1978): 13-28.

McNamara, Peter. Political Economy and Statesmanship, Smith, Hamilton, and the Foundation of the Commercial Republic. Dekalb: Northern Illinois University Press, 1998.

Miller, Peter and Rose, Nikolas. "Governing economic life." Economy and Society 19, No. 1 (1990): 1-31.

Miller, Toby. The Well-Tempered Self: Citizenship, Culture, and the Postmodern Subject. Baltimore: Johns Hopkins University Press, 1993.

Moldofsky, Naomie (ed.). ORDER-With or Without Design? London: The Centre for Research into Communist Economies, 1989.

Montes, Leonidas. "Notes on Das Adam Smith Problem." Journal of Economic Thought 25, No. 1 (2003): 63-90.

Morrow, Glenn R. The Ethical and Economic Theories of Adam Smith. New York: Augustus M. Kelley Publishers, 1969.

Murray, Oswyn and Price, Simon (eds.). The Greek City, From Homer to Alexander. Oxford: Clarendon Press, 1990.

Myers, M. L. The Soul of Modern Economic Man: Ideas of Self-Interest, Thomas Hobbes to Adam Smith. Chicago: University of Chicago Press, 1983.

Neiman, Max and Stambough, Stephen J. "Rational choice theory and the evaluation of public policy." Policy Studies Journal 26, No. 3 (September 1998): 449-465.

Nelson, Robert H. Economics as Religion, from Samuelson to Chicago and Beyond. University Park: The Pennsylvania State University, 2001.

Nishiyama, Chiaki and Leube, Kurt R. The Essence of Hayek. Stanford: Hoover Institution Press, 1984.

North, Douglass C. and Thomas, Robert P. The Rise of the Western World, A New Economic History. Cambridge: Cambridge University Press, 1973.

O’Brien, G. An Essay on Medieval Economic Teaching. New York: Burt Franklin, 1920. 
Owen, David (ed.). Sociology after Postmodernism. London: Sage, 1997.

Piettre, André. Histoire de la pensée économique et analyse des théories contemporaines. Paris: Dalloz, 1966.

Plato. The Laws. Trans. Thomas L. Pangle. Chicago, University of Chicago Press, 1988.

Plato. The Republic. Trans. Alan Bloom, second edition. New York: Basic Books, 1968.

Polanyi, Karl. The Great Transformation, The Political and Economic Origins of Our Time. Boston: Beacon Press, 2001.

Polanyi, Karl and others. Trade and Market in the Early Empires, Economies in History and Theory. New York: The Free Press, 1957.

Pope, Alexander and Mack, Maynard. An Essay on Man. London: Methuen and Co. Ltd., 1950.

Rahe, Paul A. Republics Ancient and Moderns, Classical Republicanism and the American Revolution. Chapel Hill: The University of North Carolina Press, 1992.

Rayack, Elton. Not so Free to Choose: The Political Economy of Milton Friedman and Ronald Reagan. New York: Praeger, 1987.

Robertson, John (ed.). Characteristics. Indianapolis: Bobbs-Merill, 1964.

Rousseau, Discours sur l'économie politique, Projet de constitution pour la Corse, Considérations sur le gouvernement de Pologne. Paris: Flammarion, 1990.

Rostovtzeff, M. The Social \& Economic History of the Hellenistic World, Volume II. Oxford: Claredon Press, 1986.

Samuels, Warren J. (ed.). The Chicago School of Political Economy. East Lansing: Michigan State University, 1976.

Schmitt, Carl. The Concept of the Political. Trans. George Schwab. Chicago: The University of Chicago Press, 1996.

Self, Peter. Government by the Market? The Politics of Public Choice. Boulder: Westview Press, 1993.

Smith, Adam. The Theory of Moral Sentiments. New York: Prometheus Books, 2000.

Smith, Adam. The Wealth of Nations. New York: Bantam Dell, 2003.

Spiegel, H. W. The Growth of Economic Thought. Durham: Duke University Press, 1991. 
Stigler, George J. Chicago Studies in Political Economy. Chicago: The University of Chicago Press, 1988.

Stigler, George J. The Economist as Preacher, and Other Essays. Chicago: The University of Chicago Press, 1982.

Strauss, Leo and others. De la tyrannie; suivi de, Mise au point; ainsi que de la Correspondance Leo Strauss-Alexandre Kojève (1932-1965). Paris: Gallimard, 1997.

Strong, Tracy B. The Idea of Political Theory, Reflections on the Self in Political Time and Space. Notre Dame: University of Notre Dame Press, 1990.

Temin, Peter (ed.). New Economic History. Baltimore: Penguin Books, 1973.

Teixeira, Herminio Meireles. The Sovereignty of Governed Populations: An Inquiry into the Displacement of the Common Good in Modern Political Thought. PhD diss. Ottawa: Carleton University, 2002.

Thucydides and Woodruff, P. On justice, power, and human nature: the essence of Thucydides' History of the Peloponnesian War. Indianapolis: Hackett, 1993.

Trever, A. A. A History of Greek Economic Thought. Chicago: The University of Chicago Press, 1916.

Tribe, Keith. Governing Economy: The Reformation of German Economic Discourse, 1750-1840. Cambridge: Cambridge University Press, 1988.

Tsebelis, George. Nested Games, Rational Choice in Comparative Politics. Berkeley: University of California Press, 1990.

Ullman, Walter. Principles of Government and Politics in the Middle Ages. London: Methuen \& Co, 1961.

Valverde, Mariana. "Despotism and ethical governance." Economy and Society 25, No. 3 (1996): 357-372.

Villa, Dana Richard. Arendt and Heidegger: The Fate of the Political. Princeton, N.J.: Princeton University Press, 1996.

Villa, Dana Richard. Socratic Citizenship. Princeton: Princeton University Press, 2001.

Waligorski, Conrad P. The Political Theory of Conservative Economists. Lawrence: The University press of Kansas, 1990. 
Whaples, Robert. "A Quantitative History of the Journal of Economic History and the Cliometric Revolution." The Journal of Economic History 51, No. 2 (June 2001): 289301.

Woolf, Virginia. A Room of One's Own. Peterborough: Broadview Press, 2001.

Wolin, Sheldon S. Politics and Vision, Continuity and Innovation in Western Political Thought. Boston: Little, Brown and Company, 1960.

Wood, Diana. Medieval Economic Thought. Cambridge: Cambridge University Press, 2002.

Xenophon and Pomeroy, S.B. Oeconomicus: a social and historical commentary. Oxford: Oxford University Press, 1994.

Zunz, Olivier and Kahan, Alan S. The Toqueville Reader, A Life in Letters and Politics. Oxford: Blackwell Publishers, 2002. 